\title{
Agustín modelo y maestro de oración
}

\section{INTRODUCCIÓN}

El título contiene fundamentalmente dos cosas: un personaje: Agustín. Una temática: modelo y maestro de oración.

Agustín es un hombre de extraordinaria relevancia. Una personalidad totalmente religiosa. Un hombre enamorado de Dios. Un pensador genial. Por todo ello, Agustín ha tenido una influencia decisiva en la configuración de Europa y, a través de ésta, en Occidente. «Padre espiritual de Occidente se ha llamada a san Agustín por la influencia universal que ha desplegado en la espiritualidad cristiana de Europa. Ascetas y místicos le han mirado siempre con singular devoción, porque, además de una doctrina, ofrece una vida ejemplar de intimidad con Dios» ${ }^{1}$.

Todo esto es cierto. Cuando se trata de ponderar tanto la personalidad religiosa de Agustín como la influencia de su magisterio parece que faltan los epitetos. Siempre queda uno con la impresión de no llegar a reflejar la realidad. Ello, no obstante, no puede ni debe hacernos olvidar que Agustín es un hombre de una época muy concreta. Una época que tiene un entorno cultural muy definido, especialmente en el ámbito religioso. Por más que se quieran buscar y ver afinidades en este campo con nuestro mundo las diferencias son abismales. Tendremos oportunidad de verlo a lo largo de este estudio. Decía que Agustín vive en un ámbito cultural religioso muy específico. Y por muy genial que sea una persona no se puede sustraer al entorno cultural que la envuelve, aunque ciertas intuiciones puedan traspasarlo. Por olvidar este sencillo acto de observación elemental, se pone en ocasiones en boca de Agustín o se le atribuyen ideas que ni siquiera pudieron pasar por su mente. Hay, pues, que contar con el entorno cultural en que se mueve Agustín, si se quiere ser objetivos. 111.

1. CAPÁnAGA, V., Introducción general a las obras de San Agustín, BAC, Madrid 1946, 
El tema, aquí a tratar, la oración, es también un tema de una complejidad nada deleznable. Un tema, por lo demás, sometido a una revisión profunda. Lo cual no acontecía en tiempos de Agustín. Para un creyente de entonces la oración, en cualquiera de sus formas, era algo evidente y estaba llena de coherencia. Y lo era así porque el tema de Dios tenía también suficiente entidad y claridad. El Dios de la Biblia, visto a través de unas categorías filosóficas concretas, aparecía como «excelentísimo, buenísimo, poderosísimo, todopoderosísimo, misericordiosísimo y justísimo, ocultísimo y presentísimo, hermosísimo y fortísimo, estable e inasible, inmutable que todo lo muda, nunca nuevo y nunca viejo, renovador de todas las cosas»> ${ }^{2}$. Con él habla Agustín como si le tuviera presente, como si le tocara y le sintiera, como una realidad a la que no se puede ignorar. «La resultante es, Señor, que yo no tendría ser, que no existiría en absoluto, si tú no estuvieras en mí.

¿No sería más apropiado decir que yo no existiría, si no estuviera en ti, de quien, por quien y en quien tienen ser todas las cosas? También es así, Señor, también es así. Y si ya estoy en ti, ¿a qué lugar te emplazo, cuando te invoco? ¿O de qué lugar vienes, cuando vienes a mí? Porque, fuera del cielo y la tierra, ¿a qué rincón voy a retirarme para que desde él venga a mí el Señor que dijo: 'yo colmo los cielos y la tierra' $\gg{ }^{3}$.

Al escuchar las palabras de Agustín se siente sobrevolar en el entorno una seguridad sin grietas, absoluta. El tema de Dios aparece y se impone con claridad. Y éste era ciertamente el clima que envolvía el ambiente del tiempo de Agustín. Para un creyente de entonces el tema de Dios resultaba algo plenamente claro. «El hombre que encontramos en la Biblia, en los escritos patrísticos y en los teólogos agustinianos del medioevo, era una persona que lo contemplaba todo y lo valoraba todo directamente desde la causa primera y última: desde Dios» ${ }^{4}$.

Mas ¿qué sucede en nuestro tiempo? ¿Cómo se ve y está el problema de Dios en nuestra época? Unas incisivas palabras de Hans Küng nos lo dicen: «¿Existe Dios? Y por extensión: ¿Quién es Dios? A ambas preguntas quiere este libro dar una respuesta y fundamentarla. Quiere tomar en serio el interrogante, pero no quedarse ahí. ¿Sí a Dios? Hace mucho tiempo que para muchos cristianos ya no es evidente. ¿No a Dios? Para muchos no creyentes tampoco lo es...

Y aun cuando Dios existiera: ¿sería personal o impersonal? ¿No resultaría ingenuidad lo primero y abstracción lo segundo? ¿O tal vez habría que preferir la sabiduría del Oriente? ¿El callar del budismo ante el absoluto sin nom-

2. San Agustín, Conf. Lib. 1,4,4. Sigo la traducción del P. José Cosgaya.

3. ID., o.c., $1,2,2$.

4. Schillebeeckx, E., Dios futuro del hombre, Sígueme, Salamanca 1970, 58. 


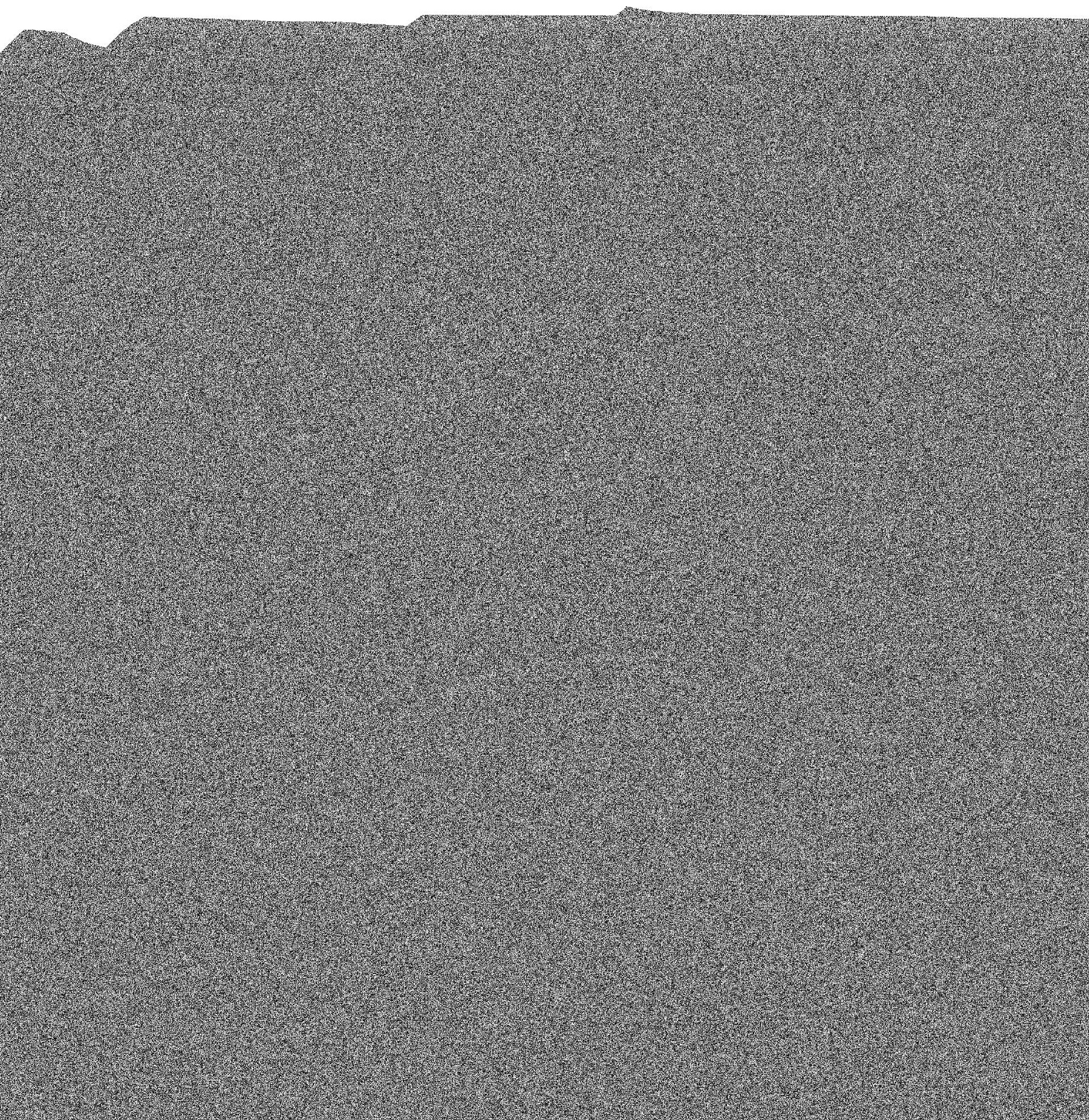


bre en su esencia y proceso? Dos grandes corrientes de ideas, pero hornagueadas por la propia experiencia, influyen en la antropología de san Agustín, como en la de cultura occidental: la corriente bíblica y paulina del hombre, imagen de Dios y ser caído en la culpa, y la corriente griega del homo rationalis, o animal movido por un verbo interior en que se cifra toda su alteza y dignidad» ${ }^{8}$.

La antropología agustiniana, teológicamente considerada, es hasta cierto punto bíblica. Y digo hasta cierto punto, porque la influencia filosófica griega le impide contemplar al hombre unitariamente tal y como le había visto siempre la corriente hebrea. Desde esta perspectiva, la antropología agustiniana es dualista como lo fue la antropología griega. Lo veremos esto más adelante. Por ahora, pongamos los ojos en la antropología agustiniana desde la perspectiva teológica. El hombre es, según él mensaje bíblico, imagen y semejanza de Dios, llamado a vivir su relación con Dios en un clima de amistad y cercanía. Tal situación obedece a una gracia que supera las exigencias de la misma condición humana. Y se traduce en la concesión de la justicia original, don sobrenatural, y en la ausencia de la muerte y el equilibrio de la concupiscencia, dones preternaturales. Todo esto se rompe con la desobediencia del primer hombre. «Con su pecado perdió la justicia y la santidad verdadera, por la cual se deformó y se deslució la imagen de Dios, que vuelve a recibirse con la renovación espiritual» ${ }^{9}$.

El pecado de Adán y sus consecuencias afectan no sólo a su ejecutor, sino también a todos los descendientes. Por ello es llamado pecado original. «Es aquél único pecado, que entró por un solo hombre en el mundo y pasó a todos los hombres, de suerte que hasta los párvulos deben ser también bautizados» ${ }^{10}$. «Así como en el pecado de Adán son inseparables tres cosas: la mala voluntad, primera causa de todo; la privación de la gracia y la pérdida de la integridad o privilegios consecutivos a la justicia original, así en la herencia compleja de aquel pecado se entrañan tres cosas: un reato de culpa por la conexión seminal de todo hijo de Adán con su padre, una privación de la gracia y justicia primitiva y una rebelión y desmandamiento de los instintos carnales en pena de la desobediencia al Creador. No se puede suprimir ninguno de estos elementos sin desnaturalizar el pecado hereditario de los hombres. La rebelión de la concupiscencia es una parte del desorden íntimo producido por el primer desorden humano" ${ }^{11}$.

8. CAPÁNAGA, V., Introducción general a las obras de San Agustín, BAC, Madrid 1946, 57.

9. San Agustín, De Trinitate, Lib. 14,16,22; PL 42,1053.

10. SAN AGUSTIN, Enchiridium, 45.

11. CAPÁNAGA, V., Introducción general al tomo VI de las obras de San Agustín, BAC, Madrid 1949, 97. 
El tema de la gracia adquiere relieve peculiar en esta antropología. Agustín es por antonomasia, el doctor de la gracia. Siguiendo a Pablo, otro gran convertido, Agustín hace suya la sentencia del Apóstol: ¿Qué tienes que no hayas recibido? Y, si lo has recibido, ¿a qué gloriarte cual si no lo hubieras recibido». (1 Cor 4,7). Según esto todo lo que hay de bueno en el hombre es don de Dios, es gracia.

Al recuerdo de esta frase y de otros pasajes bíblicos, Agustín construye su doctrina de la gracia. Doctrina que sufre algunos cambios y que llega a su formulación definitiva en la lucha contra el pelagianismo y el semipelagianismo. En un principio Agustín atribuye al querer humano el creer y el querer. "Aun no había ahondado en el valor gratuito y sobrenatural de la fe, considerándola como un fruto de los esfuerzos e investigaciones naturales del hombre: nostrum est enim credere et velle» ${ }^{12}$. Los dos extremos, difícilmente articulables, de toda esta doctrina son: gracia eficaz y envolvente, por un lado; libre albedrío, por otro. Agustín mantiene siempre esta postura y multiplica las fórmulas aparentemente afortunadas para mostrar su postura. Digo aparentemente afortunadas, porque, cuando se intenta ver la coherencia entre los dos extremos, gracia y libertad, surgen en el horizonte múltiples y graves interrogantes. Cosa, por lo demás nada extraña, pues ya aconteció en tiempos del mismo Agustín y en los años posteriores a su muerte. «No faltan puntos en la doctrina agustiniana que despertaron viva oposición entre algunos contemporáneos, sobre todo monjes. El de la predestinación fue calificado, a pesar de su origen paulino, de nuevo y peligroso, fomentador del fatalismo y pasividad. El Commonitorium de Vicente de Lerins, que pasa por ser una joya de la antigua literatura eclesiástica, compuesto con el propósito de esclarecer el desarrollo dogmático del cristianismo, fue un disparo contra el obispo de Hipona. Se interpretaba la gracia eficaz como una fuerza violenta e irresistible que produce en nosotros la voluntad de obrar de una manera mecánica, violando los derechos del libre albedrío»" ${ }^{13}$.

Agustín recoge las críticas que se formulan contra su doctrina sobre la gracia. Y no se arredra ante ellas. Al contrario, se mantiene firme, apoyando su pensamiento en la doctrina revelada. Para él gracia y libre albedrío son perfectamente compaginables. Teóricamente, al menos, no parece existir duda alguna. La enseñanza bíblica al respecto parece ser también suficientemente clara. Todo es gracia. Y esto no es posible, si el hombre puede atribuirse algo como consecuencia de su esfuerzo. Pero también, si no existe el libre albedrío, ¿cómo explicar el misterio de la salvación o de la condenación? «Llega la hora

12. ID., o.c., 23.

13. ID., o.c., 25 . 
en que todos los que estén en los sepulcros, oirán su voz (la del Hijo) y los que hayan hecho el bien resucitarán para la vida, y los que hayan hecho el mal, para la condenación» (Jn 5,28b-29). Sin la libertad humana esta discriminación no puede explicarse más que como un capricho divino impropio de Dios. La libertad humana es un elemento necesario, indispensable del plan salvífico.

Si teóricamente no se dan inconvenientes, no parece que suceda lo mismo a nivel práctico. La dificultad surge, cuando se trata de articular prácticamente los dos postulados: la necesidad de la gracia y la libertad. $O$, si se quiere mejor, las dificultades surgen, al reflexionar detenidamente sobre el tema. ¿Cómo se puede hablar de libertad, si todo es gracia? Y, si se acepta la libertad, ¿cómo puede-ser todo gracia? ¿Hasta qué punto la doctrina agustiniana de la gracia salva estas dificultades? ¿Cae Agustín en contradicción? ¿Estamos más bien ante el misterio? Seguramente que esto último envuelve toda esta temática. De todos modos, el hombre tiene derecho a plantearse cuestiones que le afectan de una manera tan directa. Y en ello Agustín fue enormemente sincero. Él propone lo que cree descubrir en la palabra de Dios. «La misericordia de Dios sola no basta, si no se añade el concurso de nuestra voluntad» ${ }^{14}$. «Con todo, de que sea cierto para Dios el orden de todas las cosas, no se sigue que nada haya en el arbitrio de la voluntad, porque también nuestras mismas voluntades están en el orden de las causas, que es cierto para Dios y se contienen en su presencia, ya que son causas de las acciones humanas. Y, por ende, el que conoce de antemano todas las causas de las cosas, no puede ignorar, sin duda, entre estas causas a nuestras voluntades, que, de antemano, supo que son causa de nuestras acciones» ${ }^{15}$. Según todo esto, Agustín no ve contradicción alguna entre su doctrina de la gracia, la presciencia de Dios y la existencia del libre albedrío.

Líneas atrás he formulado desde una perspectiva personal algunos interrogantes insoslayables ante la doctrina de Agustín acerca de la antropología teológica. La respuesta a los mismos no es nada fácil. Y preferí, por ello, quedarme en la línea del misterio, sin atreverme a cuestionar la solución agustiniana. Ahora quiero hacerme portavoz de las voces de nuestro tiempo. ¿Puede aceptarse hoy, químicamente pura, la antropología agustiniana? ¿Es articulable con la visión que hoy se tiene del hombre, incluso desde el punto de vista religioso? Creo con sinceridad que entre la visión agustiniana del hombre y la visión moderna del mismo se dan profundas diferencias. Por más que uno lo intenta no alcanza a ver que se dé en la visión agustiniana del hombre la autonomía frente a Dios que los antropólogos modernos reclaman. Autono-

14. San Agustin, De diver. quaest. ad Simpl. 1,q.2,12; PL 40,118.

15. San Agustín, De Civ. Dei, 5,9,3. 
mía, por lo demás, que ha quedado hasta cierto punto canonizada por el concilio Vaticano II. «En todo el mundo crece más y más el sentido de la autonomía y, al mismo tiempo, de la responsabilidad, lo cual tiene enorme importancia en pro de la madurez espiritual y moral del género humano. Esto se ve más claro, si fijamos la mirada en la unificación del mundo y en la tarea, que nos ha sido impuesta, de edificar un mundo mejor en la verdad y en la justicia. De esa manera somos testigos de que nace un nuevo humanismo en que el hombre queda definido principalmente por su responsabilidad hacia sus hermanos y hacia la historia» ${ }^{16}$. Hay aquí un lenguaje y un contenido ideológico de difícil armonización con el pensamiento agustiniano. En este nuevo humanismo no hay referencia explícita a Dios. Lo cual resultaría inconcebible en el pensamiento agustiniano. En la doctrina agustiniana del hombre todo huele a dependencia. No se alcanza a ver esa legítima autonomía del hombre frente a Dios, de la que se habla tanto a nivel eclesiástico como a nivel extraeclesial. $\mathrm{Ni}$ tampoco se alcanza a ver en la doctrina agustiniana la posibilidad de ese nuevo humanismo sin referencia directa a Dios. Todo esto no puede extrañar a nadie. Al fin y al cabo los tiempos no pasan inútilmente y el progreso no se cierra ni en una época determinada ni con un hombre concreto. No se hace justicia a Agustín, ni a nadie, cuando se les hace hablar un lenguaje y manejar unos conceptos impropios del tiempo que vivieron. El mundo ideológico de Agustín es un mundo totalmente divinizado. Y el hombre un hombre radicalmente infantilizado. Es fácil detectar la presencia de Dios en el cosmos y en la historia. El hombre se siente protegido por Dios en un mundo que lo envuelve y lo domina. El discurso teológico es el normal y envolvente, de forma que todos los demás aspectos, bien de la realidad o del hombre, siempre se miran a través de su prisma. Hoy el panorama es muy distinto. La teología ha perdido su hegemonía y de ella se han desgajado múltiples ámbitos del saber humano. Ello ha llevado a que el hombre adquiera cada vez mayor autonomía frente al tutelarismo religioso. Las huellas de Dios ya no aparecen con aquella nitidez que podían tener en tiempos pasados. «La teología, que pretende tomar al mismo Dios como objeto de su reflexión, se ve obligada en la actualidad a dar pruebas de modestia. Por todos lados, la ausencia de Dios se ha visto elevada, por así decirlo, a la dignidad de experiencia existencial» ${ }^{17}$. Mientras que, en cierto sentido, Dios se encuentra en retroceso en nuestro mundo, el hombre va adquiriendo mayor protagonismo. Muchas de las cosas que antes pedían una fundamentación divina, ahora se construyen sobre bases meramente humanas. Casi, casi está uno tentado a decir que el hombre ha crecido en perjuicio

16. VATICANO II, GS. 55.

17. Schillebeeckx, E., Dios y el hombre, Sígueme, Salamanca 1969, 33. 
de Dios. En verdad, la frase no es correcta, al menos en sentido profundo. Puede serlo, si la entendemos como protesta contra ciertas imágenes de Dios. Por todo ello, la antropología teológica agustiniana, marcada por un dominio absoluto de Dios sobre el hombre, difícilmente puede ser acogida en nuestro mundo, en que se prima una justa autonomía del hombre. El «fenómeno histórico-cultural de la secularización tiene directas consecuencias para el hombre en su relación con Dios. El mundo, descubierto en su propio juego de leyes y dominado por el hombre, pierde su carácter sagrado y deja de ser 'santo' en lo más íntimo. Hacer que este mundo sea mundo, significa también hacer que Dios sea Dios. A Dios no se le considera ya como alguien que interviene directamente en nuestro mundo y dirige inmediatamente todos los acontecimientos.

El hombre autónomo se sustrae a un legislador supraterreno que, a través de la iglesia, se inmiscuya directamente en todos los campos de la vida. $Y$, en una especie de perspectiva del futuro, este hombre no considera ya el 'valle de lágrimas de la tierra' como una 'antesala' de la 'felicidad celestial', en donde ya no se daría esta vida, sino otra vida que habría de venir más tarde.

En la nueva imagen del hombre y del mundo que ahora se ofrece, no puede ya funcionar una imagen simplista y tradicional de Dios. Se discute la posibilidad misma de una imagen de Dios» ${ }^{18}$.

Hechas estas matizaciones diferenciales entre antropología teológica agustiniana y antropología moderna, es preciso considerar el mismo tema desde la perspectiva filosófica. Aunque el punto más significativo está seguramente en lo anteriormente dicho, lo que se va a decir tienen también su importancia. Al fin y al cabo el punto de intersección es el mismo: el hombre. Filosóficamente hablando, la antropología agustiniana es helénica. Y, dentro del helenismo, es de tendencia platónica, sin llegar en ello a los extremos del Platonismo, tanto en la preexistencia de las almas como en su unión accidental con el cuerpo. El hombre es el resultado de dos elementos: alma y cuerpo. Estamos, pues, ante una antropología dualista. $Y$, aunque se hable de unión sustancial, de no fácil comprensión, si se tiene en cuenta la condición de ambos elementos, resulta difícil superar el dualismo. El alma es en la antropología griega, en general, y en la agustiniana, en particular, el elemento principal. Casi, casi me atrevo a decir el elemento sustancial. «El alma da al cuerpo su ser específico de organismo humano, así como el desarrollo vital y la hermosura que le compete. Y por eso goza de una preeminencia y superioridad ontológica con respecto al cuerpo: 'el alma es cosa espiritual, incorpórea y próxi-

18. Concilio Pastoral Holandes, Religiosos en una sociedad nueva, Sígueme, Salamanca $1971,23$. 
ma a la sustancia de Dios» ${ }^{19}$. El cuerpo es el consorte pobre de este matrimonio, cuando no llega a ser el consorte malo, que hay que mantener a raya con una ascética de castigo. Tan influyente ha sido esta antropología dualista en la espiritualidad de Occidente que ha llevado, como de la mano, a un desprecio del cuerpo y de todo lo material. Tradicionalmente se hablaba de salvar el alma. Incluso, al hablar de hombre, se entendía frecuentemente y solamente como alma.

Hay aquí, no quererlo reconocer es cerrar los ojos a la realidad, una visión depauperada del cuerpo y, por ósmosis, de todo lo material. Y en ello radica la oposición que hoy existe contra la antropología griega. El desprecio del cuerpo y del mundo son hoy vistas no sólo con antipatía, sino también como erróneas. «No debe el hombre, por tanto, despreciar la vida corporal, sino que, por el contrario, debe tener por bueno y honrar a su propio cuerpo" ${ }^{20}$. Así habla el concilio de nuestro tiempo. Y, desde luego, hay que reconocer que, con sus palabras, ha aplicado la piqueta a un edificio espiritual construido a lo largo de muchos siglos. Agustín ha sido llamado Padre espiritual de Occidente ${ }^{21}$. Vistas las características de dicha espiritualidad, al tiempo que el cambio producido en nuestro mundo acerca del tema, no queda otro camino que llevar a cabo una casi exhaustiva labor de interpretación, si queremos ser fieles a nuestro tiempo y queremos también hacer justicia a Agustín.

Las diferencias, bastante pronunciadas, entre el mundo ideológico de Agustín y nuestro mundo por lo que respecta al tema de Dios y del hombre influyen de forma muy directa e intensa en el tema de la oración. Para Agustín la oración es un ejercicio del todo conforme a su teología y a su antropología. Para el hombre de hoy, y ello en fuerza de su nueva visión de Dios y del hombre, la oración ya no aparece tan clara y evidente. La crisis de lo contemplativo ha sido y sigue siendo una característica muy significativa de nuestro tiempo.

La crisis nace, en primer lugar, como protesta contra una espiritualidad mal enfocada y con resultados, a veces, negativos. Mal enfocada, porque el acento se ponía sólo o de forma prioritaria en lo puramente espiritual, marginando e incluso despreciando lo material. Con resultados negativos, porque algunas, ¿muchas?, personas devotas hasta casi el paroxismo no han brillado precisamente por aquello que es lo constituvo del seguidor de Jesús: el amor a los demás. Antes bien, se les ha visto egoístas, exigentes y con criterios hasta

19. CAPÁNAGA, V., Introducción general a las obras de San Agustín, BAC, Madrid 1946, 61.

20. Concilio Vaticano II, GS. 14a.

21. Cf. CAPÁnAGA, V., Introducción general a las obras de San Agustín, BAC, Madrid $1946,111$. 
mezquinos. «Siempre se ha hecho oración en la iglesia. Siempre se ha insistido en este asunto como una cuestión de vida o muerte para quienes pretendían tomar en serio la vida cristiana. $\mathrm{Y}$, sin embargo, ahí están los resultados: gente muy piadosa, muy fiel a sus prácticas espirituales, muy entregada a hacer su oración cada día con la mayor generosidad del mundo, pero gente, al mismo tiempo, que ha aportado muy poco a hacer que este mundo sea menos inhumano» ${ }^{22}$.

Tras constatar de forma sucinta los motivos principales de la crisis de lo contemplativo, es preciso desarrollar un poco más extensamente la primera de las causas aducidas: la espiritualidad mal enfocada. En ella radica de forma prioritaria la crisis de lo contemplativo. Dicha crisis se venía gestando desde bastante atrás. Se puede decir que su comienzo se inicia aún antes del nacimiento de la filosofía moderna, aunque es aquí donde va tomando cuerpo. Adquiere intensidad fuerte a lo largo del siglo XIX y explosiona en la primera mitad del siglo XX. «Algo iba a cambiar en el siglo XX. El diálogo de la Iglesia con el mundo moderno dio entrada progresiva en los cristianos más abiertos a la escucha atenta a las tres clásicas oposiciones a la oración: Nietzsche (no puede existir el Absoluto, si queremos mantener la libertad); Freud (la oración no es más que una ilusión compensatoria); Marx (la oración se disuelve en una evasión vital).

La parte de verdad encerrada en estas acusaciones y el descubrimiento por parte de los cristianos de la dignidad interior de las cosas y de los valores del compromiso y del trabajo prepararon y provocaron la, quizá, primera contestación ideológica en las élites del cristianismo. Las capas inferiores no se enteraban todavía de este cambio. Pero algo comenzaba a moverse» ${ }^{23}$.

Hacia los años sesenta la crisis de lo contemplativo y, por ende, de la oración adquiere su cota más alta. Estamos en la época de la teología de la muerte de Dios y de la ciudad secular. El fenómeno de la secularización mina por entonces ciertas imágenes de Dios y del hombre. Por refracción se proyectan al tema de la oración. Los avances científicos y el estilo tecnicista adoptado por el hombre de nuestro tiempo contribuyen a que el mismo hombre supere la imagen de ser un ente inerme ante Dios. Parece ser que el hombre goza de una autonomía que le desgaja, en parte, de Dios. Lógicamente este nuevo clima no puede por menos de afectar al tema de la oración, tan profundamente vinculada a la realidad divina. «Este fenómeno histórico-cultural de la secularización tiene directas consecuencias para el hombre en su relación con Dios. El mundo, descubierto en su propio juego de leyes y dominado por el hombre, pierde

22. CAStillo, J.M., La alternativa cristiana, Sígueme, Salamanca 1978, 213.

23. Guerra, A., Oración. En Conceptos fundamentales de Pastoral, Ed. Cristiandad, Madrid 1983,665 . 
su carácter sagrado y deja de ser 'santo' en lo más íntimo. Hacer que este mundo sea 'mundo', significa hacer que Dios sea 'Dios', es decir, el nomundano, el Trascendente. A Dios no se le considera ya como alguien que interviene directamente en nuestro mundo y dirige inmediatamente todos los acontecimientos humanos» ${ }^{24}$.

Es lógico, al menos hasta cierto punto, que en un marco cultural, como el que dibujan las palabras anteriores, el tema de la oración sufriera diversas convulsiones. Todo ello se tradujo, como primera instancia, en abandono de la oración $\mathrm{o}$, al menos, menos dedicación de tiempo a su ejercicio. «Se ora menos», decía Pablo VI, reflejando un clima general ${ }^{25}$. Se alzaron entonces profundos y graves interrogantes sobre el tema de la oración. ¿Qué era, en el fondo, orar? ¿Por qué las personas, al menos, algunas, que se dedicaban a la oración estaban tan poco comprometidas en la transformación de una sociedad a todas luces injusta? ¿Para qué servía una oración que no terminaba en un compromiso temporal? Este clima se agravaba desde otras perspectivas. Religiosos, religiosas y sacerdotes, normalmente hombres y mujeres dedicados con asiduidad a la oración, abandonaban, en ocasiones con desilusión y aburridos, su estilo de vida. Bastantes confesaban que la oración, practicada a lo largo de tantos años, no les había servido de nada, antes, por el contrario, había contribuido a crear vacío e insatisfacción.

La situación, antes retratada, encuentra su revulsivo relativamente pronto. Ello acontece hacia los años setenta. «El homo faber, centrado en la acción, típico de la década anterior, dejaba paso al homo ludens, bien descrito en Juan Salvador Gaviota ${ }^{26}$, libro revelación de esos años: esta gaviota, que es el hombre de los años setenta, busca más volar que comer, prefiere lo espiritual a lo material y consumista. Surgen, además, en esos años una serie de teologías (de la fiesta, del juego, del humor, etc.), que parecen, al menos, inicialmente, más afectas a la oración contemplativa, a la que siempre se ha tenido por oración. Más aún, varios teólogos, que en la década anterior habían mantenido un sospechoso silencio sobre la oración (Moltmann, J. B. Metz, H. Cox, por ejemplo) sorprendieron en los años setenta con ciertos encuadres y páginas en los que la oración era una realidad vital e indispensable» ${ }^{27}$.

Los movimientos transformativos nunca vienen motivados, por lo menos de forma principal, por corrientes simplemente ideológicas. Obedecen más a la praxis que a la teoría. Es lo que acontece en el campo de la oración. En la

24. Concilio Pastoral Holandé, Religiosos en una sociedad nueva, Sígueme, Salamanca $1971,23$.

25. PABlo VI, Audiencia del 14.VIII.1969.

26. BACH, R., Juan Salvador Gaviota, Barcelona 1975.

27. Guerra, A., Oración. Conceptos fundamentales de Pastoral, Ed. Cristiandad, Madrid 1983, 666-667. 
década de los sententa surgen una serie de movimientos prácticos oracionales que, junto a una especie de embrujo por lo oriental típicamente contemplativo, han servido para poner de nuevo en el candelero el tema de la oración, como expresión cualificada y primaria de lo religioso. No hay que olvidar que en dicha revalorización ha tenido también su parte la profunda decepción producida en torno a los valores de la técnica. Hoy nadie piensa que la técnica sea sin más la panacea para todos los problemas humanos y que sobre ella deba alzarse el edificio de la felicidad del hombre. La técnica puede llenar tal vez las aspiraciones más normales del hombre, pero deja frecuentemente sin llenar las aspiraciones más típicamente humanas. «La humanidad, qué duda cabe, ha perdido algunas esperanzas. En los pasados años sesenta, ciertamente, aquella fe que en los dos últimos siglos había reemplazado en gran parte la fe en un verdadero Dios volvió a alcanzar un -último- punto culminante, tanto en Oriente como en Occidene. La fe en el eterno, inconmensurable, omnisciente y omnipotente ¡Dios Progreso! Pero hoy en día, ¿quién cree aún tan ingenuamente en la humanidad del hombre por revolución político social? ¿Quién no abriga alguna duda sobre la humanidad del hombre por evolución tecnológica? Es indiscutible: el 'capitalismo', la fe en la ciencia, la tecnocracia, lo mismo que el 'socialismo' el marxismo y la revolución, para muchas personas de Oriente y de Occidente se presentan como ideologías que han perdido su importancia, por mucho que ambas se hayan amalgamado en los últimos decenios» ${ }^{28}$.

Si es evidente una recuperación de la praxis oracional en los últimos años, y ello en fuerza del desencanto producido por las ambigüedades que conlleva la técnica, no por ello están resueltos todos los problemas que suscita la oración. $Y$, desde luego, la nueva situación no puede producir el engaño de que es preciso volver sin más al pasado. Hay cosas que siempre quedan como conquista definitiva tras la purificación de ciertos fenómenos culturales. Después del fenómeno de la secularización ya no se puede imaginar a Dios como prepotente y al hombre como endeble e infantil. El hombre tiene en sí y por sí la capacidad de poder organizar al mundo de forma más humana. Y ello debe hacerlo tanto si es creyente como si no lo es. «También el hombre autónomo considera el respeto y el amor hacia la persona humana como el valor supremo. Este respeto y amor hacen que todo lo demás sea relativo»" ${ }^{29}$.

He hablado de recuperación de la praxis oracional en los últimos años, es decir, a partir de los años setenta. Alguien pudiera desmentir tal afirmación en base a la estadística. Y esto es verdad. El número dé indiferentes en el campo

28. KuenG, H., ¿Vida eterna?, Ed. Cristiandad, Madrid 1983, 300.

29. CONCILIO PASTORAl Holandés, Religiosos en una sociedad nueva, Sígueme, Salamanca 1971, 22. 
religioso va en aumento ${ }^{30}$. Si he dicho eso es sencillamente teniendo en cuenta que el fenómeno acontece a nivel de grupos concretos, especialmente jóvenes. El fenómeno acontece en una escala reducida y no se pueden echar las campanas al vuelo. La increencia sigue avanzando, como lo demuestran las estadísticas ${ }^{31}$. Y en su torbellino arrastra la oración. Augusto Guerra, especialista en el tema de la oración, cree reflejar su problemática de la forma siguiente:

«a) Crisis: palabra ya para algunos manida, pero de indudable valor, si no la hacemos sinónima de algo que va mal, de algo negativo. Para nosotros, la palabra crisis significa aquí un 'momento decisivo o difícil de un negocio grave'. Con ello se indican dos cosas: que la oración es una realidad tan importante que sobre ella puede recaer la categoría de crisis, y que el momento actual es particularmente delicado.

b) Contraste: es una palabra más genérica, pero puede ser sociológicamente interesante. Apunta a ese aparente desconcierto que manifiesta el que unos hayan huido o continúen huyendo de la oración, mientras otros vuelven a ella o incluso la hambrean, sin que antes hubiera significado nada particular para ellos.

c) Ambigüedad: muchos retornos a la oración parecen ambiguos como irracionales parecieron antes las huidas. ' $\mathrm{La}$ sospecha de ambigüedad recae sobre unos, porque vienen a la oración desde el hastío y el cansancio; sobre otros, porque vuelven desde la desilución con que se les pagó un esfuerzo noble y leal en la lucha; sobre los terceros, porque se embriagan de palmas y risas gozosas en un mundo de estupor y lágrimas; sobre los últimos, porque se acercan ensimismados al ombligo del mundo sin que aparezca Cristo como camino' ${ }^{32}$. Personalmente creo que la palabra ambigüedad es la que mejor indica qué es lo que sucede hoy con la oración»" ${ }^{33}$.

Como se desprende de este sustancioso texto, el tema de la oración está cargado de problemas graves y difíciles. Lo cual indica la delicadeza del tema y, al mismo tiempo, expresa la seriedad con que hay que tratarlo. Hay que eliminar, de entrada, las soluciones fáciles. En el apartado siguiente intentaré describir y dibujar el rostro de la verdadera oración cristiana. Sólo así es posible purificarla de tantas y tantas adherencias que la han desfigurado profundamente, hasta convertirla, en ocasiones, en origen y fuente de posturas netamente antievangélicas. La oración cristiana por ser precisamente encuentro

30. Martínez del VAdillo, M., La idea de Dios en tiempos de increencia, Atenas, Madrid 1986, 14.

31. ID., o.c., 14-15.

32. Guerra, A., Oración y vida religiosa. Diágnóstico y tarea difícil, Confer 20 (1981) 9.

33. Guerra, A., Oración. En conceptos fundamentales de Pastoral, Ed. Cristiandad, Madrid 1983, 667-668. 
con el Dios y Padre de nuestro Señor Jesucristo y experiencia amorosa de su paternidad tiene que llevar por su mismo dinamismo interno al amor de todos los hombres, hijos de Dios y hermanos en Cristo.

\section{LA ORACIÓN CRISTIANA}

Acabo de escribir una proposición: la oración cristiana. Consta de un sustantivo y de un adjetivo. El sustantivo fija la materia. El adjetivo la determina. Por ello, es necesario aclarar los términos. Saber qué es oración y qué conlleva la oración cristiana.

¿Qué es oración? Como respuesta a este interrogante, voy a proponer algunas definiciones. Comienzo por Agustín. Para Agustín la oración «es la aplicación afectuosa de la mente hacia Dios» ${ }^{34}$. «Tu oración es locución con Dios. Cuando lees, Dios te habla; cuando oras, hablas a Dios» ${ }^{35}$. La fórmula siguiente, típicamente agustiniana, declara muy bien cómo ve Agustín la oración: «invocas a Dios, cuando llamas a Dios a ti. Esto es invocar a Dios, llamarle a ti, invitarle de alguna manera a la casa de tu corazón» ${ }^{36}$.

Teresa de Jesús, maestra incomparable en todo lo que mira a la oración, ha dejado una preciosa definición de la oración: «no es otra cosa oración mental, a mi parecer, sino tratar de amistad, estando muchas veces tratando a solas con quien sabemos que nos ama» ${ }^{37}$.

Preciosa, aunque menos conocida, es la definición de Fr. Luis de Granada: «una petición que hacemos a Dios de las cosas que convienen para nuestra salud. Mas tómase también oración en otro sentido más largo, por cualquier levantamiento del corazón a Dios; $y$, según esto, la meditación y contemplación y cualquier otro buen pensamiento se llama también oración» ${ }^{38}$.

En nuestro tiempo, Ignacio Larrañaga da la siguiente definición: «un trato afectuoso con el Dios que sabemos que nos ama; un avanzar, en la intersubjetividad íntima y profunda, en y con el Señor que se nos ofrece como compañero de vida»" ${ }^{39}$.

Lógicamente todos los autores citados aquí son cristianos y dan una definición de la oración que entraña categorías únicamente cristianas. La oración, como tal, es un fenómeno universal. «Todos los pueblos han orado y oran.

34. San Agustín, Serm. 9 de Passione, n. 3.

35. ID., En. In Ps. 85, n. 7.

36. ID., En. II in Ps. 30, serm. 3, n. 4.

37. SANTA Teresa de Jesús, Vida, 8,5 .

38. Cit. por Maroto, P., Dinámica de la oración, Ed. Espiritualidad, Madrid 1973, 91.

39. Larrañaga, I., Muéstrame tu rostro, Ed. Paulinas, Madrid 1979, 19. 
Han orado y oran como son. Algún fenomenólogo de la religión sugiere que, siguiendo las oraciones de un pueblo, podemos conocer ese pueblo» ${ }^{40}$. Desde esa perspectiva universal la oración aparece como uno de los medios cualificados de la comunicación con la divinidad para pedirle aquellas cosas que el hombre necesitaba. Oración es, por encima de todo, petición.

Tras el concepto de oración, toca ahora desentrañar el adjetivo cristiana. ¿Habrá algo que caracterice a la oración cristiana de forma que la distinga fundamentalmente de cualquier otra clase de oración? Parece que sí. «Cuando se argumenta en pro de la oración ésta se suele concebir como un ejercicio, todo lo necesario que se quiera, pero al fin de cuentas un ejercicio más en la vida del creyente. Al plantear así el problema se comete un error de base. Este error consiste en plantear el problema de la oración desde el terreno de la religiosidad, es decir, como un ejercicio de la piedad personal que busca en Dios solución y respuesta. Ahora bien, lo específicamente cristiano no se basa en la religiosidad, sino en la fe.

Hay, por consiguiente, en la oración cristiana una originalidad que la especifica y la distingue radicalmente de cualquier otra experiencia religiosa. Al afirmar esto, no se trata de defender un cristianismo sin religión ${ }^{41}$; ni siquiera se pretende decir que en la oración no se dé una expresión de nuestra piedad hacia Dios. Pero se debe tener siempre presente que en la oración de un cristiano tiene que haber siempre un elemento decisivo que la especifica y la distingue de la oración que puede hacer cualquier otro hombre religioso; este elemento es la fe. La oración, por consiguiente, en tanto es oración cristiana en cuanto es expresión de la propia fe del creyente» ${ }^{42}$.

Según lo dicho que, por otra parte, responde a lo que la revelación nos dice sobre el particular, la fe da un contenido especial a la oración cristiana. La oración cristiana tiene que ser por necesidad expresión de la fe del que la hace. La relación entre oración cristiana y fe es tan intensa que bien se puede decir que una y otra se llaman, se reclaman. No hay fe verdadera sin oración y no hay oración auténtica sin fe. «La oración es la expresión de la intensidad de la fe de una persona» ${ }^{43}$.

Estas sencillas observaciones obligan a desarrollar detenidamente un tema que se encuentra en la base de una verdadera recuperación de la oración. En un tema de resonancias profundas en la vida espiritual de las personas es

40. Martín Velasco, J., La religión en nuestro mundo, Cit. por GuerRa, A., Oración. En conceptos fundamentales de Pastoral, Ed. Cristiandad, Madrid 1983, 664.

41. Castillo, J.M., Oración y existencia cristiana, Sígueme, Salamanca 1979, 60.

42. ID., o.c., 60-61.

43. ID., o.c., 61 . 
preciso huir de los sentimentalismos y optar por el camino de la teología. Por ello, se impone desentrañar qué significa «la oración como expresión de fe».

\section{a) La oración como expresión de fe}

La proposición transcrita impone una no pequeña tarea. Es necesario detenerse en ella, intentando desentrañar qué se esconde tras de la palabra $f e$. Con más de lo deseado la fe ha aparecido desde una óptica intelectualizada. Según esto, fe era una virtud que nos impulsaba a recibir unas verdades que superaban la simple capacidad humana y se aceptaban por la autoridad extrínseca de Dios revelante. Más o menos así se presentó en el concilio Vaticano I. Sin negar que ello tiene su parte de verdad, hay que reconocer que, a través de esa óptica, la fe perdía su más peculiar forma de ser. La fe bíblica tiene fisonomía personal. La fe cristiana es la respuesta del hombre al Evangelio. «La fe viene de la audición y la audición por la palabra de Cristo». (Rom 10,17). «Id por todo el mundo y predicad el Evangelio a toda criatura. El que creyere y fuere bautizado se salvará; mas el que no creyere, se condenará» (Mc 16,1516). «Id, pues, y haced discípulos a todas las gentes bautizándolas en el nombre del Padre y del Hijo y del Espíritu Santo, y enseñándoles a guardar todo lo que yo os mando» (Mt 28, 19-20a). Si se profundiza en el mensaje de estos textos, que hablan de la fe como respuesta a una buena noticia, el Evangelio, se advierte inmediatamente una estructura personal. El Evangelio, en efecto, tiene un rostro personal: Cristo. Nadie se convierte propiamente a una doctrina. La conversión es siempre a una persona. La fe en cristiano es el encuentro personal con Cristo, que nos trae la buena noticia de que en él, en su obra y en su palabra, Dios ofrece al hombre la salvación. Por Jesús y en Jesús Dios sale de una forma definitiva al encuentro del hombre y por la fe el hombre se encuentra en Jesús y por Jesús con Dios. «Convertirse a la fe es convertirse a una persona, encontrar la fe es encontrar a esta persona, aceptar la fe es aceptar a esa misma persona. Así ocurrió en las experiencias paralelas de san Pablo y san Juan. Y así tiene que ocurrir en todo encuentro verdadero con la fe. La moderna teología ha insistido acertadamente en que la fe tiene una estructura personal» ${ }^{44}$. «La fe implica una relación interpersonal con Jesús, de tal manera que en tanto hay fe en cuanto se dé esta adhesión a la persona del Señor y esta aceptación de Cristo como norma decisiva de la propia existencia. En segundo lugar, esta aceptación y esta adhesión provoca una determinada experiencia, que se puede describir como la experiencia de los pobres y de los niños en el sentido evangélico, la experiencia de aquellos que se saben justificados por la fe, no por su propia conducta» ${ }^{45}$.

44. ID., o.c., 66.

45. ID., o.c., 79. 
Vista la fe ante todo y sobre todo como encuentro personal con Cristo, los pasos a dar no resultan excesivamente complicados. Según ello, la oración en cristiano sólo puede tener su origen en la fe como encuentro personal. «La oración cristiana tiene que brotar de aquello que especifica al cristiano, es decir, de la fe» ${ }^{46}$. De la fe que es, por antonomasia, un encuentro personal. Por tanto la oración cristiana se configura conforme a una categoría de encuentro con alguien, no con algo, y se nutre de una estructura interpersonal. Para tomar el pulso a todo lo que esto significa y conlleva, es preciso detenerse un poco en el estudio fenomenológico del encuentro. Por cierto que es un tema estudiado con profusión y altura. El encuentro, fenomenológicamente considerado, conlleva la relación profunda entre un 'yo' y un 'tú'. El encuentro es de tal categoría que no puede darse más que entre personas. Es con mucho la experiencia humana más profunda y característica. «El hecho fundamental de la existencia humana es el hombre con el hombre» ${ }^{47}$.

Por su dignidad y valor intrínseco el encuentro supone y exige algunas condiciones. La primera de esas condiciones y tal vez la más representativa es el amor. No hay encuentro sin amor, por más que las personas estén localmente cercanísimas. Es imposible confiarse a alguien, y esto es encontrarse, si no existe amor. El amor es, por tanto, una de las condiciones previas para la oración como encuentro. Cuando falta, la oración resulta inexplicable. Sin sentido. Pérdida de tiempo. Cuando se halla presente, el tiempo de oración resulta el más agradable de la vida. Sucede como en el caso de los enamorados. Sus momentos más felices y gratificantes son aquellos en los que se encuentran juntos. De ahí que la oración, como experiencia de fe, sea la forma más bella y gratificante de expresar nuestro amor a Cristo. De amarle y de sentirnos amados por él. Amor y oración, oración y amor no sólo se reclaman, sino que se potencian mutuamente. Lo cual quiere decir que no hay mejor forma de avivar el amor, de crecer en el amor, que la oración auténtica. Y, si el amor es la esencia de la santidad, entendemos con facilidad que los grandes místicos, los hombres del intenso encuentro con Cristo, piénsese en Teresa de Jesús, equiparen santidad con oración. Cuanto más perfecta sea la oración, tanto más el hombre de fe ha avanzado en los caminos de la santidad.

$\mathrm{El}$ encuentro entre personas que se aman se traduce en gestos y sobre todo, en palabras, que es la forma más específicamente humana de relacionarse. Por ello, la oración entendida como encuentro interpersonal, culmina en el diálogo. Un diálogo, por cierto, con sus características, pero, al fin y al cabo, diálogo. Hablar y escuchar. Escuchar y hablar. Y ello en un clima de acogida

46. ID., o.c., 80. Cf. también Fe cristiana y vida religiosa: Proyección 60 (1968) 181-182.

47. Buber, M., ¿Qué es el hombre? México 1964, 146-147. 
y aceptación. Rompiendo distancias. «Desde el momento en que a Cristo se le encuentra como persona - no como simple idea o como mero proyecto-, desde ese momento no hay más remedio que dialogar con él, en la presencia y en la efusión de quien sabe y experimenta que su campo afectivo existe, está lleno y bien delimitado. La vida entonces adquiere su plena significación y nada en el hombre queda al descubierto, a merced de tantos desalientos y tantas traiciones como la vida nos presenta desgraciadamente cada día» ${ }^{48}$.

Quiero insistir en el tema de la oración como diálogo. Y lo quiero hacer para evitar juicios equivocados y situaciones comprometidas. Seguramente que muchas de las personas, que se dedican con asiduidad y cariño a la oración, se sienten decepcionadas, cuando se les dice que la oración es un diálogo con Dios. Dios no les ha hablado nunca directamente. Y es así, sin quitar la posibilidad de que alguna vez acontezca lo contrario. Por tanto, cuando se habla de la oración como diálogo con Dios, es necesario tener presente que este diálogo tiene unas características peculiares. Una concepción simplista del diálogo o una equiparación de la oración-diálogo con el diálogo humano no conducen más que a un callejón sin salida. El diálogo con Dios en la oración es de naturaleza muy peculiar. Nunca podemos dialogar con Dios a cara descubierta. Dios aparecerá siempre de espaldas y nunca podremos ver su rostro, para usar una imagen bíblica (Cf. Ex 33,23). El diálogo con Dios sólo es posible a través de múltiples mediaciones. Entre estas mediaciones ocupa lugar de preferencia la Biblia. Por algo se la llama palabra de Dios. La Biblia tiene que ser la fuente primera que riegue y fertilice el diálogo-oracional con Dios. $\mathrm{Al}$ hablar aquí de la Biblia no me refiero tan sólo al canon de los libros inspirados, interpretados y vistos desde una óptica histórico-crítica. La Biblia no es simplemente una palabra escrita que se mantienẹ incólume y sin referencia a la vida. La Biblia es un libro que se alimenta y se enriquece de y en la vida de una comunidad, la vida de la Iglesia. La Iglesia que ha recibido el don del Espíritu Santo, que debe conducirla al pleno señorío de la verdad (cf. Jn 14,26). «Esta tradición, que deriva de los apóstoles, progresa en la Iglesia con la asistencia del Espíritu Santo, puesto que va creciendo en la comprensión de las cosas y de las palabras transmitidas, ya por la contemplación y el estudio de los creyentes, ya por la meditación en su corazón (cf. Lc 2,19 y 51); ya por la percepción íntima que experimentan de las cosas espirituales; ya por el anuncio de aquellos que con la sucesión del episcopado recibieron el carisma cierto de la verdad. Es decir, la Iglesia en el decurso de los siglos, tiende constantemente a la plenitud de la verdad, hasta que en ella se cumplan las palabras de Dios» ${ }^{49}$.

48. Castillo, J.M., La alternativa cristiana, Sígueme, Salamanca 1978, 221.

49. Vaticano II, DV. $8 \mathrm{~b}$. 
Como se ve por esta luminosa enseñanza del concilio Vaticano II, la Biblia no se reduce sin más ni más al contenido inmediato que puede aparecer tras un meticuloso análisis histórico-crítico. La Biblia puede apuntar, y de hecho así sucede, a mensajes que sólo a través de la óptica eclesial quedan patentes. Algo de esto queda reflejado en la fórmula tradicional: «la ley de orar se constituye en ley de creer». Lo cual supone la superación del crudo biblicismo, que termina casi siempre en gran decepción.

Desde la óptica de la historia el concilio Vaticano II ha puesto de relieve la importancia de los signos de los tiempos, para poder, de alguna manera, escuchar la voz del Espíritu Santo. «Es propio de todo el pueblo de Dios, pero principalmente de los pastores y de los teólogos, auscultar, discernir e interpretar con la ayuda del Espíritu Santo, las múltiples voces de nuestro tiempo y valorarlas a la luz de la palabra divina, a fin de que la verdad revelada pueda ser mejor percibida, mejor entendida y expresada en forma más adecuada» ${ }^{50}$. Esta consigna es de trascendental importancia para todo orante. Sólo así se puede conseguir la indispensable conexión que debe haber entre oración y vida. Oración y vida tienen que ir siempre de la mano. Hay que evitar que se dé entre ellas tanta separación como contraposición. Es ello un error clarísimo y de consecuencias imprevisibles. "Ante la conciencia de muchas personas la oración aparece como un ejercicio yuxtapuesto, a veces contrapuesto, a la vida. Vida y oración son, entonces, dos realidades al margen la una de la otra. Y esto no sólo por lo que se refiere a la vida corriente de cada día, sino lo que es peor, por lo que respecta a la misma actitividad apostólica estrictamente tal. (A esto apunta, sin pretenderlo, la tipología Marta-María, Raquel-Lía). Tal tipología no tiene su fundamento en la Biblia, sino que es de origen muy posterior. Aparece por primera vez en la Gran carta del Pseudo-Macario ${ }^{51}$. Sin embargo, la enseñanza de la Biblia sobre la oración descubre un horizonte distinto: la oración brota de la misma vida, de la historia, de la existencia del pueblo. Los salmos y los himnos, que se hallan en el Antiguo Testamento, traducen en oración la historia de Israel, el drama de la salvación. El diálogo del hombre con Dios brota de los hechos concretos de la vida, los interpreta, los convierte en oración de alabanza, de acción de gracias, de petición. De este modo, se llega a un conocimiento más profundo del quehacer humano, $\mathrm{y}$, sobre todo, se penetra en el misterio de Dios presente en la historia» ${ }^{52}$.

Se ha hecho referencia al Antiguo Testamento para recalcar que el pueblo de Israel alimenta su oración de los acontecimientos que tejen su vida. Otro tanto se puede decir de lo que sobre el particular nos narra el Nuevo Testa-

50. VATICANO II, GS. 44b.

51. Cf. BOUYER, L., Histoire de la spiritualité chrétienne, I. París 1960, 446-447.

52. CASTILlo, J.M., Oración y existencia cristiana, Sígueme, Salamanca 1979, 40. 
mento. En efecto, todo lo que el Nuevo Testamento nos dice sobre la oración reafirma que ella nace de y en la fuente de la vida. Son los acontecimientos los que nutren la oración de Jesús y de quienes se nos presentan como sus seguidores más cualificados. «En el conjunto del Antiguo Testamento hemos observado que la oración está presente en el hombre que se mantiene particularmente atento a la vida; más aún, su oración nace de la vida.

También en el hombre del Nuevo Testamento se sigue dando esta característica, pero habrá que profundizar en la plenitud a la que ahora llega la oración. Dicha plenitud no es tanto un mérito del hombre, una facultad suya - como si hoy supiera orar mejor que David, que Elías o que Jeremías-. Respecto a la oración que nace de la vida, nos encontramos en el mismo plano que los que nos precedieron en la fe; también nosotros clamamos hacia el Señor, porque hay algo que nos oprime, que nos aplasta, que nos deja vacíos, que nos aliena, que nos reduce; y pedimos que el Señor nos libere.

La novedad es otra, y no está en nosotros, sino en Cristo» ${ }^{53}$.

La atención intensa a los signos de los tiempos debe constituir la mejor fórmula terapéutica contra la grave enfermedad de disociar oración y vida. $\mathrm{Si}$ la espiritualidad tradicional ha sido tachada frecuentemente de evasionista y descomprometida, en ello ha tenido influencia de primera categoría un estilo de oración, que ha privilegiado el desierto como lugar de encuentro con Dios. $\mathrm{Y}$ esto, que tiene su parte de verdad, no es ni mucho menos toda la verdad. Efectivamente, los grandes hombres bíblicos tuvieron su experiencia de Dios en el desierto. El mismo pueblo de Dios corrió la misma suerte, hasta tal punto que el profeta Oseas privilegia esa experiencia, cuando dice, hablando en nombre de Dios: «Por eso yo la voy a seducir: la llevaré al desierto y hablaré a su corazón» $(2,16)$. Sin embargo, todo ello acontece mirando siempre a la historia, no como evasión del compromiso histórico. La tarea a realizar no está en el desierto, sino en la vida. «Dios quiso hacer pasar a su pueblo por 'esta tierra espantosa' (Dt 1,19), para hacerle entrar en la tierra en la que fluyen leche y miel. Este acontecimiento va a transformar el simbolismo precedente. $\mathrm{Si}$ el desierto sigue conservando el carácter de lugar desolado, sobre todo evoca una época de la historia sagrada: el nacimiento del pueblo de Dios. El simbolismo bíblico del desierto no puede, pues, confundirse con tal o cual mística de la soledad o de la fuga de la civilización; no enfoca una vuelta al desierto ideal, sino un paso por el tiempo del desierto, análogo al de Israel» ${ }^{54}$. Seguramente que en este contacto con la vida se encuentra la fuente purificadora de los trastornos y malas adherencias que amenazan siempre a la oración. Sólo al contacto con la vida la oración puede eliminar el peligro de convertirse en una

53. Florio, G., La palabra de Dios escuela de oración, Sal Terrae, Santander 1986, 69.

54. Dufour, L., Desierto. Vocabulario de teología bíblica, Herder, Barcelona 1972, 226. 
bonita ideología. «Hemos de poner atención en que nuestra oración no se convierta en una alegre evasiva, en una plasmación de la apatía del alma, de la indiferencia, de la insensibilidad ante el dolor ajeno... La oración plena es aquella que va acompañada de la disposición de abrazar la propia responsabilidad. Y esa oración se nutre de aquellas experiencias adversas y dolorosas que no le faltan a quien ha abrazado y puesto en ejercicio el riesgo de su responsabilidad» ${ }^{55}$.

Con lo dicho se ha desmitificado el desierto como lugar exclusivo del encuentro con Dios. Cosa que no ha sucedido en muchos maestros de la espiritualidad cristiana, al privilegiar el desierto como lugar casi exclusivo del encuentro con Dios. Ello no significa la anulación de la mística del desierto. El desierto puede y debe ayudar a potenciar el encuentro con Dios, pero sin adquirir carta de exclusividad. «El desierto, concebido como espacio y como ambiente, no puede ser norma para todos y para siempre. Esto no excluye el que pueda haber vocaciones especiales en la Iglesia para una vida solitaria; como no excluye tampoco la utilidad de determinados tiempos de retiro. Pero ni esas vocaciones extraordinarias ni esos tiempos de excepción pueden ser la norma y el planteamiento para nuestra vida de oración, la oración de todos los días. Quizás en esto estuvo el inadecuado planteamiento de este problema en tantos libros que al tratar de estas cosas, las formulan de manera que uno percibe una especie de malestar y presiente en el fondo que no se resuelven allí los verdaderos problemas que la vida plantea. La oración exige soledad..., pero no aislamiento. Nuestro desierto es el Señor. Vivir la soledad de la fe, en la presencia al mundo y a los demás, he aquí, la verdadera cuestión. En la práctica será necesario alternar experiencias de retiro, de desierto geográfico y ambiental, con la experiencia diaria del trabajo y la convivencia» ${ }^{56}$.

El encuentro no se puede dar sin amor. Éste exige presencia y diálogo. Presencia y diálogo que, al tratarse de la oración, reviste caracteres peculiares. De ello se ha hablado en los párrafos anteriores. Amor, presencia y diálogo culminan en abandono. Sé de alguna persona que todos los días se dirige al Corazón de Jesús y le dice: cuida tú de mí, que yo cuidaré de ti. No puede ser de otra manera. El abandono quita toda sensación de desconfianza y sabe cómo comportarse en los momentos de prueba. Abandonarse a otro, en el caso de la oración, a Otro es dejar en sus manos todos los cuidados, todas las preocupaciones, todas las angustias. Es, en pocas palabras, sentirse seguro en las manos de Dios. Todas las personas, que viven con intensidad la oración, se saben beneficiarias de estas palabras de la primera epístola de Pedro: «confiadle todas vuestras preocupaciones, pues él cuida de vosotros» $(5,7)$. Y también

55. Metz, J.B., Invitación a la oración, Sal Terrae, Santander 1979, 26-27.

56. Castillo, J.M., Oración y existencia cristiana, Sígueme, Salamanca 1979, 59. 
son capaces de captar el mensaje de estas maravillosas palabras del Señor: «No andéis preocupados por vuestra vida, qué comeréis, ni por vuestro cuerpo, con qué os vestiréis. ¿No vale más la vida que el alimento, y el cuerpo más que el vestido? Mirad las aves del cielo que no siembran ni cosechan, ni recogen en graneros; y vuestro Padre celestial las alimenta. ¿No valéis vosotros mucho más que ellas?... Así que no os preocupéis del mañana: el mañana se preocupará de sí mismo. Cada día tiene bastante con su inquietud» (Mt 6, 2526.34).

Todas estas características del encuentro tienen como aglutinante el amor. Cuando hay amor se comprende que haya presencia, diálogo, confianza, abandono. Todo ello es mucho y es gratificante, sobre todo desde el punto de vista de la experiencia de Dios, tal y como se desprende de la fe concebida como encuentro interpersonal. Sin embargo, aún queda algo muy importante a tener en cuenta en el encuentro. De ello ha tomado buena nota la fenomenología del encuentro. Se trata de lo que los fenomenólogos llaman co-ejecución (mitvollzug). De él dice Laín Entralgo: «el otro no es ahora para mí obstáculo, ni instrumento, ni espectáculo, ni objeto transformable, sino persona; mi relación con él no consiste en contemplación o en manejo, sino en coejecución» ${ }^{57}$.

La palabra co-ejecución es suficientemente expresiva. Co-ejecución no se queda en el plano meramente afectivo, sino que se proyecta principalmente sobre el plano efectivo. Cuando dos personas se encuentran y viven la relación yo-tú, la similitud y la identidad en el obrar se hacen una constante. Desde esta óptica aparece con claridad qué es lo que Jesús quiere decir, cuando afirma: «Si alguno quiere venir en pos de mí, niéguese a sí mismo, tome su cruz cada día y sígame» (Lc 9,23). Dicho de otra forma: haga lo que yo he hecho. De este modo el término co-ejecución tiene un valor complexivo. Encierra, por así decirlo, a toda la persona con lo que es, con lo que ama y con lo que hace. «Ahora se puede comprender mejor la singular importancia que en la convivencia humana adquieren el silencio, la intimidad y el abandono en el otro. Porque la verdadera relación y el verdadero encuentro no se pueden entablar ni a partir ni a base del solo conocimiento, ni mucho menos del uso o del mando. Solamente en la co-ejecución completa, que no es solamente coactividad, sino además co-efusión o co-afección y comprensión honda, que nos viene dada no el 'ser para' el otro, sino en el 'estar con' el otro, en el contagio de la presencia y la existencia compartida. Porque se trata de poner en movimiento mecanismos profundos del ser personal, que desde luego son preconceptuales y que no tienen más posibilidad de actuarse, si no es en función de la presencia del 'tú' en cuanto persona. No por mucho conocer a alguien se le quiere y se le

57. Entralgo, L., Teoría y realidad del otro, II, 237. 
acepta; solamente en la co-ejecución y la co-efusión que se engendran en la convivencia es posible la 'instancia', el estar en el otro, para sentir lo que él, co-ejecutar con él» ${ }^{58}$.

Para profundizar en lo que se acaba de decir, es preciso tener en cuenta «el sentido fundamentalmente pasivo de la experiencia afectiva, de toda experiencia afectiva. Amar no es lo mismo que querer, lo cual es tanto como decir que afecto no es lo mismo que determinación, decisión. La autodeterminación de la voluntad y la co-efusión afectiva no son términos convertibles. Y no son términos convertibles, porque en el amor -en el encuentro interpersonal, por lo tanto- se dan unas notas diferenciantes, que no existen en el simple acto de querer, en la sola decisión que puede brotar en mí como producto de algo que he visto, que he comprendido. Ahora bien, precisamente la nota típicamente especificante del verdadero amor es la pasividad» ${ }^{59}$.

La palabra y el concepto encuentro, tal y como ha quedado dibujado, da a la oración cristiana un valor y una importancia verdaderamente excepcionales. La oración se constituye en la forma más cualificada de la relación con el Absoluto. Con el Absoluto de rostro personal. En la oración nos encontramos entre celajes de misterio con el Dios personal. La oración es la forma mejor de vivir la relación profunda entre Dios y el hombre. Lo cual significa, debe significar al menos, que la oración es el medio por antonomasia de conocer a Dios y de ser conocido por Dios, dando al término conocer su profundo significado bíblico, que es tener experiencia de algo. Por tanto, la oración es el medio mejor para adquirir la experiencia de Dios. Y no hay que olvidar que esa experiencia es lo único que justifica la acción apostólica. De ahí que la oración es también de suyo el mejor apostolado.

Tener experiencia de Dios es gustarlo sobre todo como amor. «Dios es caridad» $(1 \mathrm{Jn} 4,16)$. Amor en sí y amor proyectado fuera de sí. «En esto consiste el amor: no en que nosotros hayamos amado a Dios, sino en que Él nos amó y nos envió a su Hijo como propiciación por nuestros pecados... Nosotros amemos, porque Él nos amó primero» (1 Jn 4,10.19). El amor de Dios se ha hecho historia viva, realidad palpable en la persona de su Hijo hecho hombre. "Tanto amó Dios al mundo que dio a su hijo único, para que todo el que crea en él no perezca, sino que tenga vida eterna» (Jn 3,16). En la luz del Verbo, hecho hombre, se ilumina el misterio del hombre. «En realidad, el misterio del hombre sólo se esclarece en el misterio del Verbo encarnado» ${ }^{60}$. La oración es, desde esta óptica, el mejor medio para alcanzar la verdadera visión del hombre. Sin exaltaciones tontas y sin pesimismos desesperantes ${ }^{61}$.

58. CASTillo, J.M., Oración y existencia cristiana, Sígueme, Salamanca 1979, 86.

59. ID., o.c., 86-87.

60. VATICANO II, GS. 22a.

61. Vaticano II, cf. GS. 12b. 
La oración, entendida como encuentro, nunca puede ser alienante. Y no puede serlo, porque el verdadero contacto con Dios, a través de la oración, tiene que traducirse en identificación con los sentimientos del mismo Dios. Y, por tanto, en vivencia de la aventura humana. Dios no se ha quedado encerrado en sí mismo, sino que ha salido al paso del hombre en su andadura histórica, asumiendo en plenitud el papel de protagonista de la misma. El Dios cristiano no es un Dios dormilón y lejano. Es un Dios activo y presente. Se interesa por el hombre y quiere para el hombre caminos de libertad. Reprueba todo lo que pueda significar esclavitud para el hombre. El hombre de oración debe en fuerza de la misma comprometerse con el hombre, con todo lo verdaderamente humano. Nadie como él podrá ser profeta de la justicia y denunciar sin tapujos todo aquello que, de alguna manera, se interponga en el derecho de todos los hombres a ser verdaderamente personas libres. «La mística de la oración es concreta; incluye atención a la responsabilidad, que es social y política...

Los que oran 'en el espíritu de Jesús' no pueden orar volviendo las espaldas a los que sufren...

Quienes oran 'en el espíritu de Jesús' podrán ser despreciados por los prudentes y por los inteligentes (por los que se consideran tales); pero no serán despreciados por los desgraciados, por los que padecen, por los oprimidos -ni tampoco por los culpables- ni por Dios! Nuestra oración cristiana es, en su misma esencia, concreta y política» ${ }^{62}$.

La oración cristiana se alimenta de y alimenta $a$ dos movimientos convergentes e inseparables: el amor a Dios y el amor a los hombres. Dos extremos que tienen su punto de intersección en el hombre Cristo Jesús. «Porque hay un solo Dios, y también un solo mediador entre Dios y los hombres, Cristo Jesús, hombre también que se entregó a sí mismo como rescate por todos» (1 Tim 2, 5-6a).

De ahí que la oración cristiana es, como culminación de su significado, encuentro con Jesús. «Si creer es relacionarse personalmente con Cristo Jesús y toda relación personal es co-ejecución y co-efusión, es patente que la intensidad de la fe tiene que expresarse en la intensidad de una co-ejecución, una coefusión y una presencia. A esto nos referimos, al hablar de la oración como experiencia de fe» ${ }^{63}$. La oración, es, por tanto, debe serlo al menos, la culminación, la forma más sublime de vivir la fe como encuentro con Cristo Jesús. $\mathrm{Y}$, desde esta perspectiva, la oración se convierte en el medio más firme y directo para asimilar y asumir los sentimientos de Cristo Jesús. En forma similar a Jesús, el hombre de oración sabrá unir en su vida amor a Dios y amor al

62. METZ, J.B., Invitación a la oración, Sal Terrae, Santander 1979, 25-26.

63. Castillo, J.M., Oración y existencia cristiana, Sígueme, Salamanca 1979, 89. 
hombre, entrega a Dios y entrega al hombre, dedicación a Dios y dedicación al hombre. Nunca cometerá el error de separar trascendencia e inmanencia, verticalidad y horizontalidad. No potenciará nunca una en perjuicio de la otra. Sabrá, como dice el mismo Jesús, dar a Dios lo que es Dios y al César lo que es del César (Cf. Mt 22,21). He ahí por qué la oración cristiana auténtica no es alienante. Nunca apartará al hombre de los compromisos con el hermano. «También en nuestra vida y en nuestra praxis de seguimiento de Jesús ha de hacerse visible y palpable — para los demás y para nosotros mismos- a quién oramos y en quién pensamos cuando nombramos a 'Dios'. En nuestra actitud deben poder adivinarse los rasgos de ese Dios liberador y sublime al que se dirigen nuestras oraciones. Digamos de una vez por todas que no existe refutación 'puramente teórica' y efectiva de la sospecha de que nuestras oraciones son el opio del pueblo o de que son nada más para gentes acríticas, de que son la clásica expresión de una falsa conciencia; por decirlo así, un suspiro de la criatura equivocadamente dirigido. Tampoco se puede ofrecer una resistencia eficaz 'puramente teórica' al intento que hoy existe de despojar a la oración de su autenticidad definiéndola como una 'función sistemática' de nuestra sociedad liberal, como un remedio oportuno para absorber las frustraciones y desilusiones socialmente producidas, como instrumento de higiene social en pro del funcionamiento sin dificultades de nuestra vida social. La única resistencia que ante los demás y ante nosotros mismos podemos ofrecer es aquella que se expresa en el seguimiento vital de aquel que llama 'Padre' suyo y nuestro al Dios de su oración» ${ }^{64}$.

La oración cristiana, vivida desde la fe como encuentro interpersonal, es humanamente gratificante. ¿Qué se quiere decir con esto? El hombre necesita, para mantener su equilibrio humano, sentirse amado. El hombre se realiza y mantiene su equilibrio no sólo cuando ama, sino cuando, al mismo tiempo, es amado. Quien no se siente amado terminará normalmente por perder su equilibrio. Será una persona desquiciada. Este peligro amenaza a todo hombre y la amenaza viene desde múltiples frentes. Es necesario que el hombre ponga en movimiento una serie de resortes, a fin de vencer los múltiples ataques. Y, entre éstos y seguramente el más significativo, al menos para el creyente en Cristo Jesús, se encuentra la práctica de la oración cristiana, concebida precisamente como experiencia de fe. En la oración como encuentro el hombre descubre no un dios cualquiera, sino al Dios-amor. Dios-amor que está en el origen, en el desarrollo y estará en el final de su vida. Y que está así no como mero espectador, sino como compañero de viaje, que se interesa por él, que todo lo dispone para su bien y que lo ama apasionadamente. El encuentro personal

64. METZ, J.B., o.c., 29-30. 
con Dios, con el Dios y Padre de Nuestro Señor Jesucristo, hecho realidad en la oración, hará descubrir al creyente el valor de estas palabras: «¿Acaso olvida una mujer a su niño de pecho, sin compadecerse del hijo de sus entrañas? Pues aunque ésas llegasen a olvidar, yo no te olvido» (Is 49,15). El verdadero orante en cristiano siempre se siente amado por Alguien. Tal amor le hace sentirse útil y ver su vida con sentido, aunque las circunstancias humanas o históricas sean absurdas e incluso contradictorias. $Y$, por sentirse amado, el orante cristiano tendrá a su alcance el instrumento más adecuado para verse afectivamente satisfecho. No habrá en él grietas por las que se pueda filtrar la insatisfacción o la angustia. Verá la vida y los acontecimientos, sean del signo que sean, como verdaderos regalos de Dios. Nada ni nadie podrá arrebatar al orante cristiano la paz, la serenidad, el equilibrio. El espacio afectivo, ese hueco interior que todo hombre debe llenar, si quiere responder a sus exigencias afectivas, es saturado por la presencia de un Dios, a quien se siente cercano y amante. Los grandes orantes han sido siempre hombres de paz. La razón fundamental de esa paz se encontraba primariamente en el descubrimiento del amor de Dios por medio de una oración intensa.

La oración cristiana, se ha dicho a lo largo de estas líneas, brota de la fe entendida como encuentro interpersonal. $Y$ esto es lo que la caracteriza y la distingue de cualquier otra forma de oración. «La oración, por consiguiente, en tanto es oración cristiana en cuanto es expresión de la propia fe del creyente» ${ }^{65}$.

¿Qué decir, a la luz de todo esto, de la llamada contemplación religiosa o de las formas orientales de oración apoyadas en los métodos del Yoga o del Zen, que tanto eco parecen tener en nuestro ambiente religioso? ¿Es aconsejable, desde la perspectiva cristiana, la práctica de tales formas de encuentro con el Absoluto? ¿Existen diferencias sustanciales entre la experiencia religiosa y el fenómeno contemplativo, cualquiera que sea la forma de realizarlo? Estos interrogantes no son fútiles. Suele existir al respecto bastante confusionismo. Y no sólo confusionismos. También se dan juicios equivocados, hasta el extremo de creer que orar en cristiano es lo mismo que orar en contemplativo o que ejercitar la praxis del Yoga o del Zen. Por ello, creo muy importante, ahora que estamos tratando de caracterizar la oración cristiana, dar una respuesta correcta a los interrogantes antes planteados. Respondiendo al tema del fenómeno contemplativo, se responde también a los otros temas.

Entre oración cristiana y contemplación religiosa existen diferencias sustanciales. Vaya esto por delante, para evitar confusionismos. La contemplación religiosa hunde sus raíces en la misma estructura religiosa del hombre,

65. Castillo, J.M., Oración y existencia cristiana, Sígueme, Salamanca 1979, 61. 
entendiendo aquí por estructura la capacidad y casi necesidad humana de apertura al misterio, a lo absoluto. La contemplación religiosa es la forma más conspicua de poner en marcha la estructura religiosa del hombre. Es aquí donde el hombre manifiesta preferentemente su condición religiosa. Es un movimiento que nace del hombre y se proyecta hacia el absoluto. El camino se traduce en una ascensión. El hombre se eleva hasta el absoluto. Uso el término absoluto como caracterización de ese fenómeno que es universal y en el que, en muchos casos, no hay tras de él un rostro personal. En el fenómeno cristiano el proceso es inverso. No es el hombre quien inicia su camino hacia Dios. Es Dios quien sale al encuentro del hombre. Dios viene al encuentro del hombre en donde éste se mueve y vive: en la historia. La venida de Dios al encuentro del hombre se realiza de forma total y única en la persona, obra y palabra de Cristo Jesús. En su Hijo, hecho hombre, Dios se hace historia. Por ello, la oración cristiana y la mística de nervio cristiano se enraizan en la vida. Nunca se traducen en huida y aislamiento. El lugar de encuentro entre el Dios cristiano y el hombre de fe es la propia vida. Con ello aparece una diferencia radical entre oración cristiana y contemplación religiosa. «Interesa, por tanto, dejar bien claro que la oración de un cristiano no se puede ni plantear ni enjuiciar con el solo criterio del fenómeno contemplativo» ${ }^{66}$.

Profundizando un poco más, se hacen algunas reflexiones que puntualizan y amplían lo anteriormente dicho. Se acepta y se pone de relieve que la fe, que viene de Dios, se enraiza en la estructura religiosa del hombre. No se trata pues, de dos cosas contrapuestas, como si la una destruyera o anulara a la otra. Se trata de dos cosas complementarias. «De esta manera lo 'cristiano' y lo 'religioso' se mezclan y hasta se unifican en la respuesta que el hombre da a Dios. Por esta razón, se comprende fácilmente que existen determinados puntos de coincidencia entre la experiencia de un creyente y la religiosidad de un budista, por ejemplo» ${ }^{67}$.

Si la experiencia cristiana y la experiencia religiosa son complementarias, no se puede olvidar que existe entre ellas una diferencia abismal. La experiencia cristiana, nacida de la fe o vivida en la fe, como don de Dios, se caracteriza de forma muy concreta por la referencia personal a la persona de Cristo Jesús. Sin esta referencia personal a Cristo Jesús no hay ni puede haber experiencia cristiana. Y, con ello, o por ello, la experiencia cristiana se diferencia de cualquiera otra experiencia religiosa. Sobre el particular se expresa el cardenal $\mathrm{H}$. de Lubac: «Tal es finalmente el trazo en el cual se reconoce la mística cristiana, porque define toda realidad cristiana. En Jesucristo hemos tenido noso-

66. ID., o.c., 152.

67. ID., o.c., 153 . 
tros la revelación perfecta, definitiva, del ser humano como ser personal. La revelación de Dios al hombre fue al mismo tiempo revelación de una relación entre el hombre y Dios. Ahora bien, lo que concierne a un término toca también al otro: al mismo tiempo, pues, que Dios se revela en su ser tripersonal, interviniendo en nuestra humanidad, él nos revela a nosotros mismos como seres personales capaces de responderle, por su gracia, en el amor. Lo que nosotros llamamos, en la Iglesia católica la mística no es sino la actualización consciente de este don de Dios» ${ }^{68}$.

Con un estilo muy incisivo y directo $\mathrm{H}$. Küng se refiere al tema en la forma siguiente: «Lo peculiar, lo originario del cristianismo es considerar a este Jesús como últimamente decisivo, determinante y normativo para las relaciones del hombre con Dios, con los demás hombres y con la sociedad: considerarlo como 'Jesucristo', según la breve fórmula bíblica»" ${ }^{69}$.

Todo esto no es más que explicitación del dato relevado. Por Jesús y en Jesús Dios sale al encuentro del hombre. Por él y en él el hombre se encuentra con Dios. El hombre Cristo Jesús es plenamente el mediador, el lugar del encuentro más plenamente personal entre Dios y el hombre. «El fondo del contraste entre la experiencia cristiana y la espiritualidad oriental reside precisamente aquí: en la 'interioridad recíproca' como superación de la 'interioridad' solitaria» ${ }^{70}$.

Globalmente ha quedado ya respondida la problemática que se puede suscitar sobre el Yoga y el Zen. Entre experiencia cristiana y prácticas orientales de ascensión mística hay diferencia abismal. Tanto es así que, de no tener cuidado exquisito en el ejercicio del Yoga o del Zen, se puede corromper la experiencia religiosa cristiana. Es necesario recalcar que tales métodos de ascensión mística no se pueden confundir con la experiencia cristiana. No ora ni más ni mejor cristianamente hablando aquél que es un maestro consumado en tales métodos. Pueden, eso sí, ayudar a crear un clima propicio a la hora de realizar una verdadera oración cristiana. En esto radica su posible valor. El valor de la oración cristiana no radica ni en la capacidad de contemplación ni en la intensidad de los sentimientos que uno puede tener. El valor de la oración cristiana se manifiesta en la vida de fe, esperanza y caridad. Sobre todo, en esta última. La oración que no se traduce en entrega a los demás no será nunca oración cristiana. «La oración es verdaderamente cristiana nada más que cuando el cristiano sale de ella con una fe, una esperanza y una caridad más intensas, es decir, decidido a vivir más sinceramente como hijo de Dios,

68. De Lubac, H., en Castillo, J.M., Oración y existencia cristiana, Sígueme, Salamanca $1979,154$.

69. Kueng, H., Ser cristiano, Ed. Cristiandad, Madrid 1977, 151.

70. Castillo, J.M., Oración y existencia cristiana, Sígueme, Salamanca 1979, 154. 
con Cristo Jesús. Esta decisión distingue a la oración cristiana de toda otra oración pagana, musulmana, budista... La capacidad orante en cuanto tal no es, por lo tanto, lo que puede distinguir a un cristiano; ni por ella se puede medir el valor de la oración de un creyente. Es una equivocación, desgraciadamente muy extendida, el enjuiciar el grado de vivencia cristiana de una persona por su capacidad meramente contemplativa o incluso cierta atracción mística» ${ }^{71}$.

\section{b) La oración como experiencia del Abba}

Sin apenas notarlo, aunque ello ha estado ya muy presente en muchas de las cosas anteriormente dichas, nos encontramos con un tema tiernamente sugestivo y de una gran importancia para el tema de la oración cristiana. Se trata de la oración sostenida y alimentada por la dulce experiencia del $A b b a$, tal y como la vivió Jesús nuestro hermano mayor, el primogénito entre muchos hermanos.

La visión de Dios como padre, que «abarca desde los tiempos más lejanos algo de lo que la palabra madre significa entre nosotros» ${ }^{72}$, es una visión que, con matices diversos y ricos, se encuentra muy viva y presente a lo largo y a lo ancho de la Sagrada Escritura. Recoger y resaltar algunos hitos de este mensaje bíblico no carece de interés. Al contrario, ello nos ayudará sustancialmente a poder saborear lo que Jesús gustó al invocar a Dios con el título infantil de Abba.

El A.T. es pródigo en expresiones en las que Dios recibe el nombre de $\mathrm{Pa}$ dre. Ellas manifiestan la experiencia profunda que el pueblo de Israel llegó a tener del amor y la ternura de su Dios. En el cántico de Moisés encontramos esta interpelación al pueblo de Israel que, después de haber sido tratado con tanto cariño por parte de Yahvé, respondió con ingratitud: «¿Así pagáis a Yahvé, pueblo insensato y necio? ¿No es él tu padre, el que te creó, el que te hizo y te fundó?» (Dt 32,6). Los salmos, expresión inigualable del espíritu oracional de un pueblo, son pródigos en llamar a Yahvé con el título de padre. «Como un padre siente ternura por sus hijos, siente el Señor ternura por sus fieles, porque él conoce nuestra masa, se acuerda de que somos barro». (Sal 103,13). «El me invocará: ¡Tú, mi Padre, mi Dios y roca de mi salvación! Y yo haré de él el primogénito, el altísimo entre los reyes de la tierra» (Sal $89,27)$. «Padre de los huérfanos y tutor de viudas, es Dios en su santa morada» (Sal 67,6).

Con los profetas el vocablo Padre adquiere un relieve muy especial. Los

71. ID., o.c., 155.

72. JerEmías, J., El mensaje central del nuevo testamento, Sígueme, Salamanca 1972, 16. 
profetas tienen en la historia de Israel una importancia única. Su misión es siempre consecuencia de una llamada. El profeta es el hombre carismático por antonomasia. Recuerda al pueblo de Dios lo que Yahvé quiere de él y lo hace con frecuencia en un tono agresivo y desencarnado, denunciando particularmente la injusticia y la falsedad de un culto meramente externo.

El centro de la predicación profética es la Alianza llevada a cabo por Dios con su pueblo en el Sinaí. Alianza expresada en estas palabras: "Yo, Yahvé, soy tu Dios, que te he sacado del país de Egipto, de la casa de la servidumbre.

No habrá para ti otros dioses delante de mí» (Ex 20, 2-3). «Escucha, Israel: Yahvé es nuestro Dios, sólo Yahvé. Amarás a Yahvé tu Dios con todo tu corazón, con toda tu alma y con toda tu fuerza» (Dt 6, 4-5).

Los profetas recuerdan al pueblo de Dios ese compromiso adquirido desde los orígenes. $\mathrm{Y}$, por contraste, todo aquello que, de alguna manera, se ha interpuesto y ha impedido su cumplimiento. Fidelidad, por parte de Yahvé, infidelidad, por parte de Israel, son los dos ejes sobre los que gravita parte del mensaje profético. Para hacer más vivo el contraste, los profetas acuden al vocablo Padre, con el que caracterizan a Yahvé, poniéndo así de relieve el amor y la misericordia de Dios por su pueblo. Y, por contraste, la magnitud del pecado del pueblo, al apartarse de quien le había llamado su hijo primogénito y con quien había hecho una alianza de amor. "La mayor parte de las afirmaciones proféticas acerca de Dios como Padre acentúan apasionada y enfáticamente la contradicción que se manifiesta entre la filiación de Israel y su impiedad» ${ }^{73}$.

Patéticas son, desde este contexto, las palabras que Yahvé dirige a los sacerdotes de Israel, denunciando las irregularidades cometidas en los sacrificios: «El hijo honra a su padre, el siervo a su Señor. Pues si yo soy padre ¿dónde está mi honra? Y si Señor ¿dónde mi temor? (Mal 1,6). Con no menor patetismo se expresa el profeta Jeremías, el profeta que con toda seguridad ha vivido más crudamente en su propia carne la magnitud del pecado de Israel: «¿Es que entonces mismo no me llamabas: 'Padre mío’; el amigo de mi juventud eres tú?; ¿tendrá rencor para siempre?; ¿lo guardará hasta el fin? Ahí tienes cómo has hablado; las maldades que hiciste las ha colmado» $(3,4-5)$. «Yo había dicho: 'Sí, te tendré como a un hijo y te daré una tierra espléndida, flor de las heredades de las naciones. Y añadí: 'Padre me llamarás y de mi seguimiento no te volverás» $(3,19)$.

Israel, a pesar de sus infidelidades, conoce muy bien el significado de la paternidad de Yahvé. En ella pone siempre su esperanza. Y a ella acude, cuando quiere arrancar de Yahvé un sentimiento de compasión y de perdón.

73. ID., o.c., 17-18. 
«¿Dónde está tu celo y tu fuerza, la conmoción de tus entrañas? ¿Es que tus entrañas se han cerrado para mí? Porque tú eres nuestro padre, que Abrahán no nos conoce, ni Israel nos recuerda. Tú, Yahvé, eres nuestro Padre, tu nombre es 'El que nos rescata desde siempre'» (Is 63, 15b-16). «Dijo él: 'de cierto que ellos son mi pueblo, hijos que no engañaron'. Y fue él su Salvador en todas sus angustias. No fue un mensajero ni un ángel: él mismo en persona los liberó. Por su amor y su compasión él los rescató; los levantó y llevó todos los días desde siempre» (Is 63, 8-9).

En ocasiones los acentos de ternura son de tal intensidad y están marcados por unas calidades tan tiernas que se acomodan mejor al concepto de madre que de padre. Están aquí presentes los tonos más delicados de un amor que nunca abandona. Yahvé es un Dios dispuesto siempre al perdón y ello en fuerza de un amor constante a su pueblo. «Con lloro partieron y con consuelos los devuelvo, los llevo a arroyos de aguas por camino llano, en que no tropiecen. Porque yo soy para Israel un padre. Y Efraim es mi primogénito (Jer 31,9).

Seguramente es el profeta Oseas quien mejor pone de relieve la ternura y delicadeza de Yahvé por su pueblo. En él alcanza el amor sus más altos quilates maternarles, aunque la terminología usada sea paternalista. Oseas ha vivido con una pasión inusitada una amarga experiencia matrimonial. Ha amado con pasión a una mujer que le ha abandonado. Ello le ha capacitado de forma especial para captar primero el amor de Dios por su pueblo y describir después la tragedia del abandono por parte del pueblo. «Yo enseñé a Efraim a caminar, tomándole en mis brazos... ¿Cómo voy a dejarte, Efraim, cómo entregarte, Israel?» (Os 11, 3.8). «Mi corazón se me revuelve dentro, a la vez que mis entrañas se estremecen. No ejecutaré el ardor de mi cólera, no volveré a destruir a Efraim, porque soy Dios, no hombre; en medio de ti yo el Santo y no me gusta destruir» (Os 11, 8c-9).

Se puede decir de forma general que durante el profetismo es cuando el vocablo 'padre' y lo que tras él se esconde alcanza su más significativa representatividad. Con el término 'padre' los profetas quieren resaltar la paciencia, la comprensión, la ayuda, la acogida sin límites por parte de Dios en relación a su pueblo. Es tan audaz el profetismo en este sentido que llega a proclamar una especie de necesidad divina por lo que respecta a la misericordia y el perdón. La condición paternal de Dios tiene que terminar prácticamente siempre por imponer su perdón y su misericordia. Así suenan las emotivas palabras que el profeta Jeremías pone en los mismo labios divinos: «¿Es un hijo tan caro para mí Efraim, o niño tan mimado, que, tras haberme dado tanto que hablar, tenga que recordarlo todavía? Pues, en efecto, se han conmovido mis entrañas por él; ternura hacia él no ha de faltarme, oráculo de Yahvé» $(31,20)$.

La mística de contenido paternal, tan viva y densa durante el profetismo, 
va a sufrir una cierta quiebra durante el judaísmo palestino. No es que desaparezca. Ella ha marcado muy profundamente la espiritualidad del pueblo de Israel. Pero la desaparición del profetismo va a traer como consecuencia una cierta depauperación. «En toda la literatura de Qumrân, por ejemplo, que tuvo que ser compuesta antes del año 68 p. C., sólo podemos encontrar un pasaje en el que se aplica a Dios el nombre de Padre ( $12 \mathrm{H}$ 9.35s). El judaísmo rabínico utilizó este epíteto algo más libremente, aunque no con mucha frecuencia» ${ }^{74}$.

En cuanto al uso del término 'padre' en esta época hay algo digno de notar. Todos los indicios apuntan a que dicho vocablo tiene siempre carácter colectivo. «Hasta la fecha, dice Joaquín Jeremías, nadie ha mostrado un solo ejemplo en el judaísmo palestino en el que una persona individual se dirija a Dios como 'a mi padre'. Existen unos pocos ejemplos en el judaísmo helenístico, pero se deben a la influencia griega» ${ }^{75}$.

El clima de familiaridad y cercanía, amor y ternura, tipificado o expresado en el término 'padre', adquiere todo su relieve y su expresión más consumada en la obra y en las palabras de Jesús. La conducta y la palabra de Jesús están sustancialmente informadas y animadas del contenido de la palabra $p a-$ dre. Jesús ha expresado todo ello con un término arameo de cadencias muy peculiares. Es el término Abba. Es esto algo peculiar de Jesús. Algo nuevo. "A sus discípulos les debió sonar a algo totalmente extraordinario el hecho de que Jesús se dirigiera a Dios como a 'a mi Padre'. Por otra parte, no sólo los cuatro evangelios atestiguan que Jesús utilizó este tratamiento, sino que ellos refieren unánimemente que lo hizo en todas sus oraciones - (21 veces si se cuentan los paralelos)» ${ }^{76}$. «Por medio de Jesús se reveló Dios como Padre de un Hijo único. Jesús hace comprender que Dios es su Padre en un sentido único por su manera de distinguir 'mi Padre' (p.c. Mt 7,21; 11,27p; Lc 2,49; $22,29)$ y 'vuestro Padre' (p.c. Mt 5,45; 6,1; 7,11; Lc 13,32), de presentarse a veces como 'el Hijo' (Mc 13,32) el Hijo muy amado, es decir, el único (Mc $12,6 \mathrm{p}$; cf. $1,11 \mathrm{p} ; 9,7 \mathrm{p}$ ) y, sobre todo, de expresar la conciencia de una unión tan estrecha entre los dos que él penetra en todos los secretos del Padre y es el único que los puede revelar (Mt 11,25ss)» ${ }^{77}$.

$A b b a$ es una palabra de cadencias infantiles. $A b b a=$ padre e $\operatorname{Im} m a=$ madre son las dos primeras palabras que aprendían los niños de Palestina. Ellas expresan la relación única que existe entre los infantes y sus progenitores. Es una relación dominada por un amor con características peculiares.

74. ID., o.c., 20.

75. ID., o.c., 22 .

76. ID., o.c., 23.

77. Dufour, L., Vocabulario de teología bíblica, Herder, Barcelona 1972, 628. 
Confianza y ternura son dos características sobresalientes de dicho amor. El infante se siente impotente y se confía al $A b b a$ o a la Imma, seguro de que ellos suplirán su impotencia. El $A b b a$ o la Imma abren sus brazos en un gesto grandioso de ternura, mostrando así los sentimientos más profundos de su corazón. De este modo los dos platillos de la balanza, infantes y progenitores, se nivelan de tal forma que vienen a fundirse en una única realidad. Ha desaparecido la distancia, de tal manera que el poder de los padres hace fuertes a los hijos y la impotencia de los hijos hace débiles a los padres.

Jesús, al llamar a Dios con el vocablo de Abba, especialmente en los momentos de oración, está indicando algo que resulta incomprensible para la mentalidad judía: el anonadamiento de un Dios, que no ha escatimado nada para acercarse al hombre. Y, al mismo tiempo, la ternura de un Dios que ha hecho del amor la forma suprema de su relación con el hombre. Al dar a Dios el título infantil de Abba, parece como que Jesús empequeñece a Dios, como que rompe el velo de su majestad. Lo cual adquiere relieve especial en el momento de la oración, por ser ésta la forma más significativa del encuentro con Dios. Jesús ha roto así el clima de distancia entre Dios y el hombre, que presidía aún las relaciones de Dios con su pueblo. Ningún judío se hubiera atrevido nunca a dirigirse a Dios en su oración dándole el título de Abba. Esta costumbre de Jesús era inusual en el ambiente judío. «Ahora ya podemos decir por qué $a b b a$ no se utilizaba en las oraciones judías como un tratamiento aplicable a Dios: en efecto, para una mentalidad judía habría sido irreverente, y por ello impensable, llamar a Dios con esta palabra tan familiar. Y era algo nuevo, algo único e inaudito, el que Jesús se atreviera a dar este paso hablando con Dios como un niño habla con su padre, con simplicidad, intimidad y seguridad. No cabe duda entonces de que el $A b b a$ que Jesús utiliza para dirigirse a Dios revela la base real de su comunión con Dios» ${ }^{78}$.

Al llamar a Dios con el término $a b b a$, Jesús ha creado un nuevo clima para la relación con Dios. Sólo él podía hacerlo por su condición de hijo de Dios y por el conocimiento que tenía de su Padre. De ahí que se pueda decir, sin lugar a dudas, que con la palabra $a b b a$, estamos ante ipssima vox Jesu. «Por una parte, las oraciones judías no contienen ni un solo ejemplo de $A b b a$ como tratamiento aplicado a Dios; y, por otra, Jesús siempre se servía de esa expresión cuando oraba (si exceptuamos la exclamación en la cruz, Mc 15,34). Esto significa que nos encontramos aquí con una inequívoca característica de la manera única como el mismo Jesús se expresaba, de su ipssima vox» ${ }^{79}$.

La forma nueva y sorprendente de relacionarse con Dios, alumbrada y protagonizada por Jesús, al usar la palabra $a b b a$, queda como herencia para

78. JEREMIAS, J., El mensaje central del nuevo testamento, Sígueme, Salamanca 1972, 27.

79. ID., o.c., 25-26. 
sus discípulos. El es el Hijo. Los creyentes en él son los hijos. «Pues a los que de antemano conoció, también los predestinó a reproducir la imagen de su Hijo, para que fuera Él el primogénito entre muchos hermanos» (Rom 8,29). «Los hombres son 'cristianos', no sólo porque hacen profesión de la fe de Cristo, sino ante todo y sobre todo porque están configurados interiormente a imagen del Verbo encarnado, el Hijo de Dios. Son 'hijos de Dios' por estar unidos al Hijo de Dios: Filii in Filio...

Los cristianos están unidos al Verbo encarnado, al 'Hijo de Dios'. Esta unión marca su fisonomía divina con un rasgo filial. No son asimilados a Dios 'de cualquier manera', pudiéramos decir; lo son, porque están configurados a imagen del Hijo de Dios (Rom 8,29). Hechos semejantes al Hijo, son hijos del Padre y están orientados hacia la Trinidad... Nuestra gracia es filial, por semejanza con la filiación misma del Hijo de Dios, y ésta es uno de los elementos constitutivos del misterio por excelencia, el misterio de la Santísima Trinidad» ${ }^{80}$.

Pablo, apóstol y portavoz del misterio de Cristo (Cf. Ef 3,8), nos ha dejado dos textos verdaderamente asombrosos sobre el tema y en ellos se palpa el recuerdo cariñoso del Maestro. El apóstol ha conservado el término usado por el Señor Jesús. «Al llegar la plenitud de los tiempos, envió Dios a su Hijo, nacido de mujer, nacido bajo la ley, para rescatar a los que se hallaban bajo la ley, y para que recibiéramos la filiación adoptiva. La prueba de que sois hijos es que Dios ha enviado a nuestros corazones el Espíritu de su Hijo que clama: i'Abba', Padre! De modo que ya no eres esclavo, sino hijo; y si hijo, también heredero por voluntad de Dios» (Gal 4, 4-7). Muy similar es el texto que nos presenta en la epístola a los Romanos. «Todos los que son guiados por el Espíritu de Dios son hijos de Dios. Pues no recibisteis un espíritu de esclavos para recaer en el temor, antes bien recibisteis un espíritu de hijos adoptivos que nos hace exclamar: ‘'Abba, Padre'! El Espíritu mismo se une a nuestro espíritu para dar testimonio de que somos hijos de Dios» $(8,14-16)$.

Los testimonios paulinos, herencia ya de las comunidades cristianas, manifiestan bien a las claras, no sólo que Pablo ha sintonizado magníficamente con el espíritu de Jesús, sino también cuál debe ser el clima que aliente las relaciones del creyente con Dios. El vocablo 'abba' es lo suficientemente evocativo y nos dice cómo deben transcurrir nuestras relaciones con el Dios y Padre de Nuestro Señor Jesucristo. Simplicidad, intimidad, confianza. Son tres vocablos estupendos para dibujar la relación del creyente con Dios.

Toda la vida del creyente queda bajo el signo del que ve a Dios como $a b$ $b a$. Y al decir toda la vida, se incluyen aquellos acontecimientos que, a prime-

80. THILS, G., Santidad cristiana, Sígueme, Salamanca 1964, 86-87. 
ra vista, pueden resultar extraños y hasta escandalosos. En esta línea suenan las palabras de la primera carta de Pedro. «Confiadle todas vuestras preocupaciones, pues él cuida de vosotros» $(5,7)$. Y también estas palabras que el evangelista Lucas pone en labios del mismo Jesús: «No temas, pequeño rebaño, porque a vuestro Padre le ha parecido bien daros a vosotros el reino» $(12,32)$.

Si toda la vida del creyente en Jesús queda bajo el signo del $a b b a$, ello sucede de forma privilegiada en el tiempo de oración. La oración es por su misma condición el momento más relevante del encuentro con Dios, con el Dios de Jesús. Dirigirse a ese Dios con el título de abba, como lo hacía Jesús, es lo mismo que confesar que ese Dios es para el orante ante todo y sobre todo presencia vida de amor, intimidad y confianza. En la oración se percibe con intensidad muy particular que «tanto amó Dios al mundo, que le dio a su Hijo único, para que todo el que crea en él no perezca, sino que tenga vida eterna» $(\mathrm{Jn} 3,16)$. La oración nos lleva al convencimiento de que los designios de Dios sobre el hombre son designios de salvación, no de condenación. «Si Dios está por nosotros, ¿quién contra nosotros? El que no perdonó ni a su propio Hijo, antes bien lo entregó por todos nosotros, ¿cómo no nos dará con él graciosamente todas las cosas? ¿Quién acusará a los elegidos de Dios? Dios es quien justifica, ¿Quién condenará? ¿Acaso Cristo Jesús, el que murió; más aún, el que resucitó, el que está a la diestra y que intercede por nosotros?

¿Quién nos separará del amor de Cristo? ¿La tribulación? ¿La angustia? ¿La persecución? ¿El hambre? ¿La desnudez? ¿Los peligros? ¿La espada?... En todo esto salimos vencedores gracias a aquel que nos amón (Rom 8, 31-37).

La oración, vivida en el espíritu de Jesús, es la mejor forma de sentir la experiencia de un Dios que quiere ser esto y nada más: $a b b a$. La oración, vivida en el espíritu de Jesús, destroza nuestros mecanismos de defensa y, sobre todo, rompe el cerco de nuestro egoísmo, empujándonos al encuentro de los demás en una vivencia profunda de la fraternidad. Dicha oración debe culminar en la identificación con los estados afectivos y efectivos del hermano. «¿Quién desfallece, sin que desfallezca yo? ¿Quién sufre escándalo, sin que yo me abrase?» (2 Cor 11,29). Así se expresa Pablo, seguramente uno de los hombres de fe que ha vivido más intensamente la experiencia oracional del $a b$ $b a$. Y así debe expresarse todo aquel que sigue sus pasos y ora con su mismo espíritu. Quien vive la oración en el espíritu de Jesús asume necesariamente el compromiso de entregarse a los demás y entregar hasta su propia vida en beneficio de los hermanos. «En esto hemos conocido lo que es el amor: en que él (Jesús) dio su vida por nosotros. También nosotros debemos dar la vida por los hermanos» $(1 \mathrm{Jn} 3,16)$. La oración en el espíritu de Jesús nunca puede terminar en una actitud alienante. Nunca puede impedir que el hombre sea ante 
todo hombre: solidario y comprometido con todos los demás hombres. El camino de la oración en el espíritu de Jesús es el mejor medio de conseguir un mundo mejor, porque hace que el hombre muera al pecado y viva para el amor.

¡Morir y vivir! Es el doble movimiento de todo proceso de conversión. Por eso, la oración en el espíritu de Jesús se traduce en una actitud de constante conversión. Es imposible para el que ora en el espíritu de Jesús permanecer bajo el dominio del pecado. Nadie mejor que el orante puede captar, desde la experiencia oracional del Dios- $a b b a$, el abismo insondable de la malicia del pecado y la necesidad de luchar contra él. Sólo a la luz de la oración aparece el pecado en toda su magnitud como realidad opuesta al plan salvífico de Dios y realidad empobrecedora de la misma condición humana. El amor a Dios, percibido en la oración como experiencia del $a b b a$, conlleva la superación del pecado. De este modo, la oración se constituye en elemento fundante y sustancial de una conversión permanente. Nadie mejor que el orante sabe que su única alternativa es optar por el amor. Amor que encuentra su consumación en el cumplimiento de la voluntad de Dios. «No todo el que me diga: 'Señor, Señor' entrará en el Reino de los cielos, sino el que haga la voluntad de mi Padre celestiall» (Mt 7,21). «En esto consiste el amor a Dios: en que guardemos sus mandamientos» (1 Jn 5,3a).

La oración en el espíritu de Jesús, la oración de la experiencia del $a b b a$, es con toda seguridad la mejor escuela del amor misericordioso de Dios. Y, por tanto, el mejor instrumento para llevar dicho amor misericordioso a todos los hombres. Sólo quien experimenta el amor misericordioso puede ser apóstol del mismo. Y sólo quien experimenta el amor misericordioso de Dios puede liberarse del peso del pecado. O lo que es lo mismo, sólo quien experimenta el amor misericordioso de Dios puede alentar en sí y en los demás un auténtico - sentimiento de conversión. «El auténtico conocimiento de Dios, Dios de la misericordia y del amor benigno, es una constante e inagotable fuente de conversión, no solamente como momentáneo acto interior, sino también como disposición estable, como estado de ánimo. Quienes llegan a conocer de este modo a Dios, quienes lo 'ven' así, no pueden vivir sino convirtiéndose sin cesar a Él. Viven, pues, in statu conversionis; es este estado el que traza la componente más profunda de la peregrinación de todo hombre por la tierra in statu viatoris $^{81}$.

La condición pecadora del hombre, reconocida y valorada desde la experiencia del amor misericordioso vivido en la oración en el espíritu de Jesús, sitúa la convivencia humana en un campo muy concreto. Precisamente porque

81. JuAn Pablo II, Dives in misericordia, PPC, Madrid 1980, 67. 
el hombre siente la necesidad de perdón, única forma de superar el peso del pecado, puede sentir también la necesidad de conceder el perdón. Supondría un contrasentido excesivamente contradictorio palpar la necesidad del perdón por parte de Dios y negar ese perdón a los demás. Esta óptica es la única que puede dar un nuevo contenido a las relaciones humanas. Estas relaciones ya no se medirán sólo por la justicia, inconveniente que nos acecha hoy particularmente, sino que se abrirán al soplo de la misericordia, que es, con mucho, más amplio y más flexible. «El mundo de los hombre puede hacerse "cada vez más humano', solamente si en todas las relaciones recíprocas que plasman su rostro moral introducimos el momento del perdón, tan esencial al evangelio. El perdón atestigua que en el mundo está presente el amor más fuerte que el pecado. El perdón es además la condición fundamental de la reconciliación, no sólo en la relación de Dios con el hombre, sino también en las recíprocas relaciones humanas. Un mundo, del que se eliminase el perdón, sería un mundo de justicia fría e irrespetuosa, en nombre de la cual cada uno reivindicaría sus propios derechos respecto a los demás; así los egoísmos de distintos géneros, adormecidos en el hombre, podrían transformar la vida y la convivencia humana en un sistema de opresión de los débiles por parte de los más fuertes o en una arena de lucha permanente de los unos contra los otros» ${ }^{82}$.

Si no interpreto mal el mundo moderno, y desde luego no quiero hacerlo desde una óptica pesimista, me parece que se puede hablar de un mundo cansado por y decepcionado de tantas promesas liberacionistas. Ello se debe principalmente a que se ha puesto el acento casi con exclusividad en el cambio de estructuras, mientras ha quedado marginado el cambio del corazón. Las estructuras ciertamente son importantes. Pero, a la larga, lo definitivo es el corazón. Si se cambian aquéllas y no se cambia éste, lo que suele acontecer es que siempre impera el egoísmo. Y, de la mano del egoísmo, no es posible llevar a cabo ninguna mejora sustancial humana. Los dictadores cambian de signo, pero siguen siendo dictadores. Para que esto no acontezca, es necesario que el hombre cambie el corazón, de forma que se despoje de sus mecanismos de poder. Y, desde ahí, es preciso que no tanto la justicia como la misericordia impongan su ley. Al saberse todos necesitados de perdón, es más fácil ofrecer el perdón.

La conversión del corazón es para el creyente en Jesús fruto de la gracia más que del esfuerzo humano. Es necesario suplicarla ardientemente. La oración en el espíritu de Jesús, a través de la cual se experimenta la misericordia de Dios, es el instrumento por antonomasia de dicha conversión. Quien experimenta a Dios como amor misericordioso no podrá por menos de sentir la ne-

82. ID., o.c., 73. 
cesidad de ser apóstol de tal amor. Y no podrá por menos de vivir frente a los demás la experiencia de tal amor. De ahí que la oración en el espíritu de Jesús es la mejor forma de colaborar a la construcción de un mundo que se estructure en base al amor.

Para terminar estas reflexiones sobre la especificidad de la oración cristiana, es preciso afirmar con tono alto que la oración es un elemento fundamental en la vivencia del mensaje de Jesús. Cualquier engaño sobre el tema, aunque tenga apariencia religiosa y, hasta cierto punto, evangélica, produce estragos irreparables en la relación del creyente con Dios. Sólo en la oración se nos descubre de forma privilegiada el rostro de Dios y nuestra propia condición humana. «Para nosotros el hombre no se define a partir del uso de ciertos instrumentos o desde la posibilidad de cambiar el ambiente en que se vive. $\mathrm{Ni}$ siquiera es suficiente la definición de homo sapiens. Se define como homo orans, en cuanto que adora, escucha y responde a Dios, confiriendo verdad a su propia existencia. Sin oración el hombre no llega a la verdad ni descubre su nombre» ${ }^{83}$. Lo cual significa que sin oración el hombre no llega a ser plenamente hombre. Tal vez esto sea un tanto excesivo, sobre todo si queremos valorar en su justo medio la persona y el posible testimonio en favor de los demás, de los que se confiesan hombres ateos o agnósticos. Con el máximo respeto que estas personas merecen y sin querer descalificar en lo más mínimo su persona y su conducta, es necesario proclamar que el hombre sólo adquiere su verdadera dimensión desde Dios. "La criatura sin el Creador se esfuma» ${ }^{84}$. Y esto atañe también para quienes, desde una conciencia correcta, se entregan al servicio de los demás y luchan por un mundo en que impere el amor y la justicia. Sin saberlo, ellos también reciben la luz de Dios. «Cristo murió por todos, y la vocación suprema del hombre en realidad es una sola, es decir, divina. En consecuencia, debemos creer que el Espíritu Santo ofrece a todos la posibilidad de que, en forma de sólo Dios conocida, se asocien a este misterio pascual» ${ }^{85}$.

Los seguidores de Jesús tienen el compromiso sagrado de ofrecer al mundo su persona y su trabajo, para que el mundo crezca y se desarrolle en la línea de ser cada vez más un mundo más humano y fraterno. En el cumplimiento de ese compromiso el seguidor de Jesús no puede olvidar su condición religiosa. $Y$, desde ésta, su vertiente oracional. Seguramente que en esta vertiente oracional se halla lo más característico del aporte cristiano. El servicio al hombre del seguidor de Jesús está clamando por una vivencia intensa del encuentro con Dios hecha carne viva en la oración. Orar para el cristiano no sólo es una

83. Haering, B., Oración. Nuevo diccionario de espiritualidad, Ed. Paulinas, 1015.

84. VATICANO II, GS. 36c.

85. Vaticano II, GS. $22 \mathrm{f}$. 
necesidad de su crecimiento interior, sino que es también un imperativo de su contribución a la construcción de un mundo mejor. "Seguramente muchos cristianos no han caído en la cuenta de la significación que tiene la oración en la vida del creyente y, más en concreto, en el testimonio y el compromiso que los creyentes tenemos que realizar en el mundo, precisamente en nuestro empeño por conseguir una sociedad más humana y más justa. Cuando un hombre se aparta de los demás hombres, cuando deja sus ocupaciones y se entrega a la oración, en el fondo está expresando, de la forma más elocuente, que lo importante en la vida no es lo que el hombre tiene, sino lo que el hombre es...

Decididamente, si el testimonio de los cristianos no es también testimonio de oración, poco tiene qụe decir este testimonio en este mundo. Es más, ¿no ha llegado ya la hora de decir a este mundo que el estilo nuestro es un estilo diferente, el estilo que procede de la plegaria y se expresa no sólo en el compromiso, sino además en la contemplación?... Ofrecer en este tiempo una alternativa real es decir con hechos que lo importante no está en tener, sino en ser. Y se trata de ser cristianos hasta la última fibra del ser» ${ }^{86}$. Se trata de ser cristianos hasta la última fibra de nuestro ser. He aquí la tarea insoslayable, nacida de nuestra incorporación a Cristo por el bautismo y de nuestra opción de vida por el seguimiento de Jesús como razón última de nuestra existencia. Para llegar ahí, el camino por antonomasia es el camino de la oración vivida como encuentro y como experiencia del abba. "Sin oración el hombre no llega a la verdad ni descubre su nombre. Nuestra exitencia es un don. Somos llamados por la palabra creadora de Dios, y esta palabra es una invitación a vivir conscientemente en su presencia. Viviendo a través de la llamada que nos da la vida, podemos encontrarnos en la escucha y en la respuesta a quien nos da un nombre único y todo lo que somos. No podemos encontrar nuestra identidad más que volviéndonos a Dios, que es origen y fin de nuestra vida» ${ }^{87}$.

\section{AGUSTÍN MODELO DE ORACIÓN}

Antes que maestro de oración, Agustín es modelo de oración. O, si se quiere, más bien se puede decir: Agustín es maestro de oración, porque ha querido y ha sabido, bajo el impulso del Espíritu Santo, ser un orante perfecto. Su palabra, al respecto, no sólo es palabra de un sabio, sino palabra de un santo. De ello no se puede dudar. Si alguno se permite la duda, puede salir fácilmente de ella con sólo leer el libro religiosamente más significativo de Agustín: Las Confesiones. Una oración abre sus páginas. Y con una oración se cie-

86. CAStillo, J.M., La alternativa cristiana, Sígueme, Salamanca 1978, 225.

87. HaEring, B., Oración. Nuevo diccionario de espiritualidad, Ed. Paulinas, 1015-1016. 
rra su mensaje. « $¡$ Grande eres, Señor, y muy digno de alabanza! ¡Grande es tu poder y tu sabiduría no tiene medida!

Y pretende alabarte un hombre, pequeña migaja de tu creación. Precisamente un hombre que lleva en torno suyo la mortalidad, que lleva a flor de piel la etiqueta de su pecado y el testimonio de tu resistencia a los soberbios.

A pesar de todo, pretende alabarte un hombre, pequeña migaja de tu creación. $Y$ eres tú mismo quien le estimula a que halle satisfacción alabándote, porque nos ha hecho para ti y nuestro corazón está inquieto hasta que descanse en ti» ${ }^{88}$.

«Algunas de nuestras obras son buenas por ser don tuyo,pero no son eternas. Después de ellas esperamos descansar en tu gran santificación. Pero tú, que eres el bien que no tiene necesidad de ningún otro bien, siempre estás en reposo, porque tú mismo eres tu reposo.

¿Qué hombre puede dar esto a entender a otro hombre? ¿Qué ángel, a otro ángel? A ti hay que pedírtelo, en ti hay que buscarlo, a tu puerta hay que llamar. Así, se obtendrá, así se hallará, así se nos abrirá» ${ }^{89}$.

Cada página de Las Confesiones constituye un brillante pentagrama de su sinfonía oracional. Agustín habla de su vida, del desarrollo de la misma, de su aciago y épico caminar, teniendo siempre como interlocutor a Dios. Éste está siempre presente a lo largo de sus prolongados discursos. Si se quitara, por hipótesis, de Las Confesiones esa referencia a Dios, perderían lo más valioso de su mensaje. Las Confesiones son, antes que nada, una fervorosa oración. En ellas Agustín no se cansa de cantar las maravillas de Dios, de admirar el misterio de su amor hacia los hombres y de expresar oracionalmente los sentimientos más variados de su inmenso tesoro religioso. Es con toda seguridad en esta obra en donde Agustín manifiesta su esclarecida condición de hombre orante. Y, por eso, a ella hay que recurrir de forma particular para captar al Agustín orante, al Agustín modelo de oración. Es ésta la forma mejor de descubrir el espíritu de Agustín y de sentir su presencia vivificadora en nuestra vida. En Las Confesiones encontramos al Agustín más genuino, pues, aunque el genio de Agustín es polivalente, se manifiesta, antes que nada, en el ámbito religioso. Agustín es, sobre todo, un honbre religioso, en quien el Dios y Padre de nuestro Señor Jesucristo ha entrado tan profundamente y tan decisivamente que lo invade y lo llena hasta rebosar.

«Lo divino es la atmósfera propia del genio de san Agustín, porque en el universo creado sólo ve vestigios, sombras, guiños de la Sabiduría infinita, que le hacen volver y subir a la Causa suprema y ejemplar de cuanto existe.

La idea de Dios ilumina la concepción agustiniana del mundo. No sólo

88. San Agustín, Conf. Lib. $1,1,1$.

89. ID., o.c., 13,38,53. 
por interés religioso, sino también por razones metafísicas, el problema de Dios es central en su filosofía, como áncora del pensamiento y del corazón. El sentido del mundo, el valor de la personalidad humana y hasta los problemas del conocimiento y de la cultura reclaman el apoyo de Dios... Conocer a Dios es la más dichosa y provechosa ocupación del espíritu, porque Él es el valor de los valores, el sumo bien, en quien se aquieta el corazón humano. La dialéctica de la cultura agustiniana se halla movida interiormente por este impulso de conocimiento de Dios, que es un impulso sotereológico o de salvación del alma, es decir, el más hondo impulso que submueve el corazón humano» ${ }^{90}$.

Agustín suspira por Dios día y noche. En la noche de su lejanía de Dios y en el día luminoso de su encuentro con Dios, cuyo hito más importante fue su conversión. Y lo hace casi siempre con acentos tan tiernos que parecen más propios de un espíritu femenino que masculino. Una ternura quejumbrosa satura muchas de sus manifestaciones. En esto particularmente Las Confesiones han logrado una altura de no fácil superación. «¿Quién podrá concederme que yo repose en ti? ¿Quién me concederá que vengas a mí corazón y lo embriagues para que me olvide de todos mis males y me abrace contigo, único bien mío?

¿Qué eres tú para mí? Ten misericordia de mí para que me salgan las palabras. ¿Qué soy yo para ti, que llegas a ordenarme que te ame, y si no lo hago te disgustas conmigo y me amenazas con grandes desgracias? ¿Es que no es suficiente desgracia la de no amarte? ¡Ay de mí! Por tu ternura te pido que me digas qué eres tú para mí. Dile a mi alma: Yo soy tu salvación. Y dilo de tal modo que yo lo oiga. Señor, ahí tienes en tu presencia los oídos de mi corazón. Ábrelos y dile a mi alma: Yo soy tu salvación. Yo saldré disparado tras de esta voz y te alcanzaré. ¡No me escondas tu rostro! Que yo muera para no morir, a fin de que vea tu rostro» ${ }^{91}$.

Agustín recorre las distintas etapas de su vida, construyendo así sus Confesiones, en diálogo tierno con Dios. Mientras lo hace, reconoce y admira la grandeza del Señor, al par que expresa la sorprendente pequeñez del hombre. Es como un díptico compuesto de dos temas contrapuestos: la grandeza de Dios y la pequeñez del hombre. Ambos se iluminan mutuamente. La grandeza de Dios se ensancha ante la pequeñez del hombre. La pequeñez del hombre se encoje ante la grandeza de Dios. Y en un movimiento opuesto también se puede decir: la grandeza de Dios se empequeñece ante la pequeñez del hombre y la pequeñez del hombre se ensancha ante la grandeza de Dios. Agustín descubre muy pronto la grandeza de Dios. «Vi que había personas que te invocaban. De

90. Capánaga, V., Introducción general a las obras de S. Agustín, BAC, Madrid 1946, 71.

91. San Agustín, Conf. Lib. 1,5,5. 
ellas aprendí, dados mis cortos alcances, que tú eres alguien, que eres grande y que puedes escucharnos y apoyarnos, aunque no te manifiestas a nuestros sentidos. Niño como era, comencé a implorarte, auxilio y refugio mío, y, al invocarte, rompía las trabas de mi lengua» ${ }^{92}$.

Desde la cercanía de Dios, desde su luz deslumbrante y desde su grandeza sin límites, Agustín descubre la pequeñez del hombre. Sobre todo, profundiza en la miseria moral del hombre. Tal vez sea éste uno de los puntos más negros y desafortunados de la antropología agustiniana. Agustín es pesimista por lo que respecta a su visión del hombre. Agustín descalifica moralmente lo que son simplemente mecanismos de defensa al servicio de una supervivencia siempre amenazada. Es posible que en ello influya su propia experiencia posterior. Una experiencia sobre la que él ejerce juicios morales de valor excesivamente descalificadores. Respecto a la carne nunca pudo Agustín superar sus resabios maniqueos. De ahí que sus expresiones sobre el tema resultan siempre extrañas y, en ocasiones, rechazables. Agustín habla de sus travesuras de la infancia en los términos siguientes: "Yo seguía pecando, Señor y Dios mío, ordenador y creador de todos los seres que existen en la naturaleza, pero de los pecados nada más que ordenador. Yo seguía pecando, Señor Dios mío, actuando contra las órdenes de mis padres y de aquellos maestros. Podían serme de provecho para el día de mañana aquellas letras que ellos fuera cual fuese su intención, pretendían que aprendiese yo. Mi desobediencia no se basaba en una opción personal por lo mejor, sino en la afición al juego ${ }^{93}$. Haciendo una especie de síntesis de esta primera etapa de su vida y haciéndola en forma de oración, Agustín, se expresa así: «¿Hay algo en este ser animado que no sea digno de admiración y alabanza? Todos ellos son dones de Dios, yo no me los di. Todo esto son bienes, y todo esto soy yo. Por consiguiente, el que me creó es bueno, él es mi bien, y salto de gozo en su honor por todos los bienes por los cuales yo era niño.

Pero pecaba en una cosa: en la búsqueda de placeres, honras y verdades no en Dios, sino en las criaturas: en mí y en las demás. Por eso, incurría en dolores, confusiones y errores.

Gracias, dulzura mía, honor mío, confianza mía, Dios mío; gracias por tus dones. Sigue conservándomelos. De este modo me guardarás a mí, y los dones que me hiciste se verán incrementados y perfeccionados. Y yo estaré contigo, porque mi misma existencia es un don tuyo $>{ }^{94}$. De esta forma tan delicada, con una oración cargada de sentimientos y afectos, Agustín canta y ad-

92. ID., o.c., 1,9,14.

93. ID., o.c., $1,10,16$.

94. ID., o.c., $1,20,31$. 
mira la grandeza de Dios y su bondad. Al mismo tiempo, se confiesa pecador por el mal uso de los dones divinos.

El año décimo-sexto de su vida constituye un hito importante en la vida de Agustín. En él acontecen muchas y definitivas cosas. Agustín las recuerda con pasión. En este año tiene que interrumpir los estudios en Madaura, ciudad cercana a Tagaste, en donde se encontraba por entonces estudiando Literatura y Oratoria. Al problema de la edad se une ahora el no menos problema de la ociosidad. El desarrollo biológico y el ambiente contribuyen a crear una situación moral que Agustín examina y analiza rigurosamente. «A mis dieciséis años, cuando por razones económicas me tomé unas vacaciones forzosas en casa de mis padres, es cuando cobraron vigor y medraron por encima de mi cabeza las zarzas de mis pasiones» ${ }^{95}$. Las malas compañías, el juego y el hurto se suman a ese clima de lascivia que, por entonces, le domina. Agustín se siente perdido en la inmensidad de un océano que lo azota con sus olas violentas. Son unos momentos realmente difíciles. Agustín los recuerda con amargura, al tiempo que eleva una fervorosa oración a Dios. «¿Quién será capaz de desatar este nudo tan complicado y ciego? Es feo; no quiero ni mirarlo. No quiero examinarlo. Te quiero a ti, justicia e inocencia, que eres hermosa y digna, adornada de luces puras y de una saciedad insaciable. En ti se halla el perfecto descanso y una vida imperturbable. El que se adentra por tus puertas penetra en el gozo de su Señor sin recelo alguno, y se hallará extraordinariamente bien en el sumo Bien.

Yo, por mi parte, me alejé de ti y anduve errante, Dios mío, en tus caminos, durante mi adolescencia, demasiado desviado de la estabilidad que me proporcionabas, y me convertí en un paraje miserable» ${ }^{96}$.

La miseria moral, que padece por estos años, culmina en su etapa de Cartago. Cartago es por entonces una ciudad importante dentro del imperio romano. A ella acude Agustín para proseguir sus estudios. Es su ilusión, como es la ilusión de todo provinciano. Estudiar en Cartago supone disfrutar de muchas ocasiones de triunfo. Cartago es, por lo demás, una ciudad semipagana, excesivamente liberal en sus costumbres. "La gran ciudad, saturada de un perfume lascivo y tentador, pronto sedujo al forastero. Se despertó en él la afición al teatro, que era una de las distracciones favoritas de los cartagineses» ${ }^{97}$. Agustín retrata así su llegada a Cartago: «Llegué a Cartago y a mi alrededor chirriaba por doquier aquella sartén de amores depravados... Andaba a la búsqueda de un objeto de amor, deseoso de amar. Me asqueaba la seguridad, y me aburría el camino sin trampas» ${ }^{98}$.

95. ID., o.c., $2,3,6$.

96. ID., o.c., $2,10,18$

97. CAPÁnAGA, V., Introducción general a las obras de S. Agustín, BAC, Madrid 1946, 7.

98. San Agustín, Conf. Lib. 3,1,1. 
La situación moral se agrava en esta época por la situación intelectual. La lectura del libro de Cicerón «El Hortensio», un libro que exhorta vehementemente a la búsqueda de la sabiduría, le enciende y le entusiasma. Produce en Agustín un cambio decisivo. «Su lectura realizó un cambio en mi mundo afectivo. También encaminó mis oraciones hacia ti, Señor, e hizo que mis proyectos y deseos fueran otros. De golpe todas mis espectativas de frivolidad perdieron crédito, y con increíble ardor de mi corazón ansiaba la inmortalidad de la sabiduría. Y comencé a levantarme para iniciar el retorno a ti» ${ }^{99}$.

Desde este momento la búsqueda apasionada de la Verdad se constituye en una especie de segunda naturaleza de Agustín. Ciertamente se puede, equivocar. Ciertamente puede errar el camino. Pero la brújula de su espíritu no deja ya de apuntar hacia el norte de la Verdad, hacia Dios. Tarde o temprano Agustín encontrará lo que con tanta pasión comienza a buscar desde su lectura del Hortensio. Programáticas son al respecto estas palabras: «Qué ardor sentía, ¡Dios mío, qué ganas tenía de remontar el vuelo hacia ti desde las realidades terrenas, sin darme realmente cuenta de lo que estabas haciendo conmigo! Porque de hecho en ti tiene su morada la sabiduría, y este amor a la sabiduría recibe en griego el nombre de filosofía. Aquel tipo de literatura me iba enardeciendo de ese amor» ${ }^{100}$.

Ansioso de la sabiduría, eterno peregrino de la verdad, buscador incansable de Dios, Agustín inicia por entonces un largo y trepidante caminar. En la base de toda esta febril actividad intelectual y vital está la conquista de la Verdad. Dada su educación cristiana de la infancia, Agustín se pone en contacto con La Sagrada Escritura. Afectivamente no está preparado para una lectura provechosa. No entiende su contenido y le decepciona, sobre todo, su lenguaje rudo. Su estilo le resulta pobrísimo en comparación con el estilo elegante de Cicerón. Tampoco le convence por entonces tener que aceptar muchas cosas de la Biblia en base simplemente al argumento de autoridad. Agustín padece el inconveniente de un mal entendido racionalismo. Quiere entenderlo todo y aceptar sólo lo que entiende.

Alguien iba a llamar a sus puertas, prometiéndole precisamente lo que Agustín pide en este momento. Se trata de los maniqueos. Éstos le prometen la verdad. Pero la verdad no impuesta por autoridad, sino aceptada por convicción y pasada por el filtro de la razón. Agustín se ilusiona con la propuesta. Le ofrecen lo que él espera en aquel preciso momento. No se puede pedir más. Es una respuesta a la medida de su inquietud. Más tarde se lamentará del engaño a que fue sometido. Los maniqueos defraudan clamorosamente sus ofertas. Nada o muy poco de verdad y nada, sobre todo, de verdad ofrecida y

99. ID., o.c., 3,4,9.

100. ID., o.c., $3,4,8$. 
aceptada racionalmente. Agustín se refiere a ese momento en términos verdaderamente dramáticos: «Así que vine a caer en manos de unos hombres de orgullo delirante, carnales y charlatanes a más no poder. En su boca sólo había trampas diabólicas y una especie de liga pegajosa confeccionada a base de sílabas de tu nombre, del de nuestro Señor Jesucristo y del Espíritu Santo Paráclito, consolador nuestro. Estos nombres no se apeaban de sus labios, pero no pasaban de ser meros sonidos articulados de la boca y de la lengua.

Por lo demás, su corazón estaba huero y vacío de verdad. Y repetían machaconamente: verdad, verdad» ${ }^{101}$.

La sola presencia de la palabra verdad conmueve las entrañas de Agustín. Y a ella se dirige con los requiebros de un enamorado: « $; A y$ Verdad, Verdad! ¡Cuán íntimamente suspiraban por ti en aquel entonces las fibras más íntimas de mi corazón, cuando aquellos hombres repetían a mis oídos, frecuentemente y de mil maneras, los ecos de tu nombre, primero sólo de palabra y luego en numerosos y gigantescos libros!» ${ }^{102}$.

La situación deplorable en que ha caído le hace estallar en delicadas tonadas de oración. Se extraña de verse lejos de Dios, al tiempo que, recordando al hijo pródigo, se ve privado de las miserables bellotas que pudieran saciar sus instintos de placer. Con acento dolorido se dirige a Dios y le pregunta: «¿Dónde estabas entonces respecto de mí? ¡Ay qué lejos! Vagabundeaba yo por lejanas tierras, apartado de ti y privado de las mismas bellotas de los cerdos que yo apacentaba con bellotas» ${ }^{103}$. Consciente de su deplorable situación, se lamenta dolorido del abismo de miseria en que ha caído por causa de sus pecados. Con gritos de desgarrado dolor dirige su oración a Dios en una interpelación de tonalidades femeninas: «iPobre de mí! ¡Por qué escalones fui descendiendo hasta las profundidades del infierno! Estaba enfermo y ardía de fiebre debido a una insuficiencia de verdad cuando te buscaba, Dios mío -reconozco que me llegó tu compasión cuando aún no te confesaba-, cuando te buscaba no siguiendo las directrices del entendimiento racional con que quisiste diferenciarme de las bestias, sino según el sentido carnal. Pero tú me eras más íntimo que mi propia intimidad y más alto que lo más alto de mi ser» ${ }^{104}$.

Una serie de factores, entre los que hay que contar el crudo dualismo maniqueo, la incoherencia de unos hombres que prometieron no imponer nada y ahora lo imponen todo, el encuentro decepcionante con el famoso Fausto, la constante preocupación y oración de Mónica, van enfriando el primitivo fer-

101. ID., o.c., 3,6,10.

102. ID., o.c., $3,6,10$.

103. ID., o.c., $3,6,11$.

104. ID., o.c., $3,6,11$. 
entre todo tipo de opiniones, tomé la resolución de abandonar a los maniqueos. Pensaba que, mientras siguiera el proceso de mi duda, no debía permanecer en aquella secta, pues ya en mi estima personal anteponía a ella el sentir de algunos filósofos. Sin embargo, tampoco a éstos, desconocedores del nombre saludable de Cristo, quería confiar en términos absolutos la curación de mi alma.

En consecuencia, a la espera de que surgiese algo seguro adonde encaminar mis pasos, tomé la resolución de ser catécumeno en la Iglesia católica, que me había sido recomendada por mis padres» ${ }^{107}$.

En este preciso momento, seguramente el más angustioso del siempre duro caminar de Agustín hacia su conversión, vuelve a surgir como algo definitivo la acción de Mónica. Abandonada de su hijo en su patria, Mónica no pierde la esperanza de poder estar a su lado. Desde luego, uno se queda perplejo ante la intrepidez de esta mujer. No es nada fácil la empresa de trasladarse de África a Italia. ¿Cómo consiguió Mónica el dinero suficiente para hacer este viaje arriesgado? No lo sabemos. Lo cierto es que Mónica se encuentra por entonces al lado de su hijo. Agustín lo testifica entre perplejo y asombrado: «Ya había llegado y se hallaba conmigo mi madre, siguiéndome por tierra y por mar, con su piedad llena de bríos, segura de ti en todos los peligros...

A mí me encontró en una situación realmente crítica, cuando ya desesperaba de dar con la verdad» ${ }^{108}$.

La situación crítica evoluciona favorablemente. La presencia, la oración y la palabra de Mónica, que no ahorra esfuerzo a su alcance para conseguir la vuelta de su hijo al redil, golpean fuertemente el espíritu de Agustín y lo impulsan a seguir caminando sin descanso. Agustín había hecho sustanciosos progresos en el campo de la razón. Hechas ya muchas jornadas de camino, su entendimiento se va desligando poco a poco de aquellos impedimentos que le obstaculizan en la conquista de la verdad. Por este tiempo Agustín tiene ya algunas cosas muy claras. «Así me vi libre de aquellas ataduras gracias a ti, ayudador mío. Seguía investigando el origen del mal, pero sin llegar a resultado alguno. Tú no me permitías que el oleaje de mis reflexiones me arrancase de aquella fe por la que creía que tú existes, que tu esencia es inmutable y que tienes providencia de los hombres. Creía en tu justicia. Creía que has puesto el camino de la salvación humana en Cristo, tu Hijo, Señor nuestro, y en las santas Escrituras, avaladas por la autoridad de tu Iglesia. Esta salvación de la humanidad está encaminada hacia aquella otra vida que tendrá lugar después de la muerte» ${ }^{109}$.

107. $5,14,25$.

108. ID., o.c., $6,1,1$.

109. ID., o.c., $7,7,11$. 
En esta situación de espíritu, con un avance muy sustancioso en el camino de la verdad, Agustín tiene la fortuna de topar con unos escritos neoplatónicos. La lectura de estos libros supone un paso de gigante en el camino de la definitiva conversión de Agustín. Con ellos Agustín se va a purificar de una serie de prejuicios que le impedían pensar rectamente de muchas cosas. El conocimiento de los neoplatónicos purifica a Agustín de aquel materialismo burdo, herencia del maniqueísmo, que le impedía incluso pensar en los seres inmateriales. Le ayuda, al mismo tiempo, a encontrar una solución al problema del mal, que él consideró acertada. Con lo que logra dejar a un lado una de las cuestiones que más le habían inquietado. «Son buenas todas las cosas que son. $\mathrm{Y}$ el mal, cuyos orígenes andaba investigando, no es una sustancia, porque, si fuera sustancia, sería un bien. No cabría más que este dilema: tendría que ser o sustancia incorruptible - un gran bien, sin duda - o sustancia corruptible. Ahora bien, ésta no podría corromperse, si no fuera buena» ${ }^{110}$.

La lectura de los neoplatónicos abre a Agustín un sendero luminoso que le va a permitir descubrir en el fondo de su ser interior la luz inconmutable. Agustín habla de esta experiencia en términos verdaderamente apasionados. Es difícil distinguir aquí quien habla más, si la razón o el corazón. La balanza parece inclinarse por este último. «Ante la sugerencia de aquellos escritos que me intimaban al retorno a mí mismo, penetré en mi intimidad, siendo tú mi guía. Fui capaz de hacerlo, porque tú me prestaste asistencia. Entré y vi con el ojo de mi alma, tal cual es, sobre el ojo mismo de mi alma, sobre mi inteligencia, una luz inmutable. No esta luz vulgar y visible a toda carne ni algo por el estilo. Era una luz de potencia superior, como sería la luz ordinaria si brillase mucho y con mayor claridad y llenase todo el universo con su esplendor. Nada de esto era aquella luz, sino algo muy distinto, algo muy diferente de todas las luces de este mundo.

Tampoco se hallaba sobre mi mente como el aceite nada sobre el agua, ni como está el cielo sobre la tierra. Estaba encima de mí, por ser creadora mía, y yo estaba debajo por ser hechura suya. Quien conoce la verdad, la conoce, y quien la conoce, conoce la eternidad.

¡Oh eterna verdad, verdadera caridad y amada eternidad! Tú eres mi Dios. Por ti suspiro día y noche. Cuando te conocí por vez primera, tú me acogiste, para que viese que había algo que ver y que yo no estaba aún capacitado para ver» ${ }^{111}$.

A nivel intelectual los resultados positivos de la lectura de los neoplatónicos no pueden ser más positivos. El P. Victorino Capánaga los resume así: «Con el método de la filosofía platónica descubrió San Agustín tres importan-

110. ID., o.c., $7,12,18$.

111. ID., o.c., $7,10,16$. 
tes cosas: las verdades eternas, las normas axiológicas de todo lo verdadero, lo bello y lo santo; la incorporeidad del espíritu humano, en que residen, como asiento inmediato; una Verdad ontológica, absoluta y fontal, última instancia de nuestros conocimientos y juicios de valor» ${ }^{112}$. La filosofía neoplatónica ofrece a Agustín los medios necesarios para purificar su mente de tantas y tantas incorrecciones que le impedían avanzar en el camino hacia la Verdad. A nivel intelectual nada o muy poco queda ya por hacer.

Ahora el quiebro en el camino es importante. Y, para ello, Agustín necesita algo nuevo. Algo que no ha encontrado en los neoplatónicos. Agustín necesita ahora la cura del corazón, limpiarse de la soberbia intelectual que aún le domina. «El egoísmo, en su doble forma de sensualidad y de orgullo, era el peso muerto con que braceaba su espíritu para levantarse del estado de abyección en que gemía». ${ }^{113}$. Agustín va a alcanzar esta meta en una segunda lectura de las Sagradas Escrituras, que esta vez sí que va a producir resultados positivos. De la mano de Pablo, el otro gran convertido, Agustín se va a encontrar, como no lo ha hecho hasta ahora, con la persona de Jesús. De un Jesús que se ha hecho camino, verdad y vida. La gracia del Mediador, desde la perspectiva de la kénosis, aceptada y vivida por Jesús como camino de redención para el hombre, va a revolucionar interiormente a Agustín y va a hacer saltar el cerrojo carnal que aún le aprisiona. Agustín recuerda ese momento con gran satisfacción, aprovechándole para desgranar su experiencia en un ramillete oracional. "Así, pues, con toda avidez, cogí las Escrituras venerables de tu Espíritu, con preferencia al apóstol Pablo, y fueron desvaneciéndose todos aquellos problemas en que a veces me parecía descubrir contradicciones e incoherencias entre sus palabras y el testimonio de la Ley y de los profetas. Y apareció ante mis ojos la verdadera y única identidad de tus palabras castas, $\mathrm{y}$ aprendí a alegrarme con temblor...

Tú eres justo, Señor, mientras que nosotros hemos pecado, hemos practicado la maldad, nos hemos comportado con impiedad. Tu mano se ha hecho pesada sobre nosotros...

¿Qué hará el hombre en medio de su miseria? ¿Quién le liberará de este cuerpo mortal, sino tu gracia por medio de Jesucristo nuestro Señor, a quien tú engendraste coeterno contigo y creaste en el comienzo de tus caminos...?

En aquellas páginas (las de los neoplatónicos) nadie canta: ¿Es que mi alma no va a someterse a Dios? De él viene mi salvación. Él es mi Dios y mi salvación. Él es quien me acoge; no vacilaré jamás. Nadie escucha allí la voz invitadora: Venid a mí todos los que estáis cansados. Consideran poca cosa

13

112. CAPÁNAGA, V., Introducción general a las obras de San Agustín, BAC, Madrid 1946,

113. ID., o.c., 15. 
aprender de él, porque es manso y humilde de corazón. Tú escondiste estas cosas a los sabios y entendidos, y se las has revelado a la gente sencilla.

Una cosa es contemplar desde una cima frondosa la patria de la paz, sin hallar el camino que conduce a ella, tras vanas tentativas de ensayar atajos perdidos, expuestos a las asechanzas de los desertores guiados por su jefe, el león y el dragón, y otra cosa muy distinta es mantenerse en el camino que conduce a ella... ${ }^{114}$.

Este hallazgo feliz, traducido en un encuentro del todo especial con el Mediador, constituye el principio del fin. Agustín está ya a las puertas de dar el paso definitivo, arrojándose sin traumas en los brazos del Dios de las misericordias. Agustín lo recuerda agradecido y lo expresa en una oración enfervorizada: «Dios mío, haz que yo evoque estos momentos de mi vida para darte gracias y que reconozca tus misericordias para conmigo. Que mis huesos se empapen de tu amor y digan: Señor, ¿quién semejante a ti? Rompiste mis cadenas, te ofreceré un sacrificio de alabanza» ${ }^{115}$.

Tras una serie de acontecimientos, entre los que hay que recordar la entrevista con Simpliciano y la narración de Ponticiano, Agustín se halla en la cresta de la tormenta final. Dios le acosa ya por todas partes. No hay posibilidad de evadir su acoso amoroso. Agustín describe este momento cumbre de su vida con una maestría inigualable. Profundo conocedor del hombre, Agustín describe su última y definitiva tormenta con rasgos tan dramáticos que resulta casi imposible contener las lágrimas al leer la escena. "Yo caí derrumbado a los pies de una higuera. No recuerdo los detalles del cómo. Solté las riendas de mis lágrimas y se desbordaron los ríos de mis ojos, sacrificio que te es aceptable. Si no con estas palabras, sí con este sentido, te dije cosas como éstas: Y tú, Señor, ¿hasta cuándo? ¿Hasta cuándo, Señor, vas a estar eternamente enojado? No te acuerdes, Señor, de nuestras maldades pasadas. Al sentirme prisionero de ellas, daba voces lastimeras: ¿Hasta cuándo voy a seguir diciendo mañana, mañana? ¿Por qué no ahora mismo? ¿Por qué no poner fin ahora mismo a mis torpezas?» ${ }^{116}$.

En este estado de ánimo oye la voz misteriosa que le invita a tomar el libro, precisamente el libro de las epístolas de Pablo, y leer. Es éste un dato eminentemente providencial. Ello le permite encontrarse con la persona de Cristo, a la que Pablo había amado apasionadamente. De Pablo iba a heredar Agustín su amor apasionado a Cristo. El Apóstol y Agustín son dos personas gemelas que vibran con intensidad inaudita en el amor a Cristo. Oída la invitación a tomar el libro y leer, Agustín coge las epístolas de Pablo y se encuentra al azar

114. SAN Agustín, Conf. Lib. 7,21,27.

115. ID., o.c., $8,1,1$.

116. ID., o.c., $8,12,28$. 
con un párrafo que le invita a despojarse de sus desórdenes y a revestirse de Cristo. «Nada de comilonas y borracheras; nada de lujurias y desenfrenos; nada de rivalidades y envidias. Revestíos más bien del Señor Jesucristo y no os preocupéis de la carne para satisfacer sus concupiscencias» (Rom 13, 13-14).

El drama había terminado. La tormenta había pasado y ahora hay una bonanza absoluta. Agustín lo expresa con palabras inolvidables: «Al punto, nada más acabar la lectura de este pasaje, sentí como si una luz de seguridad se hubiera derramado en mi corazón, ahuyentando todas las tinieblas de mi corazón» ${ }^{117}$.

En este momento de placidez interior, Agustín tiene un recuerdo especial para su madre. Él es consciente que todo lo ocurrido ha tenido, después de Dios, un protagonista de excepción. Tal protagonista es su madre, que, con sus lágrimas y oraciones continuas, han forzado la mano misericordiosa del Señor en favor del hijo extraviado. Por ello, Agustín se apresura a comunicar lo sucedido a su madre. «Acto seguido nos dirigimos los dos hacia mi madre (Alipio y él). Se lo contamos todo. Se llena de alegría. Le contamos cómo había ocurrido todo: salta de gozo, celebra el triunfo, bendiciéndote a ti que eres poderoso para hacer más de lo que pedimos y comprendemos. Estaba viendo con sus propios ojos que le habías concedido más de lo que ella solía pedirte con sollozos y lágrimas piadosas» ${ }^{118}$. Agustín da testimonio público con estas palabras de que su conversión se ha debido principalmente a las lágrimas y oraciones de su madre. Si la generación natural concede a Mónica el título sugestivo de madre en relación a Agustín, ahora ese título queda sublimado desde la generación espiritual. Agustín lo dice con palabras inegualables y cargadas de gratitud. «No puedo pasar por alto los sentimientos que mi alma tiene ansias de manifestar. Se refieren a aquella sierva tuya que me alumbró en la carne para nacer a la luz temporal, y que me parió en el corazón para nacer a la luz eterna. No voy a hablar de sus cualidades, sino que voy a hacer un panegírico de tus dones en ella» ${ }^{119}$.

A lo largo de esta exposición se ha podido notar que Agustín se muestra como un orante consumado. Habla con Dios con una naturalidad que asombra. Incluso desconcierta su lenguaje a hombres como nosotros, que sentimos el drama de la ausencia de Dios. Sus Confesiones son un permanente coloquio o diálogo con Dios, a quien comunica las peripecias de su vida con una naturalidad asombrosa. Pone de manifiesto con ello la familiaridad que había alcanzado con Dios. Frecuentemente su espíritu se desencadena en torrentes de los más representativos sentimientos religiosos. La admiración, la alabanza, la

117. ID., o.c., $8,12,29$.

118. ID., o.c., $8,12,30$.

119. ID., o.c., $9,8,17$. 
gratitu , el amor, se hacen presentes cons antemente en sus plegaria Agustín sabe descubrir la presencia de io en todas las cosas. Si es verdad ue poten ia la interioridad como lugar rivilegiado ara el encuentro con el Se or, no por eso hay que ol idar que tamb én las criaturas e ternas le ayudan para subir hasta el creador. ste doble camino de a censión a Dios se halla presente en uno de lo pasajes más bellos no sólo de las onfesiones, sino incluso de la literatura universal. Me refiero al llamado é tasis de Ostia. ómo dejar de recordar aquí esa fa os oración en la que ustín se $r$ trata como un orante perfecto on ersábamos, pues, solos los dos ustín ónica, con ran dul ura. Olvidándonos de lo pasado y proyectándonos hacia las realidades que teníamos delante, buscábamos untos, en presencia de la verdad ue eres $\mathrm{t}$, cuál sería la vida eterna de los santos, que ni el o o vio, ni el oído oyó, ni lle ó al coraz $\mathrm{n}$ del hombre $\mathrm{Ab}$ amos con avidez la boca del corazón al elevado chorro de tu $f$ ente, de la fuente de la vida ue hay en ti para que, rociados por ella seg $n$ nuestra capacidad, pudi $r$ mos en cierto modo ima inarnos una realidad tan maravillosa

ecorrimos gradualmente todas las realidades corporales, incluyendo el cielo esde donde el sol, la luna y las estrellas manda sus este los sobre la tierra.

Se uimos ascendiendo a $\mathrm{n}$ más dentro de nuestro interior, pensando, hablan o y admirando tus obras. Y llegamos hasta nuestras mismas mentes, y se uimos nuestro avance remontándo as asta llegar la región de la bundancia inagotable, donde apacientas a srael eternamente en los asti ales de la verdad, allí donde la vida es la sabiduría por la cual s crean todas las cosas de aqu las presentes, las pasadas y las futuras, mie tras que ella no es creada or nadie, sino que hoy es co o ayer y como se sie pre Mej $\mathrm{r}$ di ho, en ella no hay un fue i un será, sino sólo un es, orque es eterna, ya que 1 que ha sido y lo que será no es eterno

ientras hablábamos y sus irá amos por ella, llegamos a tocarla un poito con todo el etu de nuestro corazón y sus irand de mos allí auti as las primicias de espíritu. retornamos al son do de nuestra boca, ue es donde tiene principio y fin la palabra

Al escuchar estas palabras y el mensaje que transmiten, uno se siente gran emente peque 1 coraz $n$ de gustín se retrata a $u$ con una inme sidad que d sborda y asombra. Agustín se ma ifiesta a través de un lenguaje fao $\mathrm{nt}_{\mathrm{f}} \mathrm{o}$ a wiløsorcomo un contem lativo onsumad $Y$ se ha maestirc $\mathrm{i}$ lnoa in $\mathrm{p}$, -

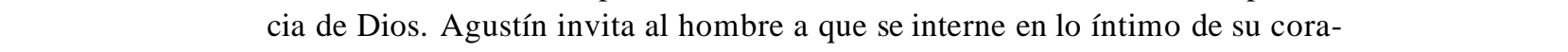


mino de la interioridad es ofrecido por Agustín a todo hombre. Y hay que re conocer que hoy ese camino reviste importancia peculiar. La dispersión y la alteración, que sufre el hombre de nuestros días, sólo pueden curarse con la vuelta a la interioridad. «Nos hallamos en el corazón del agustinismo. Elprin 
no avisado, nadie halla sino purificado. Dios, dejarte a Ti es ir a la muerte; seguirte a Ti es amar; verte es poseerte. Dios a quien nos despierta la fe, levanta la esperanza, une la caridad. Te invoco a Ti, Dios, por quien vencemos al enemigo, porque victoria tuya es que nosotros no perezcamos totalmente...

Ahora te amo a Ti sólo, a Ti sólo sigo y busco, a Ti sólo estoy dispuesto a servir, porque tú sólo justamente señoreas: quiero pertenecer a tu jurisdicción. Manda lo que quieras, pero sana mis oídos para oír tu voz; sana y abre mis ojos para que vea tus signos; destierra de mí toda ignorancia, para que te reconozca a $\mathrm{Ti} . . .{ }^{122}$.

Bastaría esta última muestra para poner de manifiesto que Agustín es un orante consumado. Un orante que sabe descubrir la presencia de Dios en toda la creación y, a su embrujo, se enciende en afectos de los más variados colores. Todo le ayuda a ver la magnitud del misterio divino, al tiempo que contempla su propia miseria. Este contraste, al igual que una cascada violenta, se precipita sobre el abismo de su nada. Y, desde aquí, desde su miseria e incapacidad para hacer el bien, surge la plegaria enfervorizada. Una plegaria en la que, de alguna manera, todo hombre de fe se siente embarcado, porque aquí Agustín se ha hecho intérprete del sentido religioso universal que configura al hombre. Sucede aquí como acontece en aquella otra frase también de carácter universal, puesta en los primeros compases de las Confesiones: «Nos has hecho para ti y nuestro corazón está inquieto hasta que descanse en ti» ${ }^{123}$.

Hemos escuchado al Agustín orante. ¡Ojalá nos hayamos contagiado de esa condición fundamental de su espíritu! ¿Qué, como él, nosotros seamos también hombres de oración, porque somos hombres de profunda fe! Sin fe no se puede seguir a Jesús. Y sin oración no es posible la fe en Jesús. Fe y oración se reclaman vitalmente. Quien no ora no debe preguntarse por la oración, sino por la fe. Una vez escuchado al Agustín orante, es preciso escuchar también al Agustín maestro de oración. Si digno de atención es lo primero, no lo es menos lo segundo. Lo que Agustín diga sobre la oración no será nunca resonancia de una palabra sin vida. Será siempre fiel reflejo de lo que él trató de vivir en fiel respuesta a la voluntad de Dios.

\section{AgUSTÍN MAESTRO DE ORACIÓN}

He presentado a Agustín desde la faceta de orante. En el cuadro, rico en figura y matices, aparecen trazos de todos los estilos de oración. Agustín es un orante perfecto desde cualquier ángulo de visión que se le contemple. Si hubie-

122. San Agustin, Solil. Lib. 1,2,3,5.

123. ID., Conf. Lib. 1,1,1. 
ra algo que resaltar, habría que decir que Agustín sobresale en el aspecto contemplativo de la oración. Queda siempre como ensimismado, asombrado en y ante la grandeza inabarcable de Dios. Agustín ha desarrollado como nadie el aspecto contemplativo del neoplatonismo. $Y$ lo ha hecho en cristiano: sin perder su identidad y perdiéndose en Dios. De ahí que no extrañan nada esos vuelos de águila caudal, a través de los cuales Agustín, trascendiendo las cosas creadas, ha sido capaz de fijar sus ojos en la luz deslumbrante de Dios.

Cuando Agustín habla de oración, cuando se le puede considerar como maestro de oración, no aparece casi nada de los antes afirmado. Agustín habla de la oración fundamentalmente desde la perspectiva bíblica. Y esta perspectiva adquiere su densidad más completa desde el punto de vista de la impetración. Para Agustín la oración es antes que nada impetratoria. «Si san Agustín identificaba la oración con la oración impetratoria, y si se nota su influencia en la teología posterior a él, nos es conveniente considerar brevemente lo que los autores contemporáneos piensan de la oración de súplica» ${ }^{124}$.

En la Biblia, carta dirigida por Dios a los hombres, Agustín se encuentra con la gran enseñanza del Señor acerca de la oración. Jesús, solicitado por un discípulo a que les enseñe a orar, contesta con esa sorprendente oración, resumen y síntesis de todo lo que se puede y debe pedir a Dios. Y para que no falte nada a la magnitud y belleza del cuadro, Jesús inicia su gran lección sobre la oración con la palabra «Padre». «Padre, santificado sea tu nombre, venga tu Reino, danos cada día nuestro pan cotidiano y perdónanos nuestros pecados, porque también nosotros perdonamos a todo el que nos debe, y no nos dejes caer en tentación». (Lc 11,2b-3). Para confirmar la esperanza de ser escuchados, al tiempo que se nos invita a hacer oración, Jesús narra la parábola del amigo. La insistencia en la petición alcanza lo que había sido desoído en un principio. Todo esto culmina con la gran lección: «Pedid y se os dará; buscad y hallaréis; llamad y se os abrirá. Porque todo el que pide, recibe; y el que busca, halla; y al que llama, se le abrirá» (Lc 11, 9-10).

Precisamente por esto, porque todo don perfecto desciende del Padre de las luces (cf. Sat 1,17), Agustín da un valor único al tema de la oración. «Recuerdo que me pediste, dice a Proba, y yo convine en ello, que había de escribir algo acerca de la oración. Ahora que ese Dios, a quien oramos, me ayuda y tengo tiempo y oportunidad, voy a pagar mi deuda y ponerme al servicio de tu piadoso deseo en la caridad de Cristo. No puedo explicar con palabras el gozo que me causó tu petición, pues en ella reconocí lo mucho que te preocupas por tan alto negocio...

124. García Montaño, G., Doctrina agustiniana de la oración. Augustinus, XVIII, 72-73, 279. 
Quien te infundió ese pensamiento, hace contigo, sin duda, lo que hizo con sus discípulos. Entristecidos quedaron, no por sí mismos, sino por el género humano, y desesperanzados de la salvación de todos, al oír que era más fácil que un camello entrara por el ojo de una aguja que un rico en el reino de los cielos. El Señor les hizo una portentosa y benigna promesa: que para Dios era fácil lo que para los hombres era imposible» ${ }^{125}$.

Un tema, aparentemente tan poco complicado como es la oraciónplegaria, brinda a Agustín la oportunidad de hacer reflexiones teológicas profundas. El punto de partida lo encuentra Agustín en la misma creación. Para el Pastor de Hipona la creación no termina con el acto de crear. Crear supone, por eso mismo, la determinación de un plan concreto, a fin de que las criaturas alcancen el fin de la creación y su propia felicidad. Si a esto añadimos que el hombre, por ser libre puede ser infiel al fin para que ha sido creado en base al pecado, entonces las cosas adquieren una nueva fisonomía. La providencia, tanto general como particular, tiene en este caso un carácter salvífico. La alternativa, por tanto, se presenta así: o Dios deja al hombre sumido en el pecado o se acerca a él para salvarlo. Dios opta por esta última alternativa. Al hombre herido por el pecado Dios le responde con la oferta de salvación, llevada a cabo en la obra y la palabra de su Hijo hecho hombre.

Creación y redención, dos actos de una única historia de salvación, sitúan la realidad humana en un plano de cercanía particular con lo divino, con Dios. Tal cercanía se configura de una forma muy concreta y muy peculiar en la plegaria. Por la plegaria el hombre reconoce que todo lo que es y todo lo que tiene no encuentra origen más que en Dios. Este reconocimiento descubre al mismo tiempo que su origen y su vida, desde cualquier ángulo de vista que se mire, están marcados por un amor no desmentido de Dios. De este modo, el amor se presenta como el verdadero artífice tanto de la creación como de la redención. «El dominio de Dios sobre el hombre es paterno, porque la creación es obra de su amor infinito. En el pensamiento de san Agustín ese amor es indefectible y cuida de las criaturas perpetuando la creación con su providencia: una providencia general, que mantiene en el ser toda la creación, y una providencia especial que guía al hombre a un fin superior. La oración es también el reconocimiento por parte del hombre de esta relación divino-humana, y, por tanto, observa san Agustín, no se debe nadie extrañar que quienes nieguen la Providencia nieguen también la oración» ${ }^{126}$.

El amor da un colorido especial a todo lo que cae bajo su influjo. Ello acontece de manera particular, cuando se trata de temas tan delicados como

125. San Agustin, Carta 130, 1,1. BAC, Madrid 1953, Tom. XI, 53. 241.

126. García Montaño, G., La eficacia de la oración impetratoria. Augustinus, XI, 42-43, 
son providencia y oración. A primera vista parecen dos cosas bastante incompatibles. ¿Para qué orar, si Dios cuida de nosotros y todo está ya determinado de antemano? ¿Es que se intenta cambiar sus designios, designios por otra parte, amorosos, con la oración? ¿No es esto en el menor de los supuestos un verdadero desatino? ¿No es mucho mejor no interferir en los planes de Dios? Todos estos interrogantes, y otros que pueden formularse sobre el tema, encuentran una respuesta por lo menos con cierta coherencia, cuando se sitúan en un marco de amor. Quien ora lo hace en la convicción de que es amado por Aquél que le invita a la oración. La oración hace sentir con una intensidad difílmente calculable que Dios es, ante todo, amor. En la oración es donde mejor se experimenta el amor de Dios y en donde con más seguridad se crece en amor de Dios. Para el orante auténtico resulta sumamente fácil ponerse en las manos de Dios, que todo lo dispone para el bien de los que le aman. «Por lo demás, sabemos que en todas las cosas interviene Dios para bien de los que le aman, de aquellos que han sido llamados según su designio» (Rom 8,28).

El orante, que contempla la creación y la redención desde una perspectiva de amor, tiene claro que Dios, el Padre de nuestro Señor Jesucristo y su propio Padre, no puede desentenderse ni de su vida ni de sus cosas. Es un Dios providente. Un Dios cercano. Un Dios en el que existe, se mueve y vive. Un Dios que ha venido a poner su morada en el centro de su corazón. Lo siente y lo palpa como realidad amiga y como plenitud de su ser. Ninguna realidad es más humanizante que la presencia de Dios. Y en ninguna realidad esta presencia es tan viva como en la oración. De ahí que la oración auténtica conduzca sin traumatismos al humanismo más pleno. «Él oye nuestros gemidos, dice Agustín, ve nuestros suspiros, intuye nuestros deseos y gustosamente acepta nuestra petición» ${ }^{127}$. "Toda mi esperanza no estriba sino en tu muy grande misericordia. Da lo que mandas y manda lo que quieras» ${ }^{128}$.

Creo que la oración, que parte de la creación y de la redención como obras del amor de Dios, es el mejor medio para descubrir la realidad salvífica de Dios y la verdad del hombre. A la luz de Dios, en estrecha colaboración con su propia luz, el hombre supera siempre la tentación prometeica, hoy, sobre todo, tan en boga tras las peroratas filosóficas de Nietzsche. Reconoce en la fe que lo más correcto y objetivamente exacto es mantenerse en su puesto y no ver a Dios como émulo activo de su desarrollo personal y de su progreso técnico. Lo cual conlleva confesar sin traumas de empobrecimiento que todo lo que es y todo lo que tiene es don de Dios. En contraste con su pequeñez, el hombre descubre también en la oración la grandeza de Dios. Una grandeza, por cierto, que no abruma. Al contrario, una grandeza que se ha despojado de

127. San Agustín, En. in Ps. 26,23; PL 36, 211

128. ID., Conf. Lib. 10,24,40. 
su esplendor para hacerse cercana a la pequeñez del hombre en la encarnación del Hijo de Dios. Dios se ha situado tan en la orilla del hombre que prácticamente ha suprimido todas las distancias. Sólo resta que el hombre no se entontezca con vanos pensamientos, se encierre en sí mismo y se incapacite así para el diálogo con Dios.

Situado el tema de la oración en el marco del amor, Agustín se plantea una serie de cuestiones, a las que, ayudado del mensaje bíblico, va a tratar de dar respuesta. La respuesta a tales cuestiones sintetiza la doctrina de Agustín sobre la oración. Para seguir una cierta metodología, voy a dividir dicha enseñanza en algunos apartados.

\section{a) La oración como tarea ininterrumpida}

Agustín se siente impresionado por la frase de Pablo: «Orad constantemente» $(1$ Tes 5,17$)$. Creo que todos los cristianos nos sentimos también impresionados y hasta, si se quiere, desconcertados ante la consigna del Apóstol. Y las preguntas se suceden en cascada: ¿Cómo es posible orar constantemente? ¿No está Pablo en la luna cuando escribe esa frase? ¿Acaso no tiene el hombre que atender a una serie de cosas, sin las cuales no podría vivir? ¿Cómo se puede compaginar la oración constante, y la atención a las necesidades primarias de la vida? O Pablo no habla en serio y entonces no se entiende para qué escribe tal consigna, o, si lo hace, queda muy difícil llevar a cabo tal consigna. El mensaje de Pablo produjo una inquietud profunda en aquel hombre que se llama a sí mismo «el peregrino ruso». Oigamos sus palabras: «El domingo 24 después de Pentecostés fui a rezar a la iglesia. Durante la misa se leía la primera epístola de S. Pablo a los tesalonicenses, donde dice entre otras cosas: 'orad sin interrupción' (1 Tes 5,17). Este versículo se imprimió en mi memoria y me puse a pensar cómo es posible rezar sin interrupción, ya que el hombre tiene que ocuparse de tantas cosas para ganarse la vida. Consulté la Biblia y leí con mis propios ojos las palabras que había oído, es decir, que siempre, en todo tiempo, en todo lugar, debemos orar levantando las manos (Ef 6,18; 1 Tim 2,8). Reflexioné mucho, mas no puede convencerme.

¿Qué debo hacer? me preguntaba. ¿Dónde encontraré quién me lo explique? Visitaré todas aquellas iglesias que cuentan con famosos predicadores; quizá oiré algo que pueda iluminarme. Y así lo hice. Escuché varios sermones, excelentes, sobre la oración; qué es la oración, cuán necesaria es, cuáles son sus frutos...; pero ninguno enseñaba cómo es posible orar incesantemente. Escuché un sermón sobre la oración continua e ininterrumpida, pero sin señalar los medios para llegar a ella. No obteniendo lo que deseaba, dejé de asistir a los sermones públicos. Elegí otro camino: encontrar, con la ayuda de Dios, un 
hombre experimentado y sabio que pudiera enseñarme personalmente aquello que tan violentamente atraía mi alma» ${ }^{129}$.

Llama la atención la enorme ingenuidad con que se plantea la cuestión de la oración constante el personaje que se esconde bajo la denominación del peregrino ruso. $Y$, sobre todo, uno se siente admirado, casi desconcertado, ante la preocupación de un mensaje, que, a primera vista, no parece ser más que una hipérbole imposible de llevar a la práctica. Lo cierto es que el tal peregrino ruso encontró, tras no deleznables peripecias, a un maestro, a un staretz, que, usando de un método tan sencillo como es el método de la repetición de una oración-jaculatoria, le condujo a la práctica de una oración continua.

La solución dada por el staretz a las inquietudes del peregrino ruso no sólo asusta, sino que aparece desafortunada. No parece ser ése el mensaje contenido en la frase paulina. Al peregrino le servió. Pero hay que reconocer que el camino seguido no es ni mucho menos afortunado. Tal forma de oración conduciría al hombre a una total despreocupación de los compromisos con la tierra. El hombre ni puede normalmente ni debe aspirar a una espiritualidad tan deshumanizada. La solución del peregrino ruso puede servir para alguna persona muy concreta. Pero es inviable para el común de los creyentes. Si la aceptáramos, habría que concluir que la oración sería un tema reservado a algunos iniciados. Lo cual supondría apartarse de la enseñanza bíblica. Según esta enseñanza la oración es algo consustancial a la vivencia del cristiano. Sin oración es imposible vivir la fe. $\mathrm{Y}$ sin fe es imposible ser cristiano. Con ello no se quiere hacer un juicio descalificativo del mensaje del peregrino ruso. Tan sólo se quiere matizar su solución al tema de la oración continua.

Agustín se plantea el mismo problema que el peregrino ruso. Su respuesta es mucho más sencilla, mucho más humana y, por tanto, perfectamente asequible para el creyente. Al oír la frase de Pablo: 'orad sin interrupción', Agustín se pregunta: «¿Qué significa eso sino 'desead sin interrupción' la vida bienaventurada, que es la eterna, y que os ha de venir del favor del único que os la puede dar? Deseémosla, pues, siempre de parte de nuestro Señor y oraremos siempre. Pero a ciertas horas substraemos la atención a las preocupaciones y negocios, que nos entibian en cierto modo el deseo, y nos entregamos al negocio de orar; y nos excitamos con las mismas palabras de la oración a atender mejor al bien que deseamos, no sea que lo que comenzó a entibiarse se enfríe del todo y se extinga por no renovar el fervor con frecuencia» ${ }^{130}$. Agustín se hace eco de este pensamiento en múltiples ocasiones. «Tu deseo es tu oración; si el deseo es continuo, continua es también tu oración» ${ }^{131}$.

129. StranNiK, El peregrino ruso, Ed. de Espiritualidad, Madrid 1984, 43-44.

130. San Agustín, Carta 130, 9,18.

131. ID., En. in Ps. 37, 13-14. CCL 38, 391-392. 
Agustín nos presenta una solución al problema planteado por las palabras de Pablo muy acorde con nuestra condición humana. Todos podemos desear orar sin interrupción, aunque en momentos concretos tengamos que hacer cosas que no se parecen en nada a lo que se llama oración. Este deseo, vivo y permanente, es como el aceite que hace posible mantener ardiente la llama de la oración. Con lo cual ni se descalifica ni se minusvalora los tiempos dedicados al ejercicio de la oración. Agustín habla de esos tiempos y los presenta como algo absolutamente necesario. Sin esos tiempos dedicados al ejercicio de la oración, el deseo de la misma termina por ajarse y morir. «Siendo esto así, no será inútil o vituperable el vacar largamente a la oración, a saber, cuando otras ocupaciones y actividades buenas y necesarias no nos lo impidan, aunque también en ellas, como he dicho, hemos de orar siempre con el deseo. Porque no es lo mismo orar con locuacidad que orar durante largo espacio, como algunos piensan. En efecto, del mismo Señor está escrito que pernoctaba en oración y que oró prolijamente. ¿No era darnos ejemplo, orando con oportunidad en el tiempo, aunque con el Padre oye en la eternidad?» ${ }^{131 b}$. Es, pues, necesario compaginar tiempos fuertes de oración con otras actividades, que, a primera vista, no tengan una fisonomía típicamente oracional. Para Agustín el hilo, que hace posible la relación profunda entre oración y vida, es precisamente el deseo. Quien desea orar siempre, cumple la consigna de Pablo: «orad sin interrupción» $(1$ Tes 5,17$)$. Y la de Lucas: «Es precisó orar siempre y no desfallecer» $(18,1)$.

Si el deseo es la respuesta de Agustín al problema planteado por la oración sin interrupción, también se puede afirmar que el deseo define según Agustín, a la misma oración. «Tu deseo es tu oración; si el deseo es continuo, continua es también la oración. No en vano dijo el Apóstol: 'orad sin cesar'. ¿Acaso sin cesar nos arrodillamos, nos prosternamos, elevamos nuestras manos, para que se pueda afirmar: 'orad sin cesar'? Pero existe otra oración interior y continua, que es el deseo. Cualquier cosa que hagas, si deseas aquel reposo sabático, no interrumpas la oración. Si no quieres dejar de orar, no interrumpas el deseo.

Tu deseo continuo es tu voz, es decir, tu oración continua» ${ }^{132}$. Muy concisamente afirma en otro lugar: «El deseo ora siempre, aunque calle la lengua. Si siempre deseas, siempre oras» ${ }^{133}$.

131b. ID., Carta 130, 10,19.

132. ID., En. in Ps. 37, 13-14.

133. ID., Serm. 80,7. 


\section{b) Qué pedir}

Agustín trata muchas veces del objeto de la oración. El tema le preocupa de manera particular. Y, aunque parezca extraño, tiene motivos para ello. Agustín es un hombre creyente que, desde cierta óptica se presenta como radical como absolutista. Da la impresión, al menos en ciertos casos, de no preocuparse suficientemente por las cosas de este mundo. Por ello, Agustín encaja muy difícilmente en el marco de una espiritualidad de las realidades terrenas, que es precisamente una de las formas espirituales más presentes en nuestro tiempo. Esta espiritualidad está marcada por la autonomía de lo terreno. Una autonomía, no ciertamente absoluta, pero sí lo suficientemente amplia, como para dar densidad propia a las cosas de este mundo. El concilio habla de esta autonomía en términos muy claros. Y si lo hace es porque tal autonomía no estaba reconocida incluso a nivel eclesial. «Si por autonomía de la realidad terrena se quiere decir que las cosas creadas y la sociedad misma gozan de propias leyes y valores, que el hombre ha de descubrir, emplear y ordenar paulatinamente, es absolutamente legítima esta exigencia de autonomía» ${ }^{134}$.

El reconocimiento óficial de la autonomía de lo terreno ha supuesto un cambio radical en la valoración de lo trascendente y en la forma de contemplarlo en relación con los valores terrenos. Antes, digamos en el cristianismo de acuñación sacral, la preocupación fundamental era «afirmar la primacía de la dimensión religiosa de la existencia, como reflejo de la primacía y de la trascendencia de Dios. La secularización no es captada más que como fenómeno negativo ('horizontalismo', 'naturalismo', 'mundanización'), un peligro del que hay que defenderse y que en última instancia no es fácil distinguir del ateísmo (y quizá esto no por falta de coherencia, de valor de sus consecuencias). Por lo mismo, la actitud global de cara al mundo moderno no puede ser más que de crítica y de defensa. Esta postura halla su expresión más pura en el Syllabus. La primacía de lo religioso implica que todo le esté subordinado, que encuentre en lo religioso su fundamento y su justificación; que lo religioso constituya el principio de la unidad de la vida, que no se pueda de ninguna forma comportarse a un nivel profano, como si Dios no existiera.

El compromiso profano sólo puede encontrar una justificación válida en Dios, como última instancia. Dicho en otros términos: no existe una moral laica, puesto que, si bien el ateo tiene una conciencia y una vida morales, es incapaz, sin embargo, de darles fundamento, de justificar el carácter absoluto que le vincula a una obligación. No hay humanismo sin Dios» ${ }^{135}$.

134. VATICANO II, GS. 36b.

135. GiraRdi, J., Cristianismo y liberación del hombre, Sígueme, Salamanca 1973, 22-23. 
Tras muchos años, incluso siglos, de cristianismo sacral aparece lo que muy bien se puede llamar el cristianismo secularizado. La sola presencia de estos dos términos, tan profundamente unidos como aquí sucede, resulta un tanto extraño. No parece muy afortunada la expresión cristianismo secularizado. $\mathrm{Y}$, sin embargo, hay que reconocer la legitimidad de esa expresión. Este cristianismo es fruto de un movimiento cultural que se desarrolla extramuros de la Iglesia, afectando a toda su realidad religioso-vivencial de manera profunda. Dicho movimiento ha servido a la Iglesia como instrumento purificador. J. Girardi retrata así al cristianismo secularizado: «Para nosotros, el 'cristianismo secularizado' no se reduce a las dimensiones seculares, sino que las asume en su autonomía propia, esto es, en su valor y en su dinamismo propios, aceptando los cuestionamientos y las transformaciones que esto implica en la manera de pensar en Dios y en su presencia. No es que se ponga entre paréntesis la subordinación del hombre a Dios, sino tan sólo critica una forma instrumental de concebirla. Entendida de esta forma, la secularización se convierte en el presupuesto necesario para redescubrir el lugar de la originalidad cristiana y el sentimiento de dependencia radicales que ella implica.

Creemos poder sintetizar este modo de cristianismo en unas cuantas tesis centrales:

Primera tesis: Todo valor humano personal y comunitario puede y debe ser asumido por sí mismo por el cristiano y según todas sus implicaciones...

Segunda tesis: Esta exigencia puede y debe convertirse en un criterio parcial del valor y de la verdad de la religión y al mismo tiempo proporcionar a la lectura bíblica una nueva clave hermenéutica...

Tercera tesis: Si los valores humanos, personales y comunitarios, son considerados como medios o consecuencias de los valores religiosos, si su autonomía no es reconocida, serán inevitablemente sacrificados. Por necesidad, tarde o temprano, habrá una mutilación del hombre. La religión será entonces, en cierta medida, una alienación...

Cuarta tesis: La religión de una persona o de una comunidad, humanamente mutiladas, estará viciada en su dinamismo propio; por el contrario, una humanidad plenamente desarrollada estará más preparada para una religión auténtica» ${ }^{136}$.

Se ha hecho un retrato, aunque sea un poco robotizado, del cristianismo sacral y del cristianismo secularizado. El cristianismo de corte sacral ha sido la forma concreta de encarnar el cristianismo a lo largo de varios siglos. Como forma, ha tenido sus limitaciones e, incluso, sus equivocaciones. Exacerbó la inquietud por las cosas del más allá y auspició una ascética de huída y despre-

136. ID., o.c., 27-40. 
cio del mundo. Alimentó de manera excesiva lo sacral como lugar del encuentro con Dios. Las bendiciones y las consagraciones de cosas y lugares se multiplicaron de forma casi escandalosa hasta dar la impresión de que sólo así se conseguía y además de forma mágica la protección de Dios. La mentalidad pagana, esencialmente sacral, logró filtrarse en el mensaje encarnado del cristianismo, de tal forma que lo desfiguró en parte. De ahí que la mentalidad secularizada ha servido de instrumento purificador, a la hora de superar el cristianismo sacralizado. De entrada, hay que reconocer que es una mentalidad más acorde con el mensaje cristiano. El hecho de aceptar la creación concede a las cosas creadas una densidad propia, unos valores distintos de los divinos aunque, es verdad, mantiene esa dependencia absoluta de todo frente a Dios. Al mismo tiempo, el cristianismo nada tiene que sacralizar, pues confiesa una verdadera dependencia de todo frente a Dios basada en el hecho de la creación. Toda la realidad está como invadida de Dios y, sin esta referencia a Dios, se desvanece. «Si autonomía de lo temporal quiere decir que la realidad creada es independiente de Dios, y que los hombres pueden usarla sin referencia al Creador, no hay creyente alguno a quien se le escape la falsedad envuelta en tales palabras» ${ }^{137}$.

La secularización bien formulada es el marco en que se mueve la cultura de nuestro tiempo. Por eso, hay que decir que la forma de encarnar nuestro cristianismo debe estar acorde con ella. Sin mimetismos y sin exageraciones. Ello, por lo demás, responde a lo típicamente cristiano. Lo cual no autoriza al hombre para que se constituya en centro de nada ni de nadie. Esta realidad le corresponde sólo y exclusivamente a Dios. El hombre nunca puede ser de suyo un valor absoluto. El Absoluto sólo es Dios. Reconociéndolo, el hombre ni se agranda ni se achica. Se mantiene en su puesto. Con lo que guarda su dignidad auténtica.

Llegados aquí, surge con fuerza una pregunta: ¿En qué modelo de cristianismo se mueven la vida y el pensamiento de Agustín? Esta pregunta no es inútil. Su respuesta nos va a ofrecer la clave para entender qué es lo que Agustín dice acerca de lo que se debe pedir en la oración. Naturalmente que la respuesta no se debe tomar en ningún caso cơmo una respuesta simplista. El problema es muy complicado. Y la respuesta, por tanto, será siempre limitada y se referirá tan sólo a líneas claves del problema.

Según esto, se puede decir que Agustín vive un cristianismo sacralizado. Esta forma de encarnar el cristianismo marca su pensamiento, que es casi lo mismo que afirmar que marca el pensamiento espiritual de Occidente, debido a la enorme influencia de Agustín. «En la mentalidad de cristiandad y en la

137. VATICANO II, GS. 36c. 
perspectiva que la prolonga, las realidades terrenas carecen de autonomía propia. Lo temporal no tiene una auténtica consistencia frente a la Iglesia. Ésta, en consecuenica, lo utiliza para sus propios fines. Son las secuelas de lo que se llamó el 'agustinismo político'. El proyecto por el reino de Dios no deja lugar a un proyecto histórico profano» ${ }^{138}$. Es normal que, en esta perspectiva, las realidades terrenas, digamos lo que hoy se esconde tras el vocablo mundo, no tengan mayor eco. Aquí interesa antes que nada lo que tiene específico peso de eternidad. Algo de esta mentalidad se deja escapar en este apasionado diálogo que mantienen Agustín y la razón. Dice Agustín: «He rogado a Dios. ¿Qué quieres, pues, saber?, le pregunta la razón. Todo lo que he pedido, le responde Agustín. Será mejor que lo resumas brevemente, le dice la razón. Quiero conocer a Dios y al alma; añade Agustín. ¿Nada más?, increpa la razón. Nada más responde lacónicamente Agustín" ${ }^{139}$. Como se ve, Agustín no siente mayor inquietud, antes bien parece marginar el tema, por el mundo. Para Agustín la vía espiritual es por antonomasia la vía interior. Agustín, en verdad, no considera al mundo, lo material, como algo malo. En sus Retractaciones reprueba una frase suya que afirma que amar al cuerpo es enajenarse ${ }^{140}$. Con todo, hay que reconocer que Agustín ve más peligros que vẹntajas en todo lo que se esconde tras el término materia o mundo, a los que, fruto de su mundo sacral, los ve siempre en función de los bienes del espíritu.

Con esto por delante, tenemos ya la clave para anticipar, primero, y confirmar, después, qué es lo que Agustín considera fundamentalmente objeto de petición. Por lo demás, él no se recata en este sentido. Es claro de forma incontestable. Hablando con Proba, en la preciosa carta que le dirige precisamente sobre el tema de la oración, le dice: «Puedo decírtelo en dos palabras: pide la vida bienaventurada.

Todos los hombres quieren poseerla, pues aún los que viven pésima y airadamente no vivirían de ese modo, si no creyesen que así son o pueden ser felices. ¿Qué otra cosa has de pedir, pues, sino la que buscan los buenos y los malos, pero a la cual no llegan sino sólo los buenos?» ${ }^{141}$.

Agustín responde de forma muy clara a la inquietante pregunta sobre lo que se puede y debe pedir. Y su respuesta muy concisa queda formulada en estas dos palabras: la vida bienaventurada. Una expresión en apariencia sencilla, pero llena de matices que la inteligencia privilegiada de Agustín va desmenuzando. Él mismo plantea la cuestión adelantándose a una hipotética pregunta de Proba, a quien está hablando. «Quizá me preguntes aquí qué es la vi-

138. Gutiérrez, G., Teología de la liberación, Sígueme, Salamanca 1972, 83-84.

139. SAN AGuStín, Solil. $2,7$.

140. ID., Cf. Retract. 2,15,2.

141. ID., Carta 130, 4,7. 
65

AGUSTÍN D L $\quad Y$ AESTRO D ORACIÓN

197

$$
{ }_{\mathrm{g}}{ }^{142} \cdot \mathrm{u}
$$

d

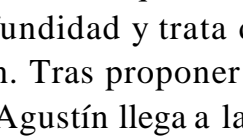

n jo

N

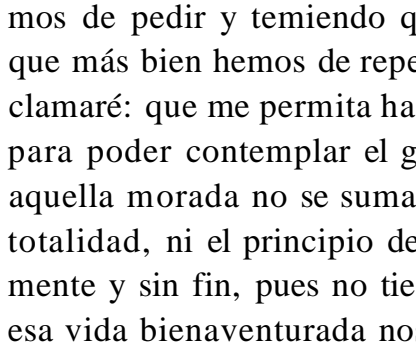

a

h

a
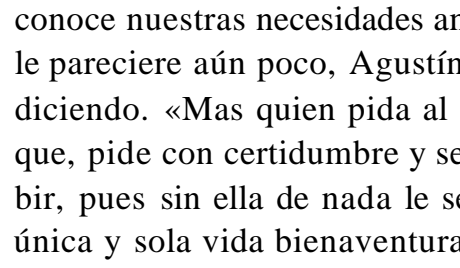

, E

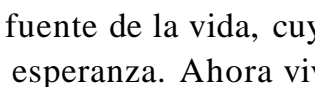

$\mathrm{u}$

$\begin{array}{ll}\text { b } & \text { d } \\ \text { m s g } & \text { es } \\ \text { Ah } & \end{array}$

1

st

S

ú

$\mathrm{x}$

$\tilde{\mathbf{n}}$

- c

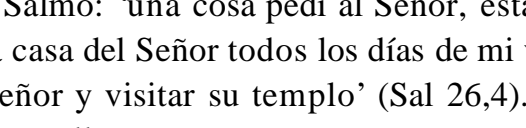

$\mathrm{u} t$

$\mathrm{T}$

v

$\mathrm{P}_{\mathrm{V}}^{\mathrm{Z}}$

$\begin{array}{ccc} & \mathrm{j} \\ \mathrm{X} \quad{ }^{143} . \mathrm{C}\end{array}$

ú

h

$\mathrm{t}$

y
S

á

m

a

b

z Y

é

á

m

bi

u

$\mathrm{y}$

$\mathrm{t}$

D

h

42.

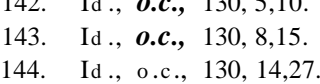


gunda perspectiva, interpela a todos los creyentes con palabras intensamente persuasivas. «Deja todos los amores. Más hermoso es aquel que hizo todas las cosas, el cielo y la tierra. Sea nuestra esperanza nuestro Dios. Quien lo hizo todo, es mejor que todo; quien hịo las cosas pulcras, es más hermoso que ellas; quien las cosas fuertes, es más fuerte que ellas; quien hizo las cosas grandes, es más grande que ellas: en cualquier cosa que ames, puedes encontrarle a él. Aprende a amar en la criatura al Creador, en las cosas hechas al que las hizo. No te retengas en nada de lo que Él ha hecho y pierdas a Aquél por el que tú mismo has sido hecho. Luego, es bienaventurado el varón cuya esperanza es el nombre del Señor, y no ha puesto su mirada en las vanidades ni en las mentiras insensatas» ${ }^{145}$. Usando el tono exhortativo y dándole un aire de urgencia insoslayable se dirige a cada uno de sus posibles oyentes: «Sea el Señor tu Dios tu esperanza, no esperes otra cosa de tu Señor, sino que el mismo Señor tuyo sea tu esperanza. Pues muchos esperan de Dios dinero, otros muchos, honores caducos y perecederos; por cierto, cualquier otra cosa fuera del mismo Dios. Pero tú solicita al mismo Dios tuyo; más aún, despreciadas todas las demás cosas, corre hacia él: olvidándote de todo, acuérdate de él; dejando atrás otras cosas, tiende hacia él. Él mismo ciertamente corrige al extraviado, conduce hacia sí y guía al recto; sea, pues, él mismo tu esperanza, el que te guía hacia sí $\mathrm{y}$ te conduce» ${ }^{146}$.

Agustín es un creyente coherente. Lo que aconseja a los demás, lo ha puesto él primero en práctica. Del predicador, y él lo fue en grado sumo, había dicho que sea orante antes que predicador. Y esto lo cumplió él con fidelidad exquisita. Por eso, no nos debe extrañar, sorprendería lo contrario, que él pida para sí lo que aconseja pedir a los demás. «Mirando siempre con la vista fija en la regla de la fe, con tu auxilio, Dios mío, busqué lo mejor que pude. $Y$ deseé comprender mis creencias, discutí y me fatigué mucho. ¡Oh Señor!, mi única esperanza, óyeme, no permitas que la fatiga y el desaliento me impidan buscarte con ardor. Ya que tú me hiciste la gracia de encontrarte más y más, dame la fuerza de buscarte. Tú conoces mi fuerza y mi flaqueza; cura ésta y apoya aquélla. Delante de ti está mi ciencia y mi ignorancia; ábreme, cuando llamo, acógeme, cuando entro. Que yo me acuerde de ti, que te conozca y que te ame» ${ }^{147}$.

«Toda mi esperanza está depositada sólo en tu misericordia, que es inmensamente grande. Da lo que mandas y manda lo que quieras. Nos mandas guardar la continencia. Y dándome cuenta - dijo alguien-de que nadie puede ser continente, si Dios no se lo concede, una señal de sabiduría era ya saber

145. ID., En. in Ps. 39, 7-8.

146. ID., o.c., 39, 7-8.

147. ID., De Trin. 15,51. 
de quién procede este don. A través de la continencia nos viene el reajuste y la reconducción a aquella unidad desde donde nos precipitamos dispersándonos en multitud de afluentes. Te ama menos aquel que ama contigo alguna cosa que no ama por ti. ¡Oh amor, que siempre ardes y que nunca te apagas! Caridad, ¡Dios, mío, enciéndeme! Mandas la continencia, ¿no? Pues da lo que mandas y manda lo que quieras» ${ }^{148}$.

Agustín nos ha dicho qué es lo que debemos pedir. Y lo ha hecho con esa convicción de que hace gala siempre que se trata de algo importante y definitivo. Podemos decir que en esto Agustín no se anda por las ramas. Va derecho al meollo del tema. Para él todo lo que no tenga valor de eternidad resulta siempre secundario. Agustín no excluye como objeto de petición las cosas de este mundo. «Pidamos también estos bienes temporales, pero con moderación, con la seguridad de que, si los recibimos, los da quien sabe lo que nos conviene» ${ }^{149}$. Hablando del mismo tema dice en otro lugar: «Hay dos clases de bienes: los temporales y los eternos. Los temporales son: la salud, las riquezas, el honor, los amigos, la casa, los hijos, la esposa y las demás cosas de esta vida por la que peregrinamos. Situémonos en la mansión de esta vida como peregrinos de paso, no como propietarios que han de permanecer. En cambio, los bienes eternos son, ante todo, la misma vida eterna, la incorrupción y la inmortalidad de la carne y del alma, la compañia de los ángeles, la ciudad celeste, la dignidad indefectible, el Padre y la patria, él sin muerte, ella sin enemigos. Deseemos estos bienes con todo el ardor, pidámoslos con toda perseverancia, no con palabras largas, sino con el gemido como testigo. El deseo ora siempre, aunque calle la lengua. Si siempre deseas, siempre oras» ${ }^{150}$. Como se ve, Agustín se interesa poco por las cosas de este mundo. No las excluye de la oración, pero quedan siempre relegadas a un lugar muy secundario. Tal vez, excesivamente secundario. Aparte de la verdad que hay en ello, me parece que el fenómeno obedece a esa tendencia espiritualista de la que ya se ha hablado en este artículo. Agustín contempla todas las cosas en función de lo eterno. Por lo que el compromiso con las mismas será siempre un compromiso desvaído. La espiritualidad cristiana, al menos la occidental, de la que Agustín ha sido mentor privilegiado, ha estado marcada por la consigna de la huída más que por la consigna del compromiso. $Y$ en ello hay que reconocer un error no pequeño. Las realidades terrenas tienen su consistencia propia y pueden y deben ser objeto de oración y objeto de compromiso. La tierra no es simplemente posada de tránsito, sin casi densidad y contenido. En la tierra se comienza ya a construir el reino de Dios. Y esta tarea es impensable en una espirituali-

148. ID., Conf. Lib. $10,29,40$.

149. ID., Serm. 80,7.

150. ID., Serm. 80,7. 
dad de cuño absentista. Mejorar la tierra es hacer posible que el hombre sea más hombre, que el hombre viva de una forma cada vez más humana. Y esto entra con carácter prioritario en los planes salvíficos de Dios. «Todo esto se traduce en el abandono paulatino de expresiones como fin sobrenatural, vocación sobrenatural, orden sobrenatural y en el empleo cada vez más frecuente del término 'integral'...

La consecuencia más inmediata de esta perspectiva es que las fronteras entre vida de fe y tarea terrestre, iglesia y mundo, se hacen más fluidas...

Pero hay otra consecuencia que nos importa. Esta afirmación de la vocación única a la salvación, más allá de toda distinción, valoriza religiosamente, en forma totalmente nueva, el actuar del hombre en la historia: cristiano o no cristiano. La construcción de una sociedad justa tiene valor de aceptación del reino o, en términos que nos son más cercanos: participar en el proceso de liberación del hombre es ya, en cierto modo, obra salvadora»" ${ }^{151}$. A esta luz, las realidades terrenas adquieren dimensiones insólitas y un carácter salvífico que no siempre se les había reconocido. $\mathrm{Y}$, por ello, se hacen objeto de oración con una densidad nueva, que, en cierta medida, las eleva a categoría de eternidad. No son ni mucho menos tan secundarias como se las había considerado.

\section{c) Eficacia de la oración}

Nos encontramos ante un punto muy delicado. ¿Se alcanza lo que se pide? Este interrogante azota violentamente a gran parte de las personas que oran. Muchas de ellas palpan en su propia carne la ineficacia de la oración. «Dios no me escucha», se oye decir con relativa frecuencia. $Y$ en esa expresión se escucha muchas veces el eco de una no desmentida desilusión. Lo cual es signo evidente de que estamos ante un punto de gran importancia, que no se puede marginar sin más.

El tema de la eficacia de la oración ocupa parte importante de la doctrina agustiniana sobre la oración. Buen observador, Agustín toma nota del fenómeno de la ineficacia en términos muy realistas: "El Señor nos exhortó a pedir, buscar y llamar diciendo: 'Pedid, y recibiréis; buscad, y hallaréis; llamad, y se os abrirá'. La primera dificultad que suele oponerse consiste en que muchos piden y no reciben, buscan y no hallan, llaman y no les responde. ¿Cómo, pues, todo el que pide recibe?... ${ }^{152}$. En otro texto, también muy directo, afirma: «¿Por qué muchos piden y no reciben, si tenemos la promesa de que todo el que pide recibe?... Resulta que los malos piden y reciben, mientras que los buenos piden y no reciben...» ${ }^{153}$.

151. Gutiérrez, G., Teología de la liberación, Sígueme, Salamanca 1972, 107-108.

152. San Agustín, Wilm. 12,2 en 'Misc. Agost.' I, 706.

153. ID., Wilm. 12,3,en 'Misc. Agosto.' I, 706. 
A pesar de estas observaciones fundamentadas en hechos concretos, Agustín está plenamente convencido de la eficacia de la oración auténtica. Tal convencimiento se apoya en el mensaje bíblico. Las palabras del Señor al respecto son claras, clarísimas. Partiendo de ese convencimiento, Agustín se esfuerza en penetrar teológicamente en el tema. Es su consigna. «Cree, para entender». El primero acepta el mensaje y luego trata de penetrar con su mente lúcida en el mismo.

La oración auténtica es eficaz. De ello no duda Agustín. No puede dudar, pues significaría desconfiar de la palabra del Señor. El tema le brinda la oportunidad de construir todo un discurso teológico. Agustín nunca se anda por las ramas. Aborda todos los temas con un lujo de erudición teológica impresionante. Para Agustín el tema de la oración abarca un horizonte mucho más amplio de lo que, a primera vista, aparece. Se puede decir que, según la visión agustiniana, envuelve toda la obra de Dios con el hombre: desde la creación hasta la redención. $\mathrm{O}$, si se quiere mejor, creación y redención como dos actos de una sola historia: la historia de la salvación. Y ambos actos impulsados por el único movimiento que Dios puede realizar: el amor.

La creación es fruto más del amor que del poder de Dios. Dios no crea para alardear de un poder único, sino para comunicar su profundo ser, que es el amor. Este dato es de tal magnitud que marca, de una vez por todas, la relación de Dios con todas sus criaturas. Por ello, Dios no va a quedar ensimismado en sí mismo, contemplando y admirando de lejos su obra, sino que va a estar presente, asumiendo y viviendo, por así decirlo, todas las vicisitudes de su creación. Dios no es el dios dormilón de los mitos. Es el Dios activo y presente de la historia de la salvación. En el marco de esta cercanía, Dios se va a interesar particularmente por aquella criatura que hizo a su imagen y semejanza: el hombre. La creación va a tener su prolongación natural en la Providencia, que todo lo dispone para que el hombre alcance los fines por los que ha sido creado: la glorificación de Dios y su propia felicidad. «El dominio de Dios sobre el hombre es paterno, porque la creación es obra de su amor infinito. En el pensamiento de san Agustín ese amor es indefectible y cuida de las criaturas perpetuando la creación con su Providencia: una providencia general que mantiene en el ser toda la creación y una providencia especial que guía al hombre a un fin superior. La oración es también el reconocimiento por parte del hombre de esta relación divino-humana y, por tanto, -observa san Agustínno se debe nadie extrañar que quienes nieguen la Providencia nieguen también la oración» ${ }^{154}$.

La providencia en general y, sobre todo, la providencia especial en rela-

154. García Montaño, G., La eficacia de la oración impetratoria según San Agustín, Augustinus, $42-43$ (1966), 241. 
ción al hombre, providencia que todo lo dispone para el bien de los que aman a Dios, es el punto de apoyo en el que Agustín basa su doctrina sobre la eficacia de la oración. $\mathrm{Y}$, a la verdad, ningún otro apoyo puede presentarse con tanta garantía. Y ello es así, porque el amor es lo que está a la base de tal providencia. Agustín se hace eco de estos pensamientos, al comentar, como él solo lo sabe hacer, la misiva que Marta y María envían a Jesús con motivo de la enfermedad de su hermano Lázaro. «Enviaron a decirle...: ¿Qué es lo que le enviaron a decir sus hermanas? 'Señor, aquel a quien amas está enfermo'. No le dijeron que viniese, porque al amante le bastaba la noticia... No se atrevieron a decirle: Ven y sánalo; ni tampoco osaron decirle: Mándalo desde ahí y surtirá efecto aquí... Solamente dijeron: 'Señor, aquel a quien amas está enfermo'. Basta con que lo sepas, pues no abandonas a los que amas» ${ }^{155}$. Así es. Dios no abandona a los que ama. El amor providente de Dios es nuestra esperanza, nuestra seguridad. En él se apoya la seguridad de que nuestra oración es escuchada, aunque, en ocasiones, no se palpen los efectos inmediatos. Hasta se puede dar el caso que el Señor no nos oiga, porque son otros sus designios providenciales sobre nosotros. Agustín recuerda al respecto, y lo hace con suma admiración, el caso de Pablo. «El Dios propicio no da a muchos lo que quieren, para dar lo que les es útil. Es el caso de Pablo, cuando habla del acicate de la carne, ángel de Satanás, por el que es abofeteado, para que la magnitud de las revelaciones no le llenen de soberbia. El Apóstol ha pedido a Dios por tres veces que se aparte de él tal azote. Y el Señor le ha dicho: 'te basta mi gracia, pues la virtud se perfecciona en la enfermedad' (2 Cor 12,7)» ${ }^{156}$. Pablo no recibe ciertamente lo que pide. Pero recibe una gracia tan abundante que le permite hacer frente a todas las dificultades por las que está pasando. $\mathrm{El}$ caso paulino afianza la convicción agustiniana sobre la eficacia de la oración. Una convicción que tiene su raíz más profunda en el misterio insondable de una providencia, que se preocupa del hombre con inquietud maternal. «¿Acaso olvida una mujer a su niño de pecho, sin compadecerse del hijo de sus entrañas? Pues aunque ésas llegasen a olvidar, yo no te olvido» (Is 49,15). El amor providente de Dios empuja a Agustín y le hace exclamar: «En efecto, (Dios) no hace y abandona, ya que no se preocupó solamente de hacer, sin preocuparse de custodiar. Imploremos ante el Señor que nos hizo. Por tanto, quien nos hizo antes que se lo pidiéramos, ¿abandonará, cuando se lo pidamos? La Escritura, previendo que el hombre podría poner en duda el ser escuchado, cuando reza, lo amonesta diciendo: 'Imploremos ante el Señor que nos

155. San Agustín, In Jo. 49,5.

156. ID., De unit. Eccl. 49. 
hizo'. Sí, el Señor escucha a los que hizo; sí, el Señor tiene que cuidarse de quienes hizo" ${ }^{157}$.

Se hacía antes referencia a una providencia especial respecto al hombre por parte de Dios. Ella ciertamente existe desde el mismo hecho de la creación en virtud del lugar de excepción que el hombre ocupa en el marco de la misma. Para tomar nota del hecho no hace falta más que abrir las primeras páginas de la Sagrada Escritura. Dicha providencia especial adquiere caracteres muy particulares, cuando se tiene en cuenta el misterio de la redención. Dios, en verdad, crea al hombre de forma admirable, pero lo redime de forma más admirable aún. Así se expresa la Liturgia. Si el amor estaba tan presente en la creación, lo está mucho más vivo en el misterio de la redención. «Tanto amó Dios al mundo que le dio a su Hijo único, para que todo el que crea en él no perezca, sino que tenga la vida eterna» (Jn 3,16$)$. Por Jesús y en Jesús Dios ha entrado tanto en la historia del hombre que se ha hecho uno de la familia humana, asumiendo y viviendo las alternativas del mismo acontecer humano. La forma concreta de este misterio redentor es de tal magnitud que hace exclamar a Pablo: «El que no perdonó ni a su propio Hijo, antes bien le entregó por todos nosotros, ¿cómo no nos dará con él graciosamente todas las cosas?» (Rom 8,32). Recordando tales hechos, Agustín exclama inflamado: «¡Cómo nos amaste, Padre bueno, que no perdonaste a tu Hijo único, sino que lo entregaste por nosotros pecadores! ¿Cómo nos has amado, precisamente a nosotros, por quienes él no consideró usurpación ser igual a ti y por quienes se hizo obediente hasta la muerte de cruz, siendo el único libre entre los muertos, con poder para entregar su vida y poder para volver a recobrarla! Por nosotros se hizo vencedor y víctima ante tus ojos. $\mathrm{Y}$ es vencedor precisamente por ser víctima. Por nosotros se ha hecho en tu presencia sacerdote y sacrificio. Es sacerdote en cuanto que es sacrificio. De esclavos nos ha hecho hijos para ti, naciendo de ti y sirviéndonos a nosotros» ${ }^{158}$.

Un amor así, llevado a tales extremos, no puede anularse por nada. Y un amor así es la mejor garantía de que Dios escucha los gritos de sus hijos. El mismo Evangelio nos recuerda cómo se comporta nuestro Padre Dios en relación a las oraciones de sus hijos. «Si, pues, vosotros, siendo malos, sabéis dar cosas buenas a vuestros hijos, cuánto más vuestro Padre, que está en los cielos, dará cosas buenas a los que se las piden» (Mt 7,11).

El Evangelio nos recuerda la paternidad de Dios. Es un dato a tener muy en cuenta. En efecto, la relación del hombre con Dios ha cambiado de signo como consecuencia de la venida del Hijo de Dios en carne humana. Él, el Hijo, nos ha concedido la gracia inefable de ser los hijos. «Al llegar la plenitud

157. ID., Serm. 26,1. CCL. 41, 348-349.

158. ID., Conf. 10,43,69. 
de los tiempos, envió Dios a su Hijo, nacido de mujer, nacido bajo la ley, y para que recibiéramos la filiación adoptiva» (Gal 4, 4-5). Este misterio de identidad entre Jesús y los hombres constituye tema privilegiado para la reflexión teológica de Agustín. Se puede decir sin peligro de equivocarse que Agustín es el teólogo que más y mejor ha profundizado en la doctrina paulina del cuerpo de Cristo. A través de esta imagen el Apóstol ha intentado expresar la relación profunda que existe entre Cristo-cabeza e iglesia-cuerpo. Agustín ha inmortalizado una fórmula feliz para traducir la relación íntima que hay entre Cristo y su Iglesia. A esta realidad la llama él «el Cristo total». «Por cuanto he podido vislumbrar en las páginas sagradas, hermanos, a nuestro Señor Jesucristo se le considera y nombra de tres modos, cuando es anunciado tanto en la ley y los profetas, como en las cartas apostólicas o en los hechos merecedores de fe que conocemos por el Evangelio. El primero de ellos, anterior a la asunción de la carne, es en cuanto Dios y en referencia a la divinidad, igual y coeterna a la del Padre. El segundo se refiere al momento en que ha asumido ya la carne, en cuanto se lee y se entiende que el mismo que es Dios es hombre y el mismo que es hombre es Dios, según una cierta propiedad de su excelsitud, por la que no se equipara a los restantes hombres, sino que es mediador y cabeza de la Iglesia. El tercer modo es el que en cierta manera denominamos Cristo total, en la plenitud de su Iglesia, es decir, cabeza y cuerpo, según la plenitud de cierto varón perfecto, de quien somos miembros cada uno en particular» ${ }^{159}$.

Este tercer modo llama profundamente la atención de Agustín y le brinda la oportunidad de formular hermosos pensamientos teológicos $\mathrm{y}$, sobre todo, de elaborar una doctrina ascético-mística verdaderamente admirable. «Felicitémonos, pues, a nosotros mismos y seamos agradecidos; se nos ha hecho llegar a ser no sólo cristianos, sino Cristo mismo. ¿Os dais cuenta, hermanos, comprendéis lo que Dios nos ha hecho? Es para que os llenéis de admiración y de alegría. Se nos ha hecho llegar a ser Cristo mismo. Porque, si él es la cabeza y nosotros somos los miembros, todo el hombre es él y nosotros... La plenitud de Cristo o todo el Cristo es la cabeza y los miembros. ¿Cuál es la cabeza y cuáles son los miembros? Cristo y la Iglesia» ${ }^{160}$. Con acentos extáticos, Agustín, entusiasmado por el misterio del Cristo total, se dirige a los creyentes y les exhorta: «Amad lo que vais a ser. Vais a ser hijos de Dios, e hijos de adopción. Eso se os otorgará y se os concederá gratuitamente. Vueștra participación será tanto más abundante y generosa cuanto mayor sea vuestra gratitud hacia a aquel de quien la habéis recibido. Suspirad por él, que conoce quienes

159. ID., Serm. 341,1,1; ML. 39,1493.

160. ID., In Jo. Ev. tr. 21,8, ML. 35,1568. 
son los suyos. No tendrá inconveniente en contaros entre los que él sabe son suyos si, invocando el nombre del Señor, os apartáis de la injusticia. Tenéis, o habéis tenido, en este mundo, padres carnales que os engendraron para la fatiga, el sufrimiento y la muerte; pero, pensando en una orfandad aportadora de mayor felicidad, cada uno de vosotros puede decir de ellos: 'mi padre y mi madre me abandonaron'. Reconoce, ;oh cristiano!, a aquel otro padre que, al abandonarte ellos, te recogió desde el seno de tu madre, y a quien cierto creyente dice con verdad: 'tú eres mi protector desde el seno de mi madre'. El padre es Dios; la madre, la iglesia» ${ }^{161}$. En verdad, ningún otro fundamento puede aportar al creyente una espiritualidad tan solidaria como la doctrina de Agustín sobre el Cristo total. Quien se cierra al amor solidario desconoce lo más nuclear del mensaje cristiano, que es la doctrina sobre el Cristo total. «Para esto nos amó, pues, para que nos amemos los unos a los otros; amándonos mutuamente nos concede que podamos nosotros ligarnos entre nosotros con un amor mutuo y, unidos nuestros miembros con vínculo tan dulce, podamos ser cuerpo de tan gran cabeza» ${ }^{162}$.

El Cristo total, misterio viviente de la unión entre Cristo-cabeza e iglesiacuerpo, tiene para Agustín su forma concreta de oración. Cristo-cabeza ora con nosotros, ora por nosotros y ora en nosotros. $\mathrm{Su}$ oración trasciende el marco de lo puramente personal. Cuando ora la iglesia, ora también Cristo con ella. Agustín ha descubierto este nuevo misterio reflexionando sobre diversas formas de oración en los Salmos. Las fórmulas orantes de éstos son, a veces, de tal envergadura que recubren el misterio de unión entre Cristo y la Iglesia. «Puesto que el Cristo total es cabeza y cuerpo, por eso es preciso que oigamos su voz en todos los salmos, para escuchar al mismo tiempo la voz de su cuerpo. No quiso hablar aisladamente, porque no quiso estar separado, cuando dice: 'he aquí que yo estoy con vosotros hasta la consumación de los siglos' (Mt 28,20). Si, pues, está con nosotros, habla en nosotros, habla de nosotros, habla por nosotros; $y$, por eso, hablamos verdad, porque hablamos en él. Si quisiéramos hablar en nosotros y desde nosotros, permaneceríamos en la mentira» ${ }^{163}$. Agustín está tan empapado del misterio del Cristo total que lo descubre con una facilidad asombrosa. Lo descubre y lo expresa y lo admira. «Ningún don mayor puede Dios conceder a los hombres que el que su Verbo, por el que hizo todas las cosas, se hiciera su cabeza y los considerara como sus miembros, a fin de ser Hijo de Dios e hijo del hombre, Dios con el Padre y hombre con los hombres. Y así, cuando hablamos a Dios orando, no separemos de ahí al Hijo; y, cuando ruega el cuerpo del Hijo, no aparte de sí a su ca-

161. ID., Serm. 216,8 .

162. ID., In Jo. Ev. tract. 65,2.

163. ID., En. in Ps. 56,1. 
beza. Sea, pues, el mismo nuestro Señor Jesucristo, salvador de su cuerpo, quien ore por nosotros, ore en nosotros y sea implorado por nosotros. Ora por nosotros como sacerdote. Ora en nosotros como nuestra cábeza; es implorado por nosotros como nuestro Dios. Discernamos, pues, en él nuestras voces y su voz en nosotros» ${ }^{164}$.

¡Cristo ora por nosotros! ¡Cristo ora en nosotros! ¡Cristo ora con nosotros! No se trata de un dato anecdótico. Es la consecuencia teológica de una de las realidades más fabulosas y sugestivas de la revelación. Cristo es nuestra cabeza. Nosotros somos sus miembros. Entre ella y nosotros surca una corriente de vida igual que, procediendo de la cabeza, alienta y vivifica a todos los miembros. Identidad de vida e identidad de acción. Este hecho habla por sí solo de la eficacia de la oración. Jesús manifiesta en cierta ocasión que el Padre siempre le escucha. (Cf. Jn 11,42). Y Jesús, en fuerza de su vinculación viviente a la iglesia, ora en nosotros, con nosotros y por nosotros. Por tanto, la oración, que se hace en el nombre de Jesús, en estrecha vinculación a Jesús, tiene una eficacia segura. Naturalmente que en dicha oración no todo tiene el mismo rango. Hay jerarquía de valores. En el huerto Jesús suplica al Padre que, si es posible, pase de él el cáliz de la pasión. La petición es correcta. Sin embargo, los planes de la divina Providencia son otros. Jesús deberá aceptar la pasión para llevar así a buen término la redención de los hombres. El bien inmediato de Jesús está en este momento vinculado al bien de la humanidad con la que se ha identificado. La gloria del Padre exige ahora una respuesta que repugnaba a la condición humana de Jesús. Así sucede también en nuestra oración. "La eficacia está prometida única y exclusivamente a la oración en que se pida lo que en realidad conduce directamente a la vida eterna y sólo la petición que tenga como objeto esta finalidad puede llamarse verdaderamente oración genuina» ${ }^{165}$.

Se puede decir que, para Agustín, la eficacia de la oración está garantizada, si en ella se mantiene la fidelidad al orden providente. La providencia de Dios lo ha dispuesto todo para que el hombre, cumplida su misión en la tierra, alcance la vida eterna. Todo hay que verlo, según Agustín, desde esa óptica. Cuando no se adopta ese punto de vista, la eficacia de la oración queda de hecho comprometida. Agustín afirma eso constantemente. «Es necesario distinguir cosa de cosas. Las tocantes a la vida temporal Dios sabe que a veces aprovechan y a veces dañan; $y$, cuando Dios sabe que son perjudiciales, niégaselas a los suyos que las desean y las piden, cual no accede el médico a cuanto pide el enfermo, y por el amor le niega cuanto le otorgara de no amarle». ${ }^{166}$. «Con-

164. ID., En. in Ps. 85,1 .

165. García Montaño, G., La ineficacia de la oración según San Agustín, Augustinus, 44 (1966) 346

166. San Agustín, Serm. Wilm., 12,4, in 'Misce. Agost.' I, 107. 
forme a esto, debemos entender que, si Dios no asiente a nuestro querer, con todo, nos concede la salud. ¿Qué sucedería si pidieses lo que te perjudica, conociendo el médico que es nocivo? No te desoye el médico cuando, por ejemplo, pides agua fría y, si te es saludable, al instante te la da, y, si no lo es, te la niega. ¿No te oyó porque se opuso a tu voluntad? Al contrario, te oyó, mirando por tu salud» ${ }^{167}$.

En realidad para Agustín la oración es siempre eficaz aun en el caso en que no se conceda lo que se pide materialmente. Esta primera frustración queda compensada, grandemente compensada, cuando se la contempla desde la óptica del plan de salvación. Jesús es «Salvador, no sólo cuando hace lo que pedimos, sino también cuando no lo hace. $\mathrm{Al}$ no hacer lo que se pide contra la salud, se muestra más Salvador...» ${ }^{168}$.

Después de un largo recorrido pongo aquí punto final. El tema es ciertamente apasionante y delicado. Y aún más: es de capital importancia para todo aquel que, como creyente, intenta dar una respuesta digna a su llamada. Llamados a ser santos e irreprochables en la presencia de Dios (Cf. Ef 1,4b), los creyentes deben tomar conciencia de que eso no es posible sin una praxis constante y profunda de la oración. La oración no es un asunto de más o menos importancia en la vida del creyente. Orar es una necesidad que nace de la misma vocación cristiana. Creo que el magisterio de Agustín sobre el particular es particularmente luminoso. Quien quiera vivir el mensaje de su conversión, deberá tomar nota de lo que él dice sobre la oración. No basta con escucharle. Es preciso seguirle. Por ello, nada mejor que terminar con una exhortación suya a la oración: «Por tanto, hermanos, os decimos que oréis cuanto podáis. Abundan los males y Dios los quiso. ¡Ojalá no abundaran los malos y no abundarían lo males! 'Malos tiempos, tiempos fatigosos', así dicen los hombres. Vivamos bien y serán buenos los tiempos. Los tiempos somos nosotros; cuales somos nosotros, así son los tiempos» ${ }^{169}$.

BENITO DOMÍNGUEZ SÁNCHEZ

Estudio Teológico Agustiniano

Valladolid

167. ID., In Epist. ad P., 6.8 .

168. ID., In Jo. tract. 73,3.

169. ID., Serm. 80,8. 